\title{
The Purinergic System as a Pharmacological Target for the Treatment of Immune-Mediated Inflammatory Diseases
}

\author{
Luca Antonioli, Corrado Blandizzi, Pál Pacher, and György Haskó
}

Department of Clinical and Experimental Medicine, University of Pisa, Pisa, Italy (L.A., C.B.); Laboratory of Cardiovascular Physiology and Tissue Injury, National Institutes of Health, National Institute on Alcohol Abuse and Alcoholism, Bethesda, Maryland (P.P.); and Department of Anesthesiology, Columbia University, New York, New York (G.H.)

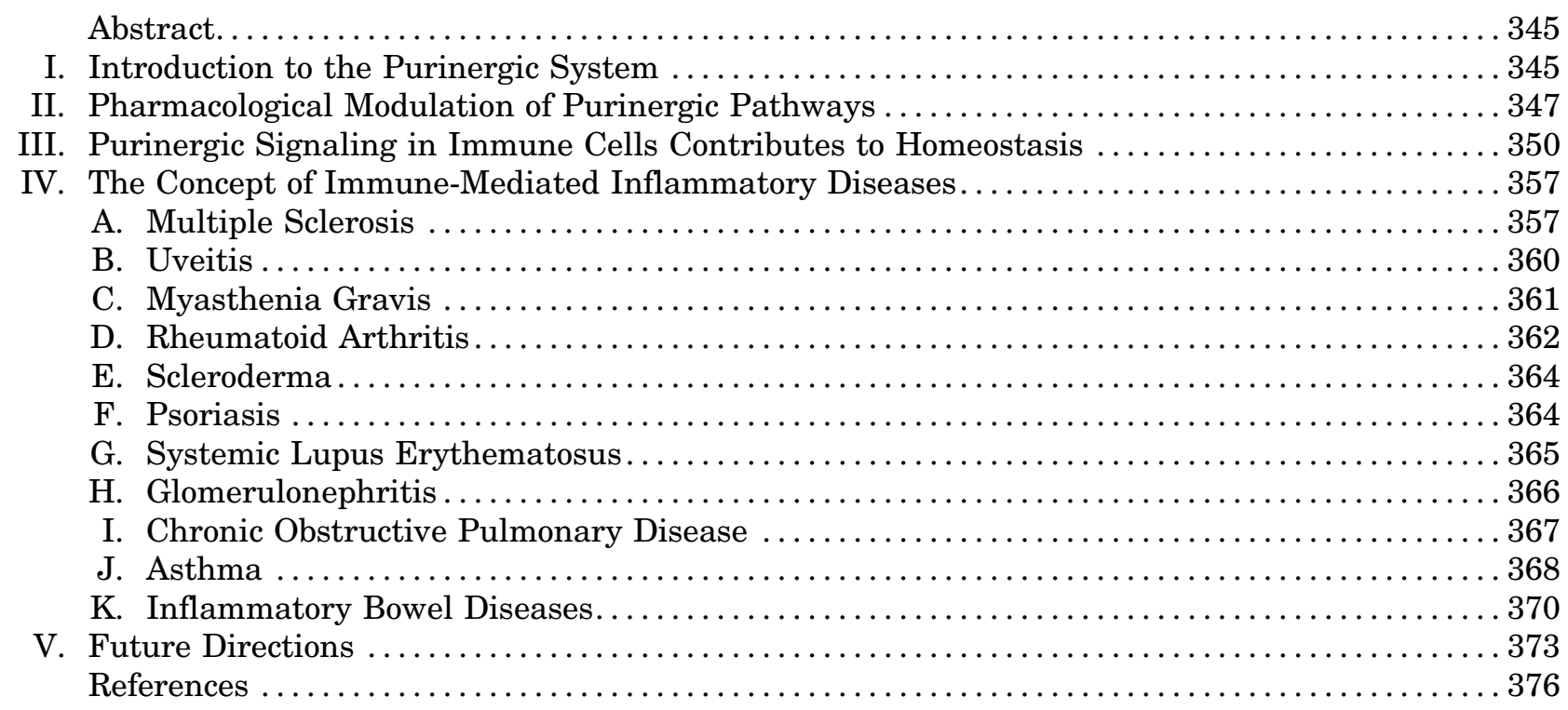

\begin{abstract}
Immune-mediated inflammatory diseases (IMIDs) encompass a wide range of seemingly unrelated conditions, such as multiple sclerosis, rheumatoid arthritis, psoriasis, inflammatory bowel diseases, asthma, chronic obstructive pulmonary disease, and systemic lupus erythematosus. Despite differing etiologies, these diseases share common inflammatory pathways, which lead to damage in primary target organs and frequently to a plethora of systemic effects as well. The purinergic signaling complex comprising extracellular nucleotides and nucleosides and their receptors, the P2 and P1
\end{abstract}

purinergic receptors, respectively, as well as catabolic enzymes and nucleoside transporters is a major regulatory system in the body. The purinergic signaling complex can regulate the development and course of IMIDs. Here we provide a comprehensive review on the role of purinergic signaling in controlling immunity, inflammation, and organ function in IMIDs. In addition, we discuss the possible therapeutic applications of drugs acting on purinergic pathways, which have been entering clinical development, to manage patients suffering from IMIDs.

\section{Introduction to the Purinergic System}

The purinergic system is an intricate jigsaw puzzle of mediators, receptors, transporters, and synthetic and catabolic enzymes to which scientific research continues to add new pieces on a daily basis (Antonioli et al., 2013b; Burnstock, 2016, 2018).

Address correspondence to: Dr. György Haskó, Department of Anesthesiology, Columbia University, 622 W. 168th St., P\&S Box 46, New York, NY 10032. E-mail: gh2503@cumc.columbia.edu

This work was supported by National Institutes of Health National Institute of General Medical Sciences Grant R01GM066189 and National Institute of Diabetes and Digestive and Kidney Diseases Grant R01DK113790 (both to G.H.).

Disclosure: G.H. has stock in Purine Pharmaceuticals, Inc.

https://doi.org/10.1124/pr.117.014878. 
Purinergic signaling is initiated by the release of nucleotides and nucleosides into the extracellular space through volume regulated anion channels, maxi-anion channels, transporters, connexins, and pannexins (Taruno, 2018), as well as through exocytotic pathways and membrane damage (Fig. 1) (Antonioli et al., 2013b). Following their release into the extracellular space, the nucleotides and nucleosides bind to specific receptors located on the surface of the target cell membrane. The cellular signals triggered by nucleotides, including ATP, ADP, UTP, UDP, and UDP-glucose, are mediated by the engagement of $\mathrm{P} 2$ receptor subtypes, which are classified into ionotropic $\mathrm{P} 2 \mathrm{X}\left(\mathrm{P}_{2} \mathrm{X}_{1-7}\right)$ and metabotropic P2Y (P2Y $1,2,4,6,11-14$ ) receptors (Fig. 1) (Antonioli et al., 2013b).

$\mathrm{P} 2 \mathrm{X}$ receptors have a trimeric topology with two transmembrane domains, gating primarily $\mathrm{Na}^{+}, \mathrm{K}^{+}$, and $\mathrm{Ca}^{2+}$ and, occasionally $\mathrm{Cl}^{-}$(Pawson et al., 2014). Activation of the $\mathrm{G}_{\mathrm{q} / 11^{-}}$-coupled $\mathrm{P} 2 \mathrm{Y}_{1,2,4,6}$ and $\mathrm{P} 2 \mathrm{Y}_{11}$ receptors leads to the stimulation of phospholipase $\mathrm{C}$, which initiates the production of inositol- $(1,4,5)$ trisphosphate and diacylglycerol (Franke et al., 2006). Inositol-(1,4,5)-trisphosphate increases intracellular $\mathrm{Ca}^{2+}$ levels and diacylglycerol stimulates protein kinase $\mathrm{C}$ (Franke et al., 2006). In addition, $\mathrm{P} \mathrm{Y}_{11}$ receptor activation can stimulate whereas $\mathrm{P}_{2} \mathrm{Y}_{12,13}$ receptor activation can inhibit adenylate cyclase (Franke et al., 2006).

The most important extracellular nucleosides are adenosine and inosine, and they signal through G proteincoupled $\mathrm{P} 1$ or adenosine receptors. They are classified into $A_{1}, A_{2 A}, A_{2 B}$, and $A_{3}$ (Antonioli et al., 2019) (Fig. 1). $A_{1}$ and $A_{3}$ receptors are coupled to $G_{i}, G_{q}$, and $G_{o}$ proteins. $A_{2 A}$ and $A_{2 B}$ receptors activate adenylate cyclase via $G_{s}$ or $\mathrm{G}_{\text {olf }}$ (Antonioli et al., 2019). The engagement of $A_{2 B}$ receptors can also activate phospholipase $\mathrm{C}$ via $\mathrm{G}_{\mathrm{q}}$ (Antonioli et al., 2013a, 2019).

Purinergic signaling through receptors is regulated by the availability of extracellular purines and tightly controlled by nucleotidases/phosphatases and kinases. In this regard, the cell surface ecto-enzyme axis, comprising the phosphatases CD39 and CD73, is the major mediator of the degradation of extracellular ATP, ADP, and AMP into adenosine (Antonioli et al., 2013c) (Fig. 1). In addition, the CD38-CD203a (ectonucleotide pyrophosphatase/ phosphodiesterase 3) enzyme axis on the cell surface, which operates independently or in synergy with the CD39/CD73 pathway, also contributes to the metabolism of extracellular purines (Morra et al., 1998; Bahri et al., 2012). In particular, CD38 catalyzes the synthesis of cyclic ADP-ribose from nicotinamide adenine dinucleotide $\left(\mathrm{NAD}^{+}\right)$, and mediates the hydrolysis of cyclic ADPribose to ADP-ribose (Quarona et al., 2013; Hasko et al., 2018) (Fig. 1) The pyrophosphatase/phosphodiesterase CD203a is capable of hydrolyzing both $\mathrm{NAD}^{+}$, ADPribose and also ATP to produce AMP, which can then be degraded into adenosine by CD73 (Quarona et al., 2013; Horenstein et al., 2016; Hasko et al., 2018) (Fig. 1).

Most cell types in the body are endowed with nucleoside transporters, which can transport purines across the cell membrane from the intra- to the extracellular space and vice versa, thus contributing to both the initiation and termination of purinergic signaling (Fredholm et al., 2011; Pastor-Anglada et al., 2018) (Fig. 1). Based on their molecular and functional characteristics, nucleoside transporters are classified into 1) equilibrative nucleoside transporters (ENTs; ENT1, ENT2, ENT3, and ENT4), which carry nucleosides across cell membranes along their concentration gradients (Young, 2016; Boswell-Casteel and Hays, 2017), and 2) concentrative nucleoside transporters (CNTs; CNT1, CNT2, and CNT3), which mediate the cellular uptake of nucleosides against their concentration gradient (Young, 2016). Once the cell takes up adenosine, it is quickly phosphorylated to AMP via adenosine kinase (Antonioli et al., 2010a; Camici et al., 2018). In parallel, the metabolizing enzyme adenosine deaminase converts adenosine into inosine both intra- and extracellularly (Fig. 1) (Antonioli et al., 2012). Intracellular inosine is ultimately converted into the stable end product uric acid by xanthine oxidase (Fig. 1).

Purinergic pathways have long been known to contribute to homeostasis in healthy organisms through regulating several organ systems, which include the cardiovascular, renal, gastrointestinal, and central nervous systems (Antonioli et al., 2013b; Bele and Fabbretti, 2015; Burnstock, 2017). It has also been

\footnotetext{
ABBREVIATIONS: ADA, adenosine deaminase; SCH 442416, 5-amino-7-(3-(4-methoxyphenyl)propyl)-2-(2 furyl)pyrazolo[4,3-e]-1,2,4-triazolo[1,5-c] pyrimidine; AZD9056, $\mathrm{N}$-(1-adamantylmethyl)-2-chloro-5-[3-(3-hydroxypropylamino)propyl]benzamide; BAL, bronchoalveolar lavage; BAY 60-6583, 2-[[6-amino-3,5-dicyano-4-[4-(cyclopropylmethoxy)phenyl]-2-pyridinyl]thio]-acetamide; CD38, cyclic ADP ribose hydrolase; CD39, ectonucleoside triphosphate diphosphohydrolase 1; CD73, ecto-5' nucleotidase; CNT, concentrative nucleoside transporter; COPD, chronic obstructive pulmonary disease; DC, dendritic cell; DSS, dextran sulfate sodium; EAE, experimental autoimmune encephalomyelitis; EAMG, experimental autoimmune myasthenia gravis; EAU, experimental autoimmune uveitis; ENT, equilibrative nucleoside transporter; IBD, inflammatory bowel disease; IB-MECA, 1-deoxy-1-[6-[((3-iodophenyl)methyl]amino]-9H-purin-9-yl]- $N$-methyl-3-amino-1-(6-(((5-chloro-2-((3-methyl5 -isoxazolyl)methoxy)phenyl)methyl)amino)-9H-purin-9-yl)-1,3-dideoxy- $N$-methyl; IFN, interferon; IMID, immune-mediated inflammatory disease; KO, knockout; MG, myasthenia gravis; MOG, myelin oligodendrocyte glycoprotein; MS, multiple sclerosis; $\mathrm{NAD}^{+}$, nicotinamide adenine dinucleotide; NECA, 1-(6-amino-9H-purin-9-yl)-1-deoxy- $N$-ethyl-3-amino-1-(6-(((5-chloro-2-((3-methyl-5-isoxazolyl)methoxy)phenyl)methyl)amino)9H-purin-9-yl)-1,3-dideoxy- $N$-methyl; NF-кB, nuclear factor kappa-light-chain-enhancer of activated B cells; NK, natural killer; OVA, ovalbumin; oxATP, oxidized ATP; RA, rheumatoid arthritis; SLE, systemic lupus erythematosus; TNBS, trinitrobenzenesulfonic acid; TNF, tumor necrosis factor.
} 


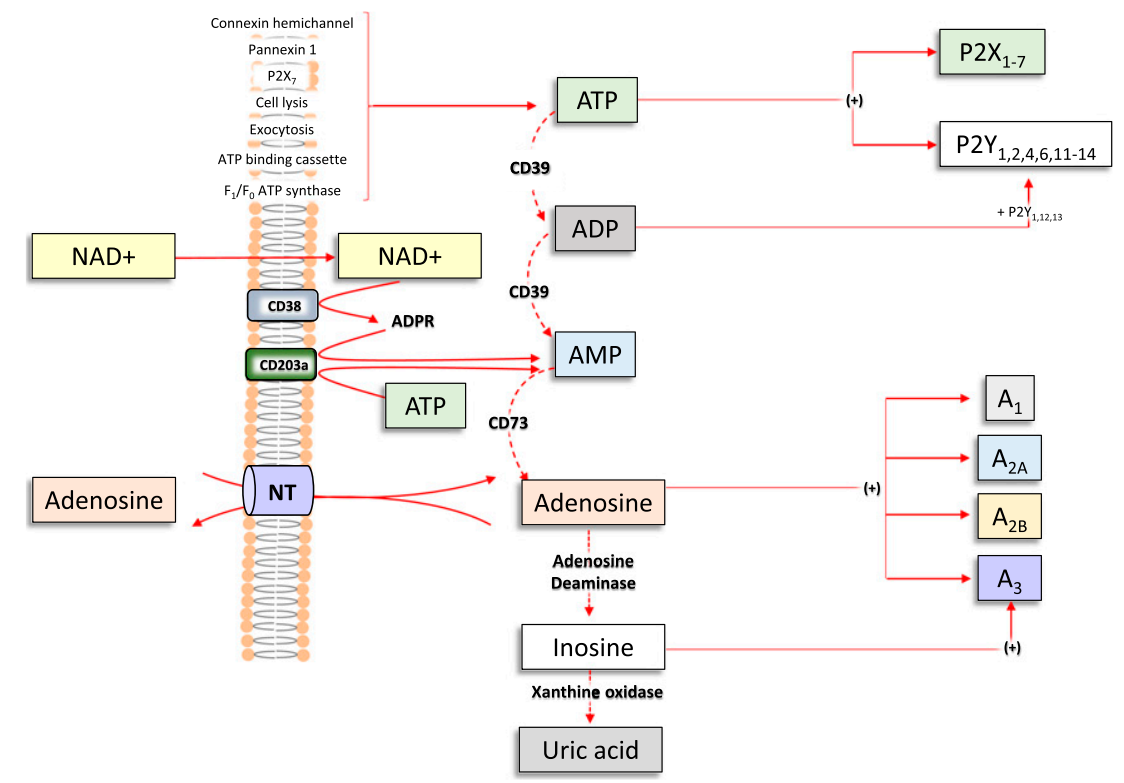

Fig. 1. Schematic diagram of the purinergic signaling complex. Once released into the extracellular environment, through channels or other extrusion systems, ATP exerts its extracellular effects by binding P2 receptors (P2X and P2Y). ATP is degraded by the nucleotidases CD39 and CD73, leading to the sequential dephosphorylation of ATP to ADP and AMP and subsequent generation of the bioactive metabolite adenosine, which activates P1 ( $\mathrm{A}_{1}$, $\mathrm{A}_{2 \mathrm{~A}}, \mathrm{~A}_{2 \mathrm{~B}}$, and $\mathrm{A}_{3}$ ) receptors. The CD38-CD203a (ectonucleotide pyrophosphatase/phosphodiesterase 3) enzyme axis on the cell surface, operating independently or in synergy with the conventional CD39/CD73 pathway, also contributes to the generation of the adenosine. Several cell types are endowed with nucleoside transporters (NT) and adenosine deaminase, which mediate the uptake or deamination of extracellular adenosine, respectively, thus actively participating in the termination of adenosine signaling. ADP, adenosine diphosphate; ADPR, ADP-ribose; AMP, adenosine monophosphate; ATP, adenosine triphosphate; $\mathrm{NAD}^{+}$, nicotinamide adenine dinucleotide.

known for almost a century that purinergic signaling is especially important as a regulator of organ function during and following the disruption of homeostasis, which is due to the fact that extracellular purines accumulate in response to homeostasis-disrupting factors, such as tissue injury and changes in the extracellular milieu (e.g., hypoxia, acidosis, ion balance disturbances, and alterations in hormones and neurotransmitters). In the last few decades, the immune system has emerged as a major target of purinergic signaling in both homeostasis and disease. In the present review we will first discuss the role of the purinergic system in regulating immune cell function in homeostasis. Building on this understanding of how purinergic signaling regulates immune function in a healthy organ system, we will then provide an overview about the role of purinergic signaling in sustaining and or controlling immune-mediated inflammatory diseases (IMIDs) and the underlying immune and inflammatory pathways. Finally, we will highlight the possible therapeutic applications of drugs acting on the purinergic machinery in managing patients suffering from IMIDs.

\section{Pharmacological Modulation of Purinergic Pathways}

Growing efforts are being focused on the design and synthesis of novel pharmacological entities comprising selective agonists and antagonists for ATP and adenosine receptor subtypes (see Table 1), as well as on tools able to regulate the endogenous levels of purines through interfering with the function of synthetic/catabolic enzymes and transporters (see Table 2).

Direct receptor-targeting efforts comprise the development of competitive agonists or antagonists that are able to interact, with increasing selectivity, with the main binding sites of the receptors (orthosteric drugs). Drug design is aided by the ever increasing number of resolved crystal structures of the various purinergic receptors, enzymes, and transporters. Biased agonism is an emerging concept in the pharmacology of G-proteincoupled receptor signaling, which provides for the possibility that a given ligand is able to preferentially activate one (or some) of the possible signaling pathways (Pupo et al., 2016). This is an intriguing point, since if different processes downstream of the same receptor are involved in a pathologic condition, biased ligands would have the potential to selectively activate the therapeutically relevant pathway sparing other signaling, thus limiting adverse events. This is a relevant aspect especially in the pharmacology of the purinergic system, due to the wide distribution throughout the body of $\mathrm{P} 1$ and $\mathrm{P} 2$ receptors and their involvement in modulating several physiologic functions. In addition, there are further questions that need to be answered during the drug design process. For example, do potential antagonists operate as neutral antagonists or are they also inverse agonists? Would it be possible to develop peripheral or central nervous system-penetrable agonists/antagonists?

In addition, as the wide distribution of purinergic receptors throughout the body increases the risk of 
TABLE 1

Selective ligands for purinergic receptors

\begin{tabular}{|c|c|c|c|c|}
\hline Receptor & Signaling & Agonists & Antagonists & Allosteric modulators \\
\hline \multicolumn{5}{|c|}{$\mathrm{P} 2$ receptors } \\
\hline $\mathrm{P}_{2} \mathrm{X}_{1}$ & $\begin{array}{l}\text { ligand-gated ion } \\
\text { channel }\end{array}$ & $\begin{array}{l}\text { 2-MeSATP, L- } \beta, \gamma \text {-meATP, } \\
\alpha, \beta \text {-meATP, BzATP, HT-AMP, } \\
\text { PAPET-ATP, } \text { Ap }_{5} \text { A, CTP }\end{array}$ & $\begin{array}{l}\text { TNP-ATP, Ip } 5 \text { I, NF023, NF449, NF } \\
\text { 279, PPNDS, Ro 0437626, } \\
\text { IsoPPADS, MRS2159, phenol red, } \\
\text { suramin }\end{array}$ & - \\
\hline $\mathrm{P} 2 \mathrm{X}_{2}$ & $\begin{array}{l}\text { ligand-gated ion } \\
\text { channel }\end{array}$ & - & $\begin{array}{l}\text { NF770, NF778, NF 279, PSB-10211, } \\
\text { PPADS, RB-2, suramin, TNP-ATP }\end{array}$ & - \\
\hline $\mathrm{P}_{2} \mathrm{X}_{3}$ & $\begin{array}{l}\text { ligand-gated ion } \\
\text { channel }\end{array}$ & $\begin{array}{l}\text { 2-MeSATP, } \alpha, \beta \text {-meATP, BzATP, } \\
\text { D- } \beta, \gamma \text {-Me-ATP, } 2 \text {-MeSATP, } \\
\text { HT-AMP, PAPET-ATP, Ap }{ }_{5} \mathrm{~A}\end{array}$ & $\begin{array}{l}\text { TNP-ATP, A317491, AF-906, AF-219, } \\
\text { RO3, NF110, spinorphin }\end{array}$ & - \\
\hline $\mathrm{P}_{2} \mathrm{X}_{4}$ & $\begin{array}{l}\text { ligand-gated ion } \\
\text { channel }\end{array}$ & - & $\begin{array}{l}\text { BX-430, BBG, phenolphtalein, TNP- } \\
\text { ATP 5-BDBD, PSB-12062, } \\
\text { paroxetine }\end{array}$ & Ivermectin (positive) \\
\hline $\mathrm{P}^{2} \mathrm{X}_{5}$ & $\begin{array}{l}\text { ligand-gated ion } \\
\text { channel }\end{array}$ & - & - & - \\
\hline $\mathrm{P}^{2} \mathrm{X}_{6}$ & $\begin{array}{l}\text { ligand-gated ion } \\
\text { channel }\end{array}$ & - & - & - \\
\hline $\mathrm{P} 2 \mathrm{X}_{7}$ & $\begin{array}{l}\text { ligand-gated ion } \\
\text { channel }\end{array}$ & - & $\begin{array}{l}\text { Brilliant Blue G, A804598, A839977, } \\
\text { decavanadate, KN62, KN-04, BBG, } \\
\text { oxidized-ATP, A740003, A438079, } \\
\text { AZ10606110 }\end{array}$ & $\begin{array}{l}\text { AZ10606120 (negative), GW791343 } \\
\text { (positive), GW791343 (negative), } \\
\text { chelerythrine (negative), } \\
\text { AZ11645373(negative) KN62 } \\
\text { (negative) Ivermectin (positive) }\end{array}$ \\
\hline $\mathrm{P}_{2} \mathrm{Y}_{1}$ & $\mathrm{G}_{\mathrm{q}}$ & $\begin{array}{l}2 \text {-Cl-ADP }(\alpha-\mathrm{BH} 3), 2-\mathrm{MeSADP} \\
\mathrm{ADP} \beta \mathrm{S}, \mathrm{MRS} 2365\end{array}$ & MRS2500, MRS2279, MRS2179, PIT & $\begin{array}{l}2,2^{\prime} \text {-pyrydilisatogen tosylate } \\
\text { (negative), BMS compound } \\
16 \text { (negative) }\end{array}$ \\
\hline $\mathrm{P}_{2} \mathrm{Y}_{2}$ & $\mathrm{G}_{\mathrm{q}}$ & $\begin{array}{l}\text { UTPgS, Ap4A, 2-thioUTP, MRS2698, } \\
\text { MRS2768, PSB1114 }\end{array}$ & - & - \\
\hline $\mathrm{P} 2 \mathrm{Y}_{4}$ & $\mathrm{G}_{\mathrm{q}}$ & $\begin{array}{l}\text { MRS4062, MRS2927, } \\
\text { (N)methanocarba UTP, UTP } \gamma \mathrm{S}\end{array}$ & PPADS, reactive blue- 2 , ATP & - \\
\hline $\mathrm{P} 2 \mathrm{Y}_{6}$ & $\mathrm{G}_{\mathrm{q}}$ & $\begin{array}{l}\text { UDP, 3-phenacyl UDP PSB0474, } \\
\text { MRS2693, MRS2957 }\end{array}$ & MRS2578, MRS2567 & - \\
\hline $\mathrm{P}_{2} \mathrm{Y}_{11}$ & $\mathrm{G}_{\mathrm{q}}$ & ATP $\gamma \mathrm{S}, \mathrm{NF} 546$, AR-C67085, NAD ${ }^{+}$ & NF157, NF340 & - \\
\hline $\mathrm{P}_{2} \mathrm{Y}_{12}$ & $\mathrm{G}_{\mathrm{i}}^{\mathrm{u}}$ & $2-\mathrm{MeSADP}, \mathrm{ADP} \beta \mathrm{S}$ & $\begin{array}{l}\text { PSB-0739, AR-C 66096, ATP, } \\
\text { AZD1283, ARL66096, cangrelor, } \\
\text { Ap } 4 \text { a, ticlopidine }^{\text {a }}\end{array}$ & \\
\hline $\mathrm{P}_{2} \mathrm{Y}_{13}$ & $\mathrm{G}_{\mathrm{i}}$ & 2-MeSADP, 2-MeSATP & MRS2211, MRS2603, cangrelor, $\mathrm{Ap}_{4} \mathrm{a}$ & \\
\hline $\mathrm{P}_{2} \mathrm{Y}_{14}$ & $\mathrm{G}_{\mathrm{i}}$ & $\begin{array}{l}\text { MRS2905, } \alpha \beta \text { methilen 2-thioUTP, } \\
\text { 2-thioUDP }\end{array}$ & PPTN & \\
\hline
\end{tabular}

adverse effects after orthosteric agonist administration, the development of allosteric modulators of purinergic receptors has represented another area of active research. By binding to sites different from the primary one for endogenous ligands, allosteric ligands act by modulating receptor conformation only in the presence of the endogenous agonist; that is, at sites of tissue distress (Antonioli et al., 2011, 2010b, 2014; Coddou et al., 2011; Goblyos and Ijzerman, 2011; Muller, 2015; De Marchi et al., 2016). The usefulness of this approach is underlined by studies showing that allosteric antagonists for $\mathrm{P}_{2} \mathrm{X}_{3}, \mathrm{P} 2 \mathrm{X}_{4}$, and $\mathrm{P} 2 \mathrm{X}_{7}$ had beneficial effects in preclinical models of joint inflammation and asthma (Ford and Undem, 2013).

In addition to the direct receptor-targeting ligands, increasing efforts have been focused on identifying novel pharmacological agents able to modulate the extracellular levels of endogenous purines through targeting catabolic enzymes, nucleoside transporters, and other release mechanisms (see Table 2 ). In addition, a number of anti-inflammatory agents currently used to treat IMIDs, such as cyclosporine (Neoral, Sandimmune, Gengraf), salicylates (aspirin), methotrexate (Trexall, Rasuvo, Otrexup), sulfasalazine (Azulfidine, Sulfazine,
Azulfidine EN-tabs), and the novel JAK-STAT inhibitor tofacitinib (Xeljanz, Xeljanz XR) have been shown to exert their beneficial effects by increasing extracellular adenosine levels (Morabito et al., 1998; Cronstein et al., 1999; Capecchi et al., 2005; Cronstein, 2006b; Koizumi et al., 2015).

MicroRNAs (miRNAs) are small noncoding RNAs that are approximately 20-25 nucleotides in length, which regulate the expression of multiple target genes through sequence-specific hybridization to the 3 '-untranslated region of messenger RNAs (Christopher et al., 2016). A number of pharmacological tools have been developed to target miRNA pathways (van Rooij and Kauppinen, 2014). Ferrari et al. (2016) have reviewed the available data on the modulatory role of miRNAs in regulating the expression of molecular components of the purinergic network as summarized in Table 3. For these reasons, therapies aimed at specifically modulating purinergic miRNAs could hopefully be introduced to treat IMIDs (Ferrari et al., 2016). At present, the main challenges, which remain to be addressed for developing miRNAbased therapeutics, are efficacious delivery to target tissues and cells, potential off-target effects and safety (Garzon et al., 2010). 
TABLE 1-Continued

\begin{tabular}{|c|c|c|c|c|}
\hline Receptor & Signaling & Agonists & Antagonists & Allosteric modulators \\
\hline \multicolumn{5}{|c|}{$\mathrm{P} 1$ receptors } \\
\hline $\mathrm{A}_{1}$ & $\mathrm{G}_{\mathrm{i}} / \mathrm{o}_{0}$ & $\begin{array}{l}\text { R-PIA, GW493838, CHA, CPA, CCPA, } \\
\text { TCPA, 2'-Me-CCPA, GR79236, } \\
\text { selodenoson, capadenoson, } \\
\text { tecadenoson, GS9667 }\end{array}$ & $\begin{array}{l}\text { PSB36, DPCPX, CPFPX, KW-3902, } \\
\text { toponafylline derenofylline, FK-453, } \\
\text { SLV320, WRC-0571, DU172 }\end{array}$ & PD81723 (positive) \\
\hline $\mathrm{A}_{2 \mathrm{~A}}$ & $\mathrm{G}_{\mathrm{s}}$ & $\begin{array}{l}\text { CGS21680, ATL-313, ATL-146e, } \\
\text { UK-432097, compound 4g, } \\
\text { sonedenoson, binodenoson, } \\
\text { regadenoson }\end{array}$ & $\begin{array}{l}\text { KW6002, CSC, MSX-2, SYN-115, } \\
\text { BIIB014, ST-1535, SCH442416, } \\
\text { ZM241385, SCH58261, preladenant }\end{array}$ & - \\
\hline $\mathrm{A}_{2 \mathrm{~B}}$ & $\mathrm{G}_{\mathrm{s}}, \mathrm{G}_{\mathrm{q}}$ & NECA, Bay 60-6583 & $\begin{array}{l}\text { PSB603, PSB-0788, PSB1115, ATL } \\
\text { 802, LAS8096, MRS1754, CVT- } \\
\text { 6883, MRE -2029-F20 }\end{array}$ & - \\
\hline $\mathrm{A}_{3}$ & $\mathrm{G}_{\mathrm{s}}, \mathrm{G}_{\mathrm{q}}$ & $\begin{array}{l}\text { CF-101, CF-102, CF-502, CO 608,039, } \\
\text { HEMADO, MRS 5151, IB-MECA, } \\
\text { MRS5698 }\end{array}$ & $\begin{array}{l}\text { KF26777, PSB-10, PSB-11, MRE- } \\
\text { 3008-F20, MRS1220,VUF5574, } \\
\text { MRS1523, MRS1191 }\end{array}$ & $\begin{array}{l}\text { LUF6000 (positive), LUF6096 } \\
\quad \text { (positive) }\end{array}$ \\
\hline
\end{tabular}

A317491, 5-[[(3-phenoxyphenyl)methyl][(1S)-1,2,3,4-tetrahydro-1-naphthalenyl]amino]carbonyl]-1,2,4-benzenetricarboxylic acid sodium salt hydrate; A438079, 3-(5-(2,3dichlorophenyl)-1H-tetrazol-1-yl)methyl pyridine hydrochloride hydrate; A740003, $N$-(1-\{[(cyanoimino)(5-quinolinylamino) methyl] amino\}-2,2-dimethylpropyl)-2(3,4-dimethoxyphenyl)acetamide; A804598, $N$-Cyano- $N^{\prime \prime}$-[(1S)-1-phenylethyl]- $N^{\prime}$-5-quinolinyl-guanidine; A839977, 1-(2,3-dichlorophenyl)- $N$-[[2-(2-pyridinyloxy) phenyl]methyl]-1H-tetrazol-5-amine; ADP $\beta$ S, adenosine 5-O-(2-thiodiphosphate); AF-219, 5-(2,4-diaminopyrimidin-5-yl)oxy-2-methoxy-4-propan-2-ylbenzenesulfonamide; AF-906, 2-[[4-amino-5-(5-iodo-4-methoxy-2-propan-2-ylphenoxy)pyrimidin-2-yl] amino]propane-1,3-diol; Ap $p_{5} A$, P1,P5-Di(adenosine-5')pentaphosphate; AR-C67085, [[[[(2R,3S,4R,5R)-5-(6amino-2-propylsulfanylpurin-9-yl)-3,4-dihydroxyoxolan-2-yl]methoxy-hydroxyphosphoryl] oxy-hydroxyphosphoryl]-dichloromethyl]phosphonic acid; AR-C 66096, 2-(propylthio)adenosine5'-O-( $\beta, \gamma$-difluoromethylene)triphosphate tetrasodium salt; ARL66096, 2-(propylthio)adenosine-5'-O-( $\beta, \gamma$-difluoromethylene)triphosphate tetrasodium salt; ATL-146e, 4-\{3-[6-amino-9-(5ethylcarbamoyl-3,4-dihydroxy-tetrahydro-furan-2-yl)-9H-purin-2-yl]-prop-2-ynyl]-cyclohexanecarboxylic acid methyl ester; ATL-313, methyl 4-[3-[6-amino-9-[(2R,3R,4S,5S)-5-(cyclopropylcarbamoyl)-3,4-dihydroxyoxolan-2-yl]purin-2-yl]prop-2-ynyl]piperidine-1-carboxylate; ATP $\gamma \mathrm{S}$, adenosine-5'-( $\gamma$-thio)-triphosphate; AZD1283, ethyl 5-cyano-2-methyl-6[4-[[[(phenylmethyl)sulfonyl]aminolcarbonyl]-1-piperidinyl]-3-pyridinecarboxylate; 5-BDBD, 5-(3-bromophenyl)-1,3-dihydro-2H-benzofuro[3,2-el-1,4-diazepin-2-one; BX-430, $N$-[2,6-dibromo-4-(1-methylethyl)phenyl]- $N^{\prime}$-(3-pyridinyl)urea; BzATP, 2'(3')-O-(4-benzoylbenzoyl)adenosine 5 '-triphosphate triethylammonium; CCPA, 2-chloroN6-cyclopentyladenosine; CF-502, $\left[\left(1^{\prime} R, 2^{\prime} R, 3^{\prime} S, 4^{\prime} R, 5^{\prime} S\right)-4\right.$-\{2-chloro-6-[(3 chlorophenylmethyl)amino] purin-9-yl\}-1-(methylaminocarbonyl)bicyclo[3.1.0]hexane-2,3diol]; CHA, N6-cyclohexyl adenosine; 2-Cl-ADP $(\alpha$-BH3), [[( $2 R, 3 S, 4 R, 5 R)$-5-(6-amino-2-chloropurin-9-yl)-3,4-dihydroxyoxolan-2-yl]methoxy phosphonooxyphosphoryl]boron(1-); CPA, $N^{6}$-cyclopentyladenosine; CPFPX, 8-cyclopentyl-3-(3-fluoranylpropyl)-1-propyl-7H-purine-2,6-dione; CSC, 8-[(E)-2-(3-chlorophenyl)vinyl]-1,3,7-trimethyl-3, 7-dihydro-1Hpurine-2,6-dione; CVT-6883, 3-ethyl-3,9-dihydro-1-propyl-8-[1-[[3-(trifluoromethyl)phenyl]methyl]-1H-pyrazol-4-yl]-1H-purine-2,6-dione; CVT-6883, 3-ethyl-3,9-dihydro-1propyl-8-[1-[[3-(trifluoromethyl)phenyl]methyl]-1H-pyrazol-4-yl]-1H-purine-2,6-dione; DPCPX, 8-cyclopentyl-1,3-dipropylxanthine; GR79236, $N$-[(1S,2S)-2-hydroxycyclopentyl]adenosine; GS9667, 5'-S-(2-fluorophenyl)-N-[(1R,2R)-2-hydroxycyclopentyl]-5'-thioadenosine; GW493838, (2S,3S,4R,5R)-2-(5-tert-butyl-1,3,4-oxadiazol-2-yl)-5-\{6-[(4-chloro-2fluorophenyl)amino]-9H-purin-9-yl]oxolane-3,4-diol; HEMADO, 2-(1-hexynyl)- $N$-methyladenosine; HT-AMP, [(2R,3S,4R,5R)-5-(6-amino-2-hexylsulfanylpurin-9-yl)-3,4-dihydroxyoxolan-2-yl]methyl dihydrogen phosphate; Ip 5 I, diinosine pentaphosphate; KF26777, (2-(4-bromophenyl)-7,8-dihydro-4-propyl-1H-imidazo[2,1-i]purin-5(4H)-one dihydrochloride); KN62, 4-[(2S)-2-[(5-isoquinolinylsulfonyl)methylamino]-3-oxo-3-(4-phenyl-1-piperazinyl)propyl] phenyl isoquinolinesulfonic acid ester; KW-3902, 1,3-dipropyl-8-(3noradamantyl)xanthine, 8-(hexahydro-2,5-methanopentalen-3a(1H)-yl)-3,7-dihydro-1,3-dipropyl-1H-purine-2,6-dione; KW6002, (E)-8-(3,4-dimethoxystyryl)-1,3-diethyl-7-methylxanthine, 8-[(1E)-2-(3,4-dimethoxyphenyl)ethenyl]-1,3-diethyl-3,7-dihydro-7-methyl-1H-purine-2,6-dione; L- $\beta, \gamma$-meATP, L-beta,gamma-metilen ATP; 8MDP, 2,2', $2^{\prime \prime}, 2^{\prime \prime \prime}-[[4,8-$ bis(hexahydro-1 $(2 H)$-azocinyl)pyrimido[5,4- $d$ ] pyrimidine-2,6-diyl]dinitrilo]tetrakisethanol; $\alpha, \beta$-meATP, alpha, beta metilen ATP; 2 '-Me-CCPA, 2 '-metil 2-chloro-N6-cyclopentyladenosine; 2-MeSADP, $[(2 R, 3 S, 4 R, 5 R)$-5-(6-amino-2-methylsulfanylpurin-9-yl)-3,4-dihydroxyoxolan-2-yl]methylphosphono hydrogen phosphate; 2-MeSATP, 2-(methylthio)adenosine 5'triphosphate tetrasodium salt; MRS1191, 3-ethyl-5-benzyl-2-methyl-4-phenylethynyl-6-phenyl-1,4-( \pm )-dihydropyridine-3,5-dicarboxylate; MRS1220, 9-chloro-2-(2-furyl)-5phenylacetylamino[1,2,4]-triazolo[1,5-c]quinazoline; MRS1523, 2,3-diethyl-4,5-dipropyl-6-phenylpyridine-3-thiocarboxylate-5-carboxylate; MRS1754, 8-[4-[[(4cyano)phenylcarbamoylmethyl]oxy] phenyl]-1,3-di-(n-propyl)xanthine; MRS2179, $2^{\prime}$-deoxy- $N^{6}$-methyladenosine $3^{\prime}, 5^{\prime}$-bisphosphate tetrasodium salt; MRS2211, 2-[(2-chloro-5-nitrophenyl)azo]-5-hydroxy-6-methyl-3-[(phosphonooxy)methyl]-4-pyridinecarboxaldehyde disodium salt; MRS2279, (1 $\left.R^{*}, 2 S^{*}\right)-4$-[2-chloro-6-(methylamino)-9H-purin-9-yl]-2-(phosphonooxy)bicyclo[3.1.0]hexane-1-methanol dihydrogen phosphate ester diammonium salt; MRS 2365 , [[(1R,2R,3S,4R,5S)-4-[6amino-2-(methylthio)-9H-purin-9-yl]-2,3dihydroxybicyclohex-1-yl]methyl] diphosphoric acid mono ester; MRS2567, 1-isothiocyanato-4-[2-(4-isothiocyanatophenyl)ethyl]benzene; MRS2578, 1,4-di[3-(3-isothiocyanatophenyl)thioureido]butane; MRS2603, [(2Z)-2-[(4-chloro-3-nitrophenyl)hydrazinylidene]-4-formyl-6-methyl-5-oxopyridin-3-yl]methyl dihydrogen phosphate; MRS2693, 5-iodouridine-5'-O-diphosphate trisodium salt; MRS2905, 2-thiouridine-5'-O- $\alpha$, $\beta$-methylene)diphosphate trisodium salt; MRS2957, $\mathrm{P}^{1}$-[5' $N^{4}$ methoxycytidyl)]- $\mathrm{P}^{3}$-(5'-uridyl)-triphosphate tri(triethylammonium) salt; MRS4062, [[(2R,3S,4R,5R)-3,4-dihydroxy-5-[2-oxo-4-(3-phenylpropoxyamino)pyrimidin-1-yl]oxolan-2yl]methoxy-hydroxyphosphoryl] phosphono hydrogen phosphate; MRS 5151,6-(2-chloro-6-(((9-((1S,2R,3S,4R,5S)-3,4-dihydroxy 5(methylcarbamoyl)bicyclo[3.1.0]hexan-2-yl)-9Hpurin-6-yl)amino)methyl)phenyl)hex-5-ynoic acid; MRS5698, (1S,2R,3S,4R,5S)-4-[6-[(3-chlorophenyl)methyl]amino]-2-[2-(3,4-difluorophenyl)ethynyl]-9H-purin-9-yl]-2,3-dihydroxy- $N$-methylbicyclo[3.1.0] hexane-1carboxamide; NF023, 8,8'-[carbonylbis(imino-3,1-phenylenecarbonylimino)]bis-1,3,5-naphthalene-trisulphonic acid, hexasodium salt; NF157, 8,8'-[carbonylbis[imino-3,1-phenylenecarbonylimino(4-fluoro-3,1-phenylene)carbonyliminol]bis-1,3,5-naphthalenetrisulfonic acid hexasodium salt; NF 279, 8,8'-[carbonylbis(imino-4,1-phenylenecarbonylimino-4,1-phenylenecarbonylimino)]bis-1,3,5-naphthalenetrisulfonic acid hexasodium salt; NF340, 4,4'-(carbonylbis(imino-3,1-(4-methylphenylene)carbonylimino)) bis(naphthalene-2,6-disulfonic acid) tetrasodium salt; NF449, 4,4',4",4"'-[carbonylbis(imino-5,1,3-benzenetriyl-bis(carbonylimino))]tetrakis1,3-benzenedisulfonic acid, octasodium salt; NF546, 4,4'-(carbonylbis(imino-3,1-phenylene-carbonylimino-3,1-(4-methyl-phenylene)carbonylimino))-bis(1,3-xylene-alpha,alpha';-diphosphonic acid tetrasodium salt; NF770, 5-methoxy-3-[[3-[[3-[[3-[[5-[(8-methoxy-3,6-disulfonaphthalen-2-yl)carbamoyl]-2 methylphenyl]carbamoyl]phenyl]carbamoylamino]benzoyl]amino]-4 methylbenzoyl]amino]naphthalene-2,7-disulfonic acid; NF778, 6,6-(carbonylbis(imino-3,1-phenylenecarbonylimino-3,1(4-methyl-phenylene)carbonylimino))bis(1-methoxy-naphthalene-3,5-disulfonic acid) tetrasodium salt; (N)methanocarba UTP, I[4-(2,4-dioxopyrimidin-1-yl)-2,3-dihydroxy-1bicyclo[3.1.0]hexanyl]methoxy-hydroxyphosphoryl] phosphono hydrogen phosphate; PAPET-ATP, 2-[2-(4-aminophenyl)ethylthio]adenosine 5'-triphosphate; 3-phenacyl UDP, $[(2 R, 3 S, 4 R, 5 R)-5$-(2,4-dioxo-3-phenacylpyrimidin-1-yl)-3,4-dihydroxyoxolan-2-yl]methyl phosphono hydrogen phosphate; PPADS, pyridoxalphosphate-6-azophenyl-2',4'disulfonic acid; PPNDS, pyridoxal-5'-phosphate-6-(2'-naphthylazo-6'-nitro-4' $8^{\prime}$-disulfonate); PSB0474, 3-(2-oxo-2-phenylethyl)-uridine-5'-diphosphate disodium salt; PSB-0739, 1-amino-9,10-dihydro-9,10-dioxo-4-[[4-(phenylamino)-3-sulfophenyl]amino]-2-anthracenesulfonic acid sodium salt; PSB-0788, 8-[4-[4-(4-chlorobenzyl)piperazide-1sulfonyl)phenyl]]-1-propylxanthine; PSB-10, 8-ethyl-1,4,7,8-tetrahydro-4-methyl-2-(2,3,5-trichlorophenyl)-5H-imidazo[2,1-i]purin-5-one monohydrochloride; PSB-10211, 1-amino-4[3-[(4,6-dichloro-1,3,5-triazin-2-yl)amino]anilino]-9,10-dioxoanthracene-2-sulfonic acid; PSB-11, $(8 R)$-8-ethyl-1,4,7,8-tetrahydro-4-5H-imidazo[2,1-i]purin-5-one hydrochloride; PSB1115, 4-(2,3,6,7-tetrahydro-2,6-dioxo-1-propyl-1H-purin-8-yl)-benzenesulfonic acid; PSB-12062, 10-[(4-methylphenyl)sulfonyl]-10H-phenoxazine; PSB12379, $N^{6}$-benzyl- $\alpha, \beta$-methyleneadenosine 5'-diphosphate disodium salt; PSB36, 1-butyl-3-(3-hydroxypropyl)-8-(3-noradamantyl)xanthine,1-butyl-8-(hexahydro-2,5 methanopentalen-3a(1H)-yl)-3,9-dihydro-3-(3-hydroxypropyl)-1H-purine-2,6-dione; PSB603, 8-[4-[4-(4-chlorophenzyl)piperazide-1-sulfonyl)phenyl]]-1-propylxanthine; Ro $0437626, \quad N$-[(1R)-2-[[(1S,2R,3S)-1-(cyclohexylmethyl)-3-cyclopropyl-2,3-dihydroxypropyl]amino]-2-oxo-1-(4 thiazolylmethyl)ethyl]-1H-benzimidazole-2-carboxamide; R-PIA, $(2 R, 3 S, 4 R, 5 R)$-2-(hydroxymethyl)-5-[6-[[(2R)-1-phenylpropan-2-yl]amino]purin-9-yl]oxolane-3,4-diol; SCH442416, 2-(2-furanyl)-7-[3-(4-methoxyphenyl)propyl]-7H-pyrazolo [4,3-e][1,2,4]triazolo[1,5-c]pyrimidin-5-amine; SCH58261, 7-(2-phenylethyl)-5-amino-2-(2-furyl)-pyrazolo-[4,3-e]-1,2,4-triazolo[1,5-c]pyrimidine; SLV320, trans-4-[(2-phenyl-7H-pyrrolo[2,3-d] pyrimidin-4-yl)amino]cyclohexanol; ST-1535, 2-butyl-9-methyl-8-(2H-1,2,3-triazol-2-yl)-9H-purin-6-amine; SYN-115, 4-hydroxy$N$-[4-methoxy-7-(4-morpholinyl)-2-benzothiazolyl]-4-methyl-1-piperidinecarboxamide; TCPA, $N^{6}$-cyclopentyl-2-(3-phenylaminocarbonyltriazene-1-yl)adenosine; 2-thioUDP, $[(2 R, 3 S, 4 R, 5 R)$-3,4-dihydroxy-5-(4-oxo-2-sulfanylidenepyrimidin-1-yl)oxolan-2-yl]methyl phosphono hydrogen phosphate; 2-thioUTP, 2-thiouridine-5'-triphosphate; TNPATP, $2^{\prime}, 3^{\prime}-O$ - $(2,4,6$-trinitrophenyl) adenosine 5'-triphosphate; UK-432097, $(2 S, 3 S, 4 R, 5 R)$-5-\{6-[(2,2-diphenylethyl)amino]-2-[(2-\{ $N$-[1-(pyridin-2-yl)piperidin-4-yl]-(Chydroxycarbonimidoyl)amino\}ethyl)carbamoyl]-9H-purin-9-yl\}- $N$-ethyl-3,4-dihydroxyoxolane-2-carboximidic acid; VUF5574, $N$-(2-methoxyphenyl)-N $N^{\prime}$-[2-(3-pyridinyl)-4quinazolinyl]-urea; WRC-0571, 5-[[9-methyl-8-[methyl(propan-2-yl)amino]purin-6-yl] amino]bicyclo[2.2.1] heptan-2-ol; ZM241385, 4-[2-(7-amino-2-(2-furyl)[1,2,4-triazolo[2,3a] $[1,3,5]$ triazin-5-yl-amino] ethyl phenol.

Preclinical studies support the use of agents targeting the purinergic system for treating immune and/or inflammatory disorders (see Table 4). In the wake of these preclinical findings, several ligands acting on various purinergic targets have been or are being tested in clinical trials (see Table 5). 
TABLE 2

Commercially available blockers for purinergic enzymes and transporters

\begin{tabular}{|c|c|}
\hline Molecular Target & Inhibitors \\
\hline CD39 & $\begin{array}{l}\text { Sodium polyoxotungstate (POM-1), 1-amino-4-(4-chlorophenyl)aminoanthraquinone-2- } \\
\text { sulfonic acid sodium salt (PSB-069) }\end{array}$ \\
\hline CD73 & $\begin{array}{l}\text { Adenosine } 5^{\prime}-\left(\alpha, \beta \text {-methylene)diphosphate, } N^{6} \text {-benzyl- } \alpha, \beta \text {-methyleneadenosine } 5^{\prime}-\right. \\
\text { diphosphate disodium salt (PSB-12379), } 1 \text {-amino-4-(anthracen-2-ylamino)-9,10- } \\
\text { dioxoanthracene-2-sulfonate (PSB-0963), } N^{6} \text {-phenylethyl- adenosine-5'-O- } \\
\text { [(phosphonomethyl)phosphonic acid] (PSB-12425),(( } S)-((2 R, 3 S, 4 R, 5 R)-5 \text { - }(6 \text {-(benzyloxy)- } \\
\text { 9H-purin-9-yl)-3,4-dihydroxytetrahydrofuran-2-yl)methoxy)(hydroxy)phosphoryl) } \\
\text { methyl)phosphonic acid (PSB-12431), }((S)-(((2 R, 3 S, 4 R, 5 R)-5 \text {-(6-(benzylthio)-9H-purin-9- } \\
\text { yl)-3,4-dihydroxytetrahydrofuran-2-yl)methoxy)(hydroxy)phosphoryl)methyl)phosphonic } \\
\text { acid (PSB-12553), quercetin }\end{array}$ \\
\hline CD38 & $\begin{array}{l}\text { Carba- } \beta \text {-NAD, pseudocarba- } \beta \text {-NAD, luteolin, luteolinidin, kuromanin, 4,4'-dihydroxy- } \\
\text { azobenzene (DHAB), ara-F-NAD, ara-NAD, deoxy NR, deoxy-MNR, ara-F-NMN }\end{array}$ \\
\hline Nucleoside transporters & $\begin{array}{l}\left.2,2^{\prime}, 2^{\prime \prime}, 2^{\prime \prime \prime} \text {-[[4,8-bis(hexahydro-1 }(2 H) \text {-azocinyl)pyrimido[5,4- } d\right] \text { pyrimidine-2,6- } \\
\text { diyl]dinitrilo]tetrakisethanol (8MDP), cilostazol, dilazep, dipyridamole, 5-iodotubercidin, } \\
\text { 6-S-[(4-nitrophenyl)methyl]-6-thioinosine (NBMPR), TC-T6000 }\end{array}$ \\
\hline Adenosine deaminase & $\begin{array}{l}\text { erythro-9-(2-Hydroxy-3-nonyl)adenine hydrochloride (EHNA), pentostatin, } \\
\text { 1-deazaadenosine, cladribine }\end{array}$ \\
\hline
\end{tabular}

$\beta$-NAD, $\beta$-nicotinamide adenine di nucleotide; NBMPR, 6-S-[(4-nitrophenyl)methyl]-6-thioinosine; PSB-069, 1-amino-4-(4-chlorophenyl)aminoanthraquinone-2-sulfonic acid sodium salt; PSB-12431, (( $S)-(((2 R, 3 S, 4 R, 5 R)-5$-(6-(benzyloxy)-9H-purin-9-yl)-3,4-dihydroxytetrahydrofuran-2 yl)methoxy)(hydroxy)phosphoryl)methyl)phosphonic acid; PSB-12553, (( $S$ )-(( $(2 R, 3 S, 4 R, 5 R)-5$-(6-(benzylthio)-9H-purin-9-yl)-3,4-dihydroxytetrahydrofuran2-yl)methoxy)(hydroxy)phosphoryl)methyl)phosphonic acid; TC-T6000, 2,2'-[[4,8-bis[bis(2-methylpropyl)amino]pyrimido[5,4-d]pyrimidine2,6-diyl]diimino]bis-ethanol.

\section{Purinergic Signaling in Immune Cells Contributes to Homeostasis}

Emerging evidence indicates that purines contribute to immune homeostasis (Hasko and Cronstein, 2004; Trautmann, 2009; Junger, 2011; Csóka et al., 2012b, 2015a; Longhi et al., 2013; Burnstock and Boeynaems, 2014; Sevigny et al., 2015; Cekic and Linden, 2016; Hasko et al., 2018). Under resting or physiologic conditions, immune cells release low levels of ATP, creating a "purinergic halo" in their immediate environment (Trautmann, 2009). Such an ATP "halo" is a low-intensity signal addressed to the closest neighboring cells, which makes these neighboring "target" cells aware of the ATP-emitting cells (Trautmann, 2009). Responses to low ATP concentrations are mediated by high affinity receptors such as $\mathrm{P}_{2}, \mathrm{X}_{1} 2 \mathrm{X}_{3}, \mathrm{P}_{2} \mathrm{Y}_{2}$, and
$\mathrm{P}_{2} \mathrm{Y}_{13}\left(\mathrm{EC}_{50}<1 \mu \mathrm{M}\right)$ or by intermediate affinity receptors comprising $\mathrm{P}_{2} \mathrm{X}_{2}, \mathrm{P}_{2} \mathrm{X}_{4}, \mathrm{P}_{2} \mathrm{X}_{5}, \mathrm{P}_{2} \mathrm{X}_{6}, \mathrm{P}_{2} \mathrm{Y}_{1}, \mathrm{P}_{2} \mathrm{Y}_{4}$, and $\mathrm{P}^{2} \mathrm{Y}_{11}\left(\mathrm{EC}_{50}\right.$ 1-20 $\left.\mu \mathrm{M}\right)$ (Trautmann, 2009) (Table 6).

$\mathrm{P} 2$ receptors are involved in regulating homeostasis, as revealed by the alterations of cell and tissue functions in "unstressed" P2-deficient mice. For example, both $\mathrm{P}_{2} \mathrm{Y}_{1}$ or $\mathrm{P} 2 \mathrm{Y}_{12} \mathrm{KO}$ mice exhibit a defect in platelet aggregation and show increased resistance to thromboembolism (Foster et al., 2001; Léon et al., 1999). $\mathrm{P}_{2} \mathrm{Y}_{2} \mathrm{KO}$ mice are characterized by a decrease in vascular cell adhesion molecule 1 expression on endothelial cells (Qian et al., 2016).

The degradation of the physiologically released ATP creates an "adenosine halo," which is also important for maintaining immune homeostasis. For example, $A_{2 \mathrm{~A}}$ receptors are important for $\mathrm{T}$ cell development and

TABLE 3

miRNA involved in the modulation of the purinergic network

\begin{tabular}{llll}
\hline \multirow{2}{*}{ Regulatory miRNA } & $\begin{array}{c}\text { Target in the } \\
\text { Purinergic Pathway }\end{array}$ & Biologic Effect & \multicolumn{1}{c}{ References } \\
\hline P2X7 & miR-150 & Inhibition & Huang et al. (2013) \\
& miR-186 & Inhibition & Zhou et al. (2008) \\
& miR-216b & Inhibition & Zheng et al. (2014) \\
& miR-22 & Inhibition & Jimenez-Mateos et al. (2015) \\
& miR-21 & Inhibition & Boldrini et al. (2015) \\
& miR-125b & Stimulation & Parisi et al. (2016) \\
CD39 & miR-155 & Stimulation & Liu et al. (2015) \\
CD73 & miR-30 family & Inhibition & Bonnin et al. (2016) \\
& miR-340 & Inhibition & Xie et al. (2017) \\
& miR-187 & Inhibition & Wang et al. (2018b) \\
& miR-193b & Inhibition & Zhang et al. (2016) \\
& miR-34b & Inhibition & Ikeda et al. (2012) \\
$\mathrm{A}_{2 \mathrm{~A}}$ & miR-214 & Inhibition & Villar-Menendez et al. (2014) \\
& miR-15 & Inhibition & Zhao et al. (2015) \\
& miR-16 & Inhibition & Heyn et al. (2012) \\
& miR-27b & Inhibition & Heyn et al. (2012) \\
$\mathrm{A}_{2 \mathrm{~B}}$ & miR-128a & Inhibition & Kolachala et al. (2010) \\
& miR-128b & Inhibition & Kolachala et al. (2010) \\
$\mathrm{ADA} 2$ & miR-14b-3p & Inhibition & Kolachala et al. (2010) \\
\hline
\end{tabular}




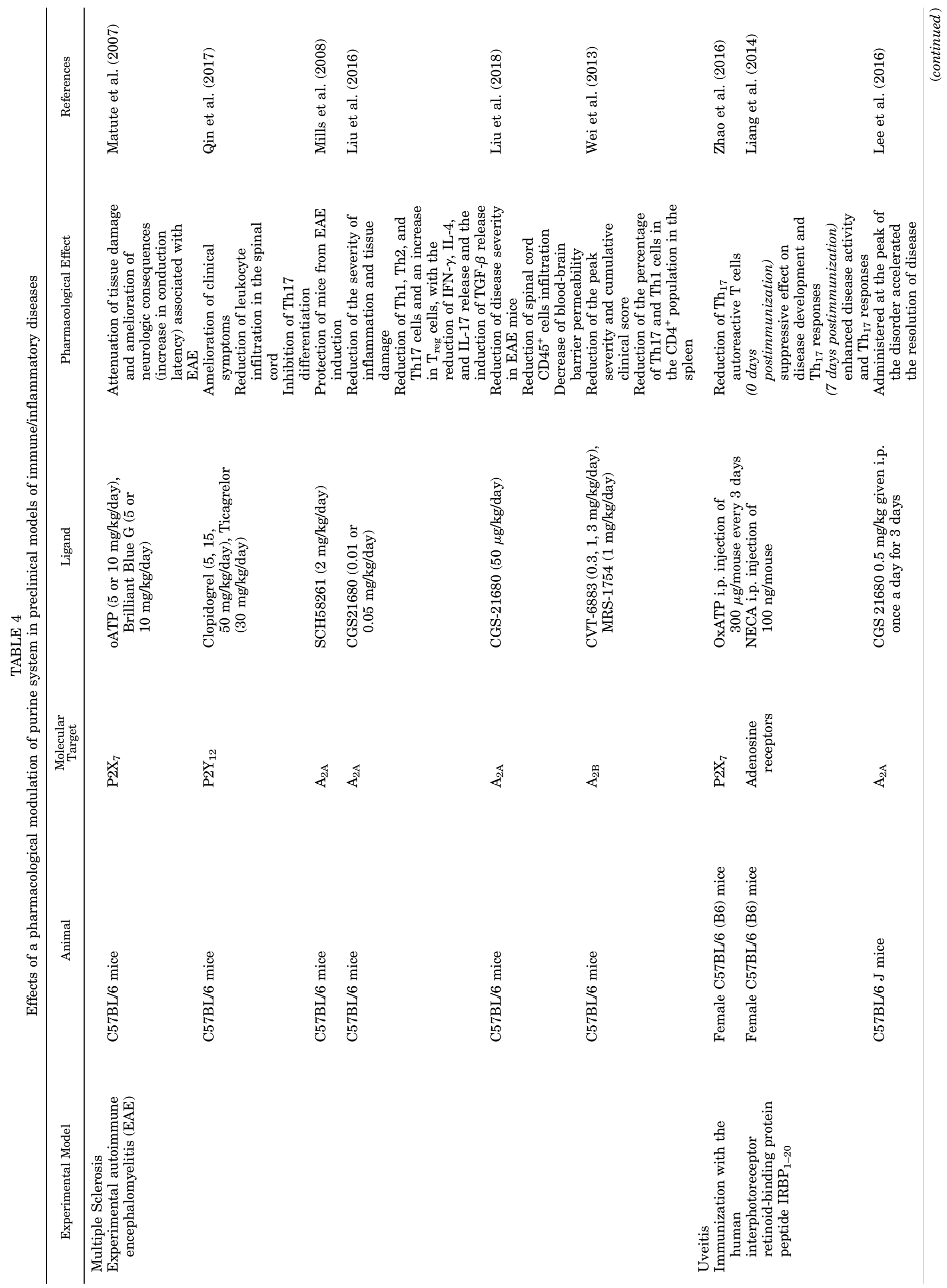




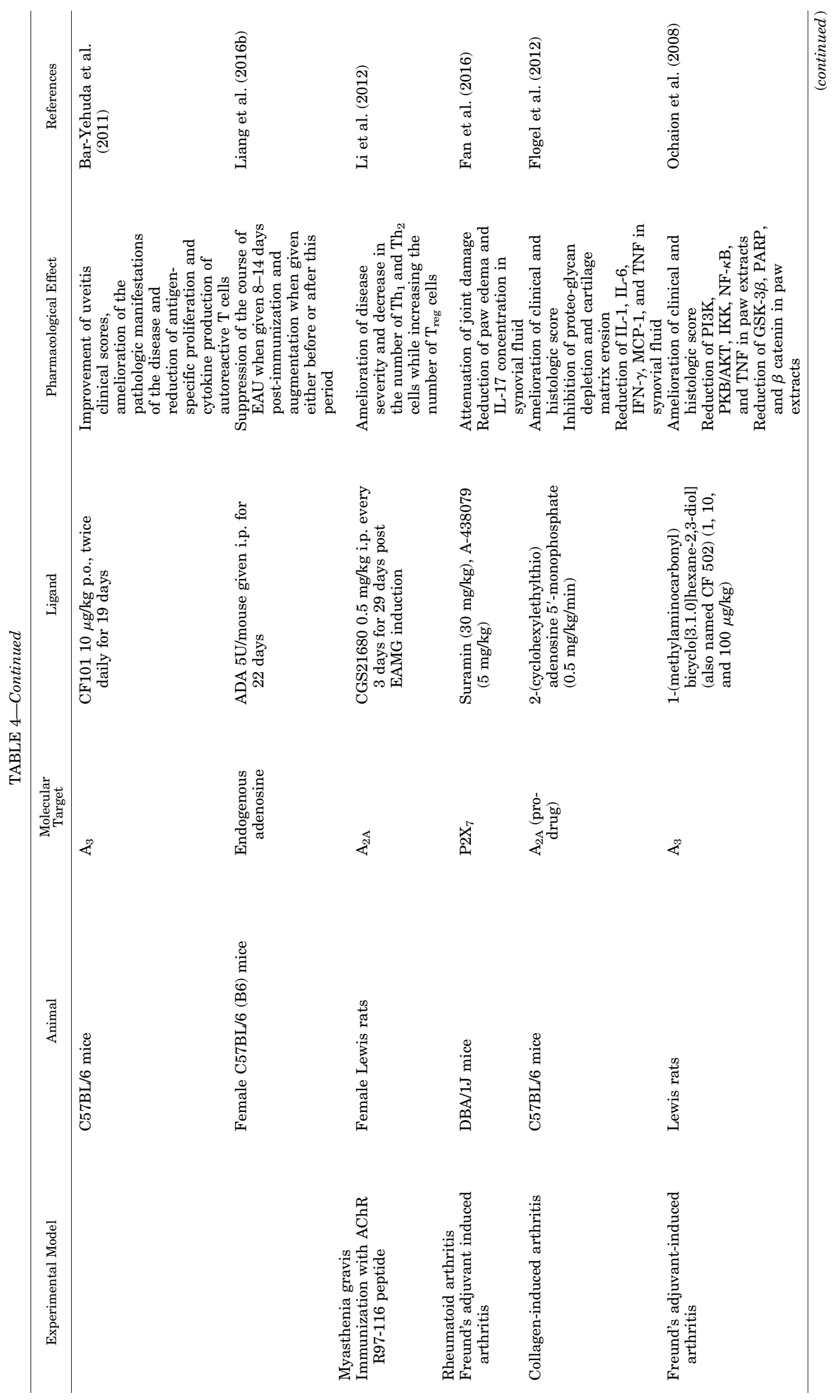




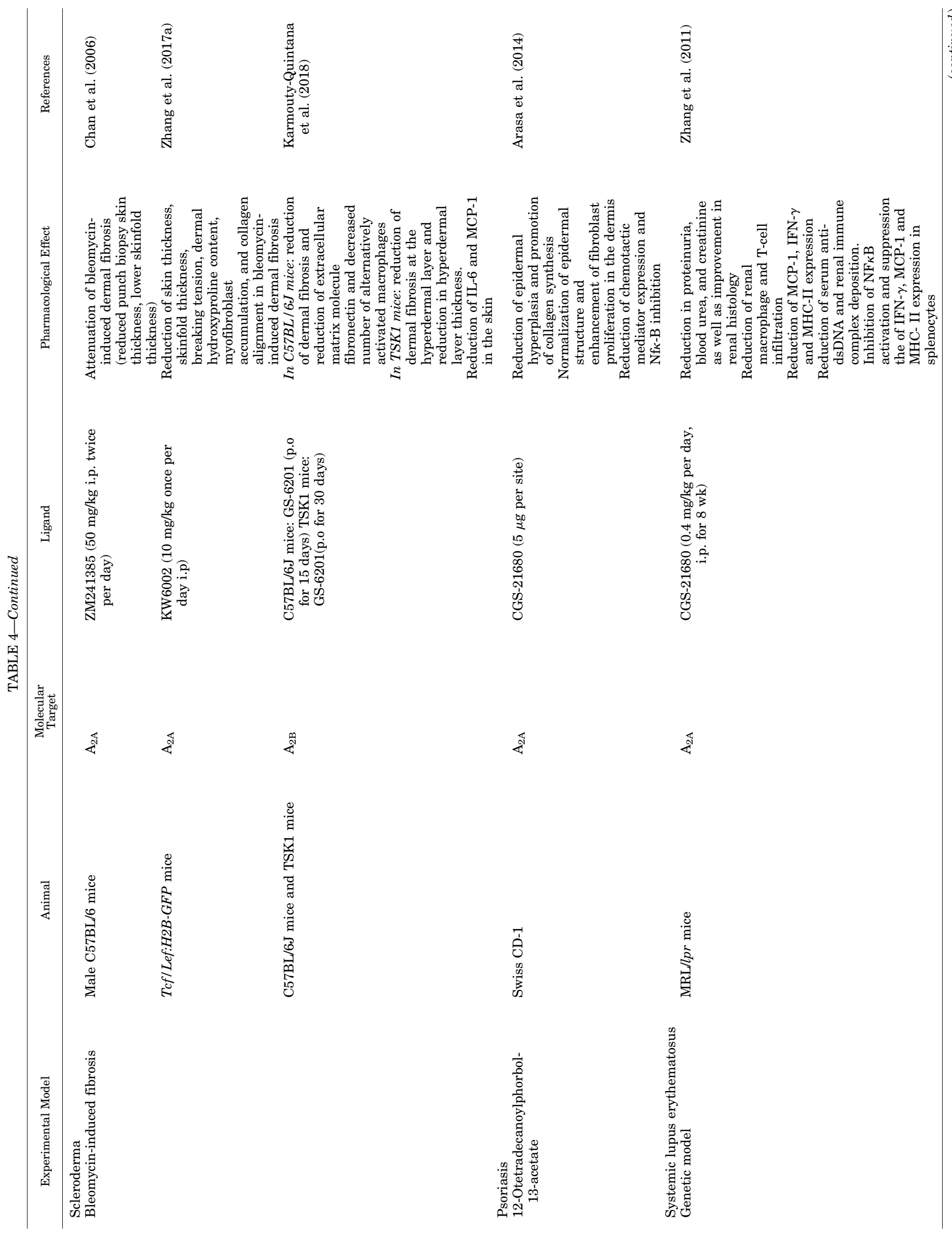




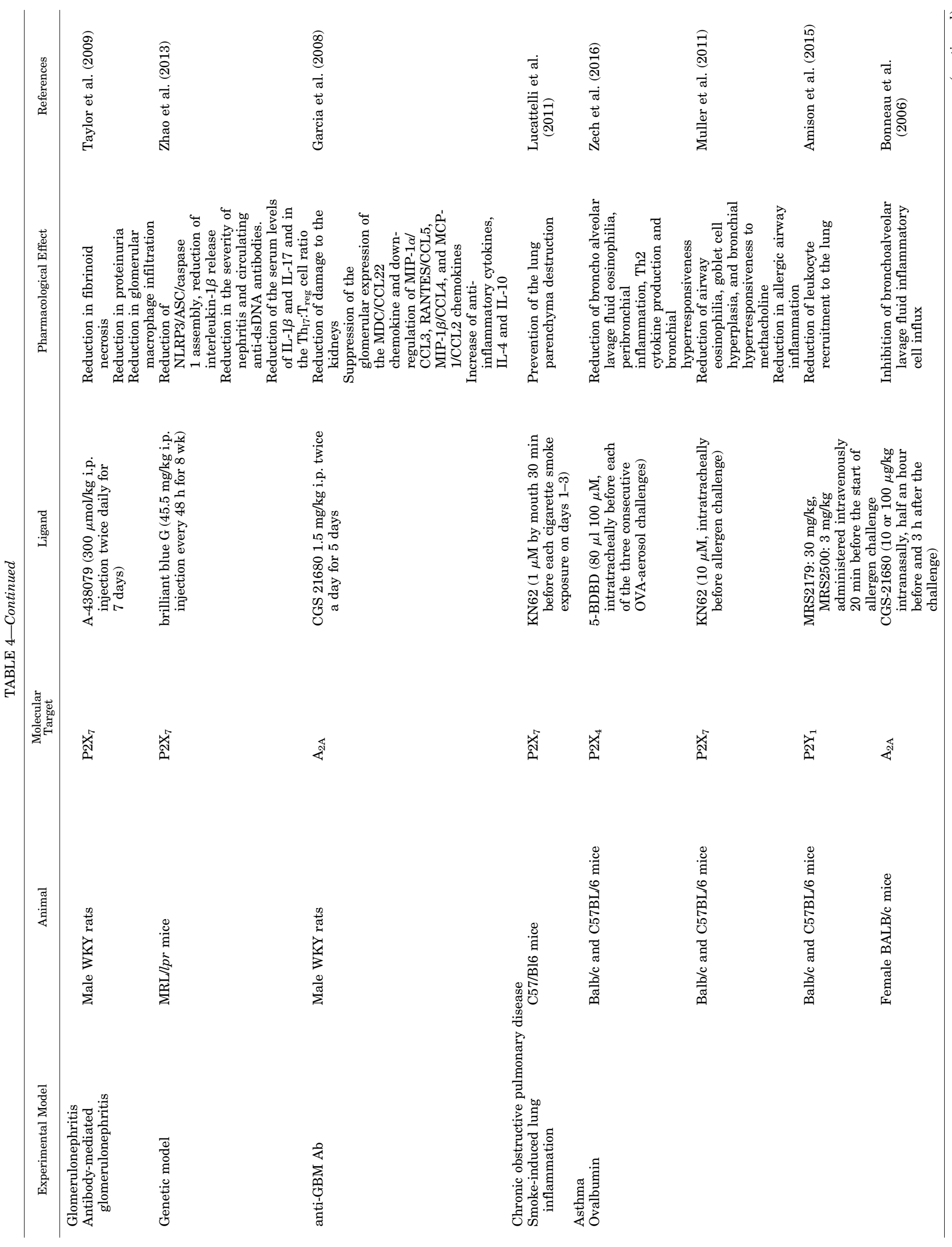




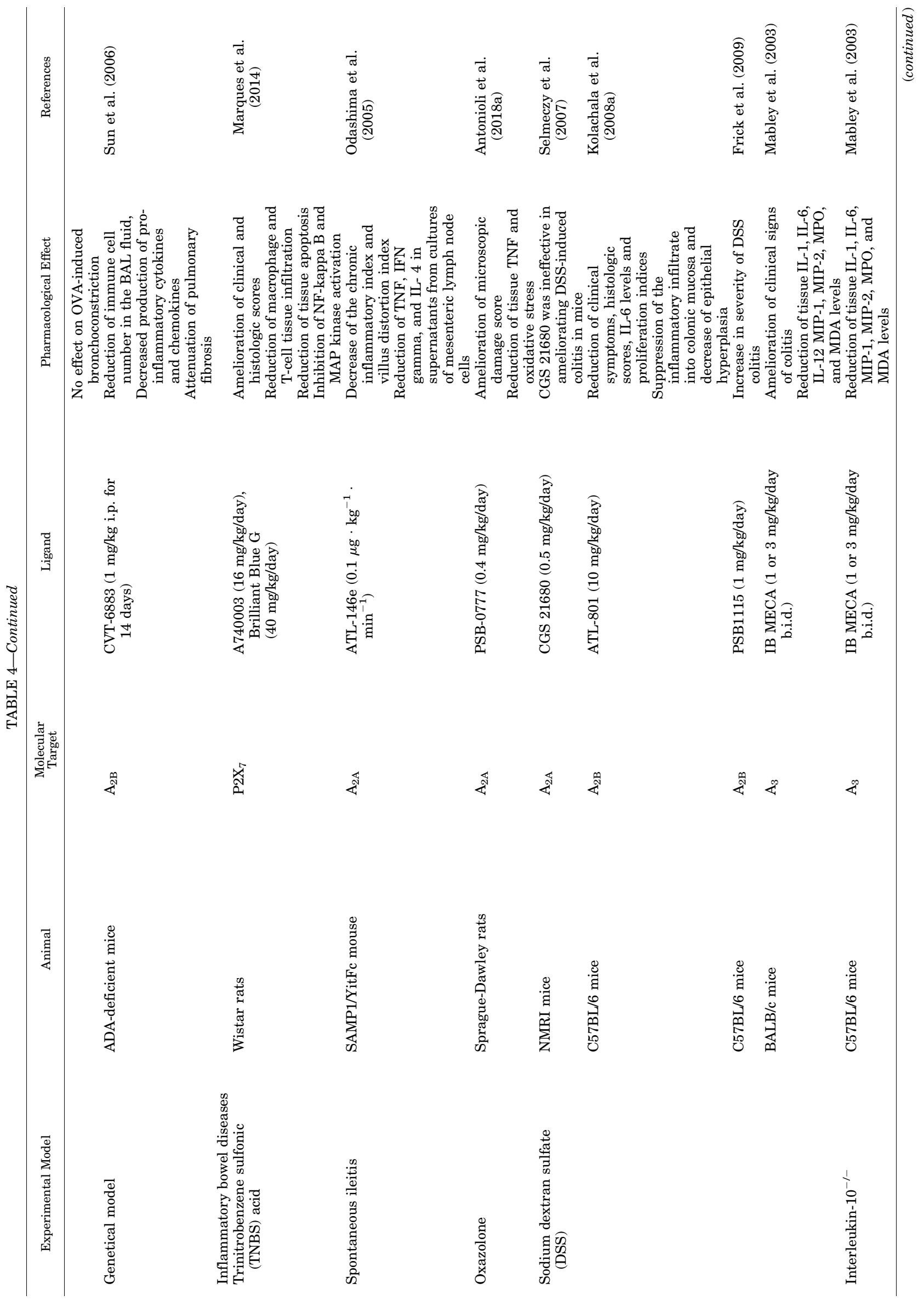




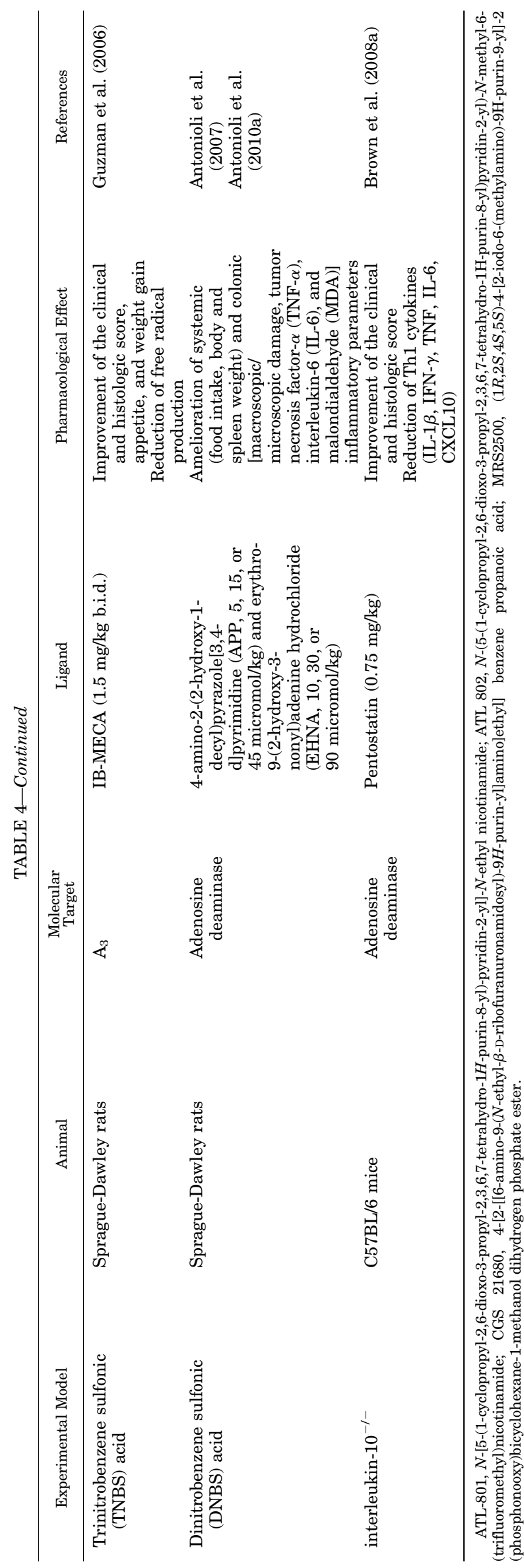

maintenance and to sustain normal numbers of naive $\mathrm{T}$ cells in the periphery (Cekic et al., 2013). $\mathrm{A}_{2 \mathrm{~A}}$ receptors are also important for dampening chondrocyte proinflammatory responses and therefore maintaining a healthy cartilage (Corciulo et al., 2017). $\mathrm{A}_{2 \mathrm{~B}} \mathrm{KO}$ mice show increased basal cytokines and adhesion molecules even in an unchallenged state (Yang et al., 2006). $\mathrm{A}_{2 \mathrm{~B}}$ KO mice develop impaired glucose and lipid metabolism, and their adipose tissue macrophages show decreased alternative activation and increased classical activation with enhanced inflammatory cytokine expression (Csóka et al., 2014).

The duration, magnitude, and composition of the "purinergic halo" surrounding immune cells is tightly calibrated via synthetic and catabolic enzymes, as described above (Antonioli et al., 2012, 2013c; Horenstein et al., 2013) (Table 1). Alterations in the activity of these enzymes can cause immune-mediated disease. CD39 deletion in mice results in impaired glucose tolerance and insulin sensitivity, which is associated with increased systemic levels of proinflammatory cytokines and NF- $\kappa \mathrm{B}$ activation in the liver (Enjyoji et al., 2008). These mice also have decreased NKT cell numbers (Beldi et al., 2008). CD73-deficient mice have constitutively increased monocyte adhesion to endothelium in carotid arteries (Koszalka et al., 2004) and increased endothelial cell adhesion factor expression (Zernecke et al., 2006).

The immune system of adenosine deaminase (ADA)deficient mice is defective both in terms of composition and activity (Whitmore and Gaspar, 2016). These animals have smaller thymi and lymph nodes and fewer cells in lymphoid organs compared with littermate controls (Apasov et al., 2001). They also have severe lymphopenia (affecting T cells, B cells, and NK cells) and impaired cellular and humoral immunity (Whitmore and Gaspar, 2016). Some of these alterations are the result of increased extracellular adenosine accumulation and $\mathrm{P} 1$ receptor stimulation, while others are due to intracellular accumulation of deoxyadenosine (Gessi et al., 2007).

CD38 KO mice display a reduced number of peripheral $\mathrm{T}_{\text {regs }}$ and invariant NKT cells, due to a $\mathrm{NAD}^{+}$-induced cell death process (Chen et al., 2006a,b). In addition, CD38 deficiency in NOD mice accelerates the development of type I diabetes (Chen et al., 2006a).

The number and the activity of basophils and mast cells is markedly enhanced in CD203c-deficient mice, making them more susceptible to chronic allergic pathologies (Tsai et al., 2015). In addition, CD203c knockout mice show a reduction of plasmacytoid dendritic cell (DC) numbers in Peyer's patches in the lamina propria of the small intestine (Furuta et al., 2017).

It is important to stress that with the exception of ADA deficiency, where the immune phenotype of humans is similar to that one observed in mice, the role of purinergic signaling in maintaining immune homeostasis in humans is unknown. 
TABLE 5

Purinergic receptor ligands in clinical studies for treating inflammatory diseases

\begin{tabular}{|c|c|c|c|c|c|c|}
\hline Drug & Target & $\begin{array}{l}\text { Agonist or } \\
\text { Antagonist }\end{array}$ & Disease & Status & Company & References \\
\hline CE-224,535 & P2X7 & Antagonist & Rheumatoid arthritis & Phase 2 & Pfizer & NCT00628095 \\
\hline GSK1482160 & $\mathrm{P} 2 \mathrm{X} 7$ & Antagonist & Inflammatory pain (arthritis) & Phase 1 & Glaxo SmithKline & NCT00849134 \\
\hline PBF-680 & $\mathrm{A}_{1}$ & Antagonist & Asthma & Phase 1 & Palabiofarma & NCT01845181 \\
\hline PBF-680 & $\mathrm{A}_{1}$ & Antagonist & Asthma & Phase 2 & Palabiofarma & NCT02635945 \\
\hline UK 432097 & $\mathrm{~A}_{2 \mathrm{~A}}$ & Agonist & COPD & Phase 2 & Pfizer & NCT00430300 \\
\hline Poclidenoson & $\mathrm{A}_{3}$ & Agonist & Rheumatoid arthritis & Phase 3 & CanFite Pharma & NCT02647762 \\
\hline Poclidenoson & $\mathrm{A}_{3}$ & Agonist & Psoriasis & Phase 3 & CanFite Pharma & NCT00428974 \\
\hline PBF-677 & $\mathrm{A}_{3}$ & Agonist & Ulcerative colitis & Phase 2 & Palabiofarma & NCT02639975 \\
\hline
\end{tabular}

\section{The Concept of Immune-Mediated Inflammatory Diseases}

Inflammation is a complex response of the immune system to harmful stimuli affecting the organism, which stimuli include infection, toxic compounds, irradiation, and tissue injury. Inflammation is essential for stemming injurious stimuli and initiating the healing process (Medzhitov, 2008). During the acute phase of inflammation, fluid, inflammatory cells, and proinflammatory mediators accumulate in the extravascular space at the site of injury or invasion. The proinflammatory mediators include interleukins, colony stimulating factors, interferons (IFNs), TNFs, and chemokines, as well as histamine, kinins, coagulation factors, complement factors, nitric oxide, and proinflammatory eicosanoids, such as prostaglandins and leukotrienes (Turner et al., 2014; Chen et al., 2017). In addition to proinflammatory cells and mediators, a wide variety of anti-inflammatory molecular mechanisms and cellular interactions are in place to minimize the extent of tissue injury at the site of the harmful stimulus and surrounding healthy tissue, thus contributing to the eventual restoration of tissue homeostasis (Medzhitov, 2008). The most notable antiinflammatory mediators are IL-10, TGFs, carbon monoxide, and glucocorticoids. Finally, there are several mechanisms that operate to terminate the inflammatory process and initiate tissue restitution, the mechanisms of which are collectively called inflammatory resolution. Inflammatory resolution is mediated by anti-inflammatory eicosanoids, such as lipoxins, as well as resolvins, protectins, and maresins (Serhan and Levy, 2018).

Deficient regulation of anti-inflammatory processes and resolution of inflammation can lead to overactivation and chronicization of the phlogistic process, which represent a "common soil" of ostensibly unrelated conditions that share common immunologic pathways, collectively named IMIDs (Scrivo et al., 2011). IMID is thus an umbrella term encompassing a set of various diseases, such as multiple sclerosis (MS), rheumatoid arthritis (RA), uveitis, myasthenia gravis, psoriasis, scleroderma, systemic lupus erythematosus (SLE), glomerulonephritis, chronic obstructive pulmonary disease (COPD), asthma, and inflammatory bowel diseases (IBDs), which are characterized by increased and prolonged inflammation in target organs and frequently by a plethora of systemic effects as well (David et al., 2018).

In addition to the "classical" pro- and anti-inflammatory mediators described above, purines are emerging as powerful extracellular signaling molecules, which orchestrate the onset, magnitude duration, and resolution of the inflammatory response through the activation of purinergic receptors, which are widely expressed on most cell types involved in inflammatory processes (Hasko et al., 1996, 1998, 2000a,b, 2008, 2011; Nemeth et al., 2005, 2006, 2007; Csóka et al., 2008, 2010, 2012, 2015a,b, 2018; Ramanathan et al., 2009; Himer et al., 2010; Hasko and Pacher, 2012; Koscso et al., 2013; Burnstock and Boeynaems, 2014; Antonioli et al., 2018). Alterations in the purinergic machinery are a common contributory factor to the pathophysiological processes underlying the onset and development of IMIDs.

\section{A. Multiple Sclerosis}

MS is a complex, chronic, progressive immune-mediated demyelinating disease causing focal damage to the white matter attacking different regions of the central nervous system. The disease has a relapsing-remitting course and a range of clinical symptoms (e.g., autonomic, visual, motor, and sensory problems), depending on where the demyelination and axonal loss have occurred (Trapp and Nave, 2008). The inflammatory process is characterized by marked infiltration of monocytes, DCs, T and B cells, as well as by activation of resident microglia and macrophages, induction of oxidative stress pathways, and alterations of the blood-brain barrier permeability (Dargahi et al., 2017). Of note, experimental autoimmune encephalomyelitis (EAE) in rodents is the most commonly used model for MS, mimicking several of the key pathophysiological features of the human disease, such as demyelination, axonal loss, inflammation, and gliosis (Constantinescu et al., 2011).

Brain sections from MS patients were immunopositive for $\mathrm{P}_{2} \mathrm{X}_{1}, \mathrm{P}_{2} \mathrm{X}_{2}, \mathrm{P} 2 \mathrm{X}_{3}, \mathrm{P}_{2} \mathrm{X}_{4}$, and $\mathrm{P} 2 \mathrm{X}_{7}$ receptors (Amadio et al., 2010). By contrast, the $\mathrm{P} \mathrm{X}_{6}$ receptor was undetectable (Amadio et al., 2010). $\mathrm{P}_{6} \mathrm{X}_{7}$ receptor expression is increased on astrocytes in active brain lesions (Narcisse et al., 2005; Amadio et al., 2017) and on microglia of the optic nerve (Matute et al., 2007) of MS patients. $\mathrm{P} 2 \mathrm{X}_{7}$ receptor expression is increased 


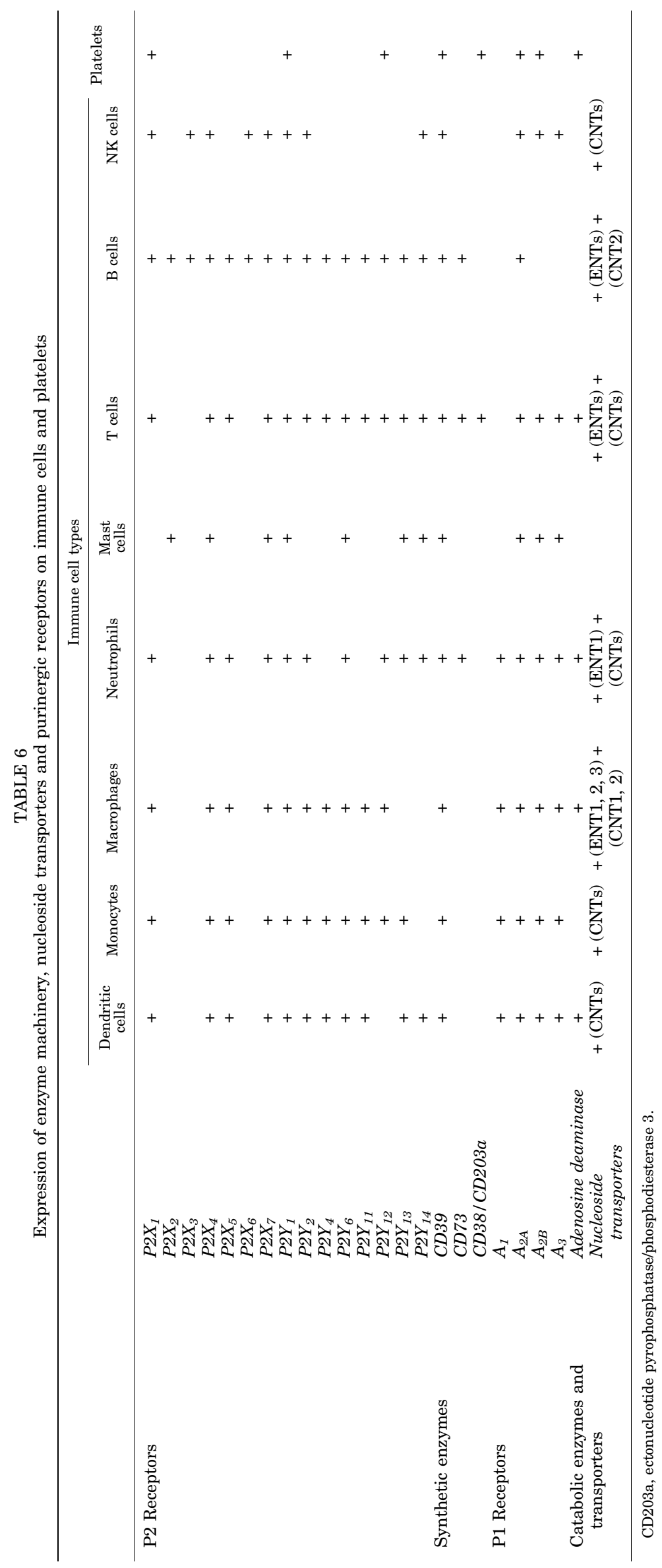


on oligodendrocytes also in normal-appearing axon tracts in patients with MS; this may indicate an early role for $\mathrm{P}_{2} \mathrm{X}_{7}$ receptors in disease progression (Matute et al., 2007). In addition to the brain, increased $P 2 X_{7}$ receptor immunoreactivity was also observed in microglia/ macrophages in the spinal cord of MS patients (Yiangou et al., 2006).

The analysis of blood monocytes obtained from MS patients did not reveal any differences in $\mathrm{P}_{2} \mathrm{X}_{7}$ receptor expression in comparison with healthy controls (Caragnano et al., 2012). However, a reduction of $\mathrm{P}_{2} \mathrm{X}_{7}$ receptor expression was observed in monocytes from patients undergoing treatment with glatiramer acetate (Copolymer 1, Cop-1, or Copaxone), an immunomodulatory drug used to reduce the frequency of relapses in MS (Caragnano et al., 2012).

In the perfused rat optic nerve, oligodendrocytes are vulnerable to sustained activation of $\mathrm{P}_{2} \mathrm{X}_{7}$ receptors, and this P2X7 receptor-mediated oligodendrocyte death is associated with microgliosis, demyelination, and axonal damage (Matute et al., 2007). Pharmacological blockade of $\mathrm{P} 2 \mathrm{X}_{7}$ receptors of mice with EAE attenuated tissue damage and neurologic symptoms (Matute et al., 2007). Of interest, the incidence of myelin oligodendrocyte glycoprotein (MOG)-induced EAE in mice deficient in $\mathrm{P}_{2} \mathrm{X}_{7}$ receptors was decreased compared with wild-type mice (Sharp et al., 2008). However, once EAE was established in $\mathrm{P}_{2} \mathrm{X}_{7}$ receptor-deficient mice, its severity and course were not different from that of wild-type mice. This indicates that $\mathrm{P}_{2} \mathrm{X}_{7}$ receptors are necessary for the efficient initiation of EAE, but that EAE can occur, albeit at a decreased level, in the absence of $\mathrm{P}^{2} \mathrm{X}_{7}$. In another MOG-induced EAE study, $\mathrm{P}_{2} \mathrm{X}_{7}$ receptor-deficient mice developed more severe clinical and pathologic signs of EAE than wild-type mice and antigen-induced proliferation of spleen and lymph node cells from $\mathrm{P}_{2} \mathrm{X}_{7}$ receptor-deficient mice was increased compared with cells from wild-type mice (Chen and Brosnan, 2006). Further studies will be necessary to explain the conflicting results between these two studies.

An early study showed that $\mathrm{P}_{2} \mathrm{X}_{4}$ receptors were expressed on macrophages infiltrating the brain and spinal cord of rats with EAE (Guo and Schluesener, 2005). $\mathrm{P}_{2} \mathrm{X}_{4}$ receptors are also upregulated on microglia during EAE (Vazquez-Villoldo et al., 2014). Both pharmacological blockade and genetic deficiency exacerbated EAE severity, whereas the $\mathrm{P}_{2} \mathrm{X}_{4}$ allosteric activator Ivermectin (Stromectol), originally an antiparasitic medication, was beneficial, indicating that $\mathrm{P}_{2} \mathrm{X}_{4}$ receptors are protective (Zabala et al., 2018). Mechanistically, $\mathrm{P}_{2} \mathrm{X}_{4}$ receptors favored a switch in microglia to an antiinflammatory phenotype and promoted remyelination.

It is not surprising that of the $\mathrm{P} 2 \mathrm{X}$ receptors, the role of $\mathrm{P}_{2} \mathrm{X}_{7}$ and $\mathrm{P} 2 \mathrm{X}_{4}$ have been studied in detail, as they are expressed at high levels on immune cells (Suurvali et al., 2017; Csóka et al., 2018). The role of other P2X receptors has not been addressed and should be the subject of future studies.

Histologic analysis revealed an increase in the expression of $\mathrm{P} 2 \mathrm{Y}_{11}, \mathrm{P}_{2} \mathrm{Y}_{12}$, and $\mathrm{P}_{2} \mathrm{Y}_{14}$ receptors in the frontal cortex of MS patients (Amadio et al., 2010). The cellular localization of $\mathrm{P}_{2} \mathrm{Y}_{12}$ receptors was studied in detail, and they were found mostly on myelin and interlaminar astrocytes (Amadio et al., 2010). Although the significance of the increase in $\mathrm{P}^{2} \mathrm{Y}_{11}$ and $\mathrm{P}_{2} \mathrm{Y}_{14}$ receptors is unclear, $\mathrm{P}_{2} \mathrm{Y}_{12}$ receptor expression was inversely correlated with myelin lesion formation in patients with MS (Amadio et al., 2010).

In one study, $\mathrm{P}_{12} \mathrm{Y}_{12}$ receptor-deficient mice displayed an exacerbated EAE phenotype (Zhang et al., 2017b). In this model, bone marrow-derived DCs from $\mathrm{P}_{2} \mathrm{Y}_{12}$ knockout mice undergoing EAE released increased amounts of IL-23, an essential factor for the differentiation of $\mathrm{CD}^{+} \mathrm{T}$ cells toward pathogenetic Th17 cells (Zhang et al., 2017b). In another study, EAE was ameliorated in $\mathrm{P}_{2} \mathrm{Y}_{12}$ receptor-deficient mice with decreased brain leukocyte infiltration, less extensive demyelination, and decreased IL-17 expression (Qin et al., 2017). In addition, the anticoagulant drugs clopidogrel ( $\mathrm{P}^{2} \mathrm{Y}_{12}$ inverse agonist, Plavix) and ticagrelor ( $\mathrm{P}_{2} \mathrm{Y}_{12}$ neutral antagonist, Brilinta) alleviated the severity of EAE and inhibited $\mathrm{Th}_{17}$ differentiation (Qin et al., 2017). It is unclear why the two studies had opposing results, as they appeared to use the same mice and model. Therefore, this discrepancy as well as the role of other P2Y receptors awaits further clarification.

Early studies reported that $A_{1}$ receptor mRNA and protein levels were reduced in blood and brain monocytes, macrophages, and microglia from patients with MS (Johnston et al., 2001) and microglia in mice during EAE (Tsutsui et al., 2004). This deficit in $\mathrm{A}_{1}$ receptors appears to contribute to the course of $\mathrm{EAE}$, as $\mathrm{A}_{1}$ receptordeficient mice showed exacerbated disease and had increased myelin and axonal loss (Tsutsui et al., 2004). Macrophages from $\mathrm{A}_{1}$ receptor-deficient mice had increased expression of proinflammatory cytokines and metalloproteinase-12.

Vincenzi et al. (2013) demonstrated increased expression $\mathrm{A}_{2 \mathrm{~A}}$ receptors on lymphocytes from $\mathrm{MS}$ patients compared with healthy individuals (Vincenzi et al., 2013). The authors speculated that this $A_{2 A}$ receptor overexpression is a compensatory mechanism aimed at curbing the inflammatory process, as in vitro stimulation of $\mathrm{A}_{2 \mathrm{~A}}$ receptors of lymphocytes from multiple sclerosis patients suppressed the release of proinflammatory cytokines (TNF, IL- $1 \beta$, IL-6, IL-17, and IFN- $\gamma$ ) and decreased cell proliferation, NF- $\kappa \mathrm{B}$ activation, and the expression of the adhesion molecule VLA-4 (Vincenzi et al., 2013). Positron emission tomography demonstrated increased $\mathrm{A}_{2 \mathrm{~A}}$ receptor expression in the brains of MS patients (Rissanen et al., 2013). At this point it is unclear which cell types were responsible for this increase. 
Increased $\mathrm{A}_{2 \mathrm{~A}}$ receptor expression was also observed on lymphocytes from EAE mice. Pharmacological stimulation of $\mathrm{A}_{2 \mathrm{~A}}$ receptors with the selective agonist CGS21680 starting at the time of immunization with myelin oligodendrocyte glycoprotein (MOG) caused a significant amelioration of EAE clinical severity (Liu et al., 2016). In in vitro cultured lymphocytes from immunized mice, CGS21680 caused a marked decrease in lymphocyte proliferation and $\mathrm{Th}_{1}, \mathrm{Th}_{2}$, and $\mathrm{Th}_{17}$ lymphocyte count and an increase in $\mathrm{T}_{\text {reg }}$ numbers (Liu et al., 2016). Using both pharmacological and genetic manipulation of $\mathrm{A}_{2 \mathrm{~A}}$ receptors in mice with $\mathrm{EAE}$, Ingwersen at al. (2016) demonstrated that while early activation of $\mathrm{A}_{2 \mathrm{~A}}$ receptors ameliorated the course of EAE, $\mathrm{A}_{2 \mathrm{~A}}$ receptor activation after disease onset aggravated the disease process (Ingwersen et al., 2016). In addition, bone marrow transfer studies demonstrated that $\mathrm{A}_{2 \mathrm{~A}}$ receptor expression on nonimmune cells such as neurons in the brain, choroid plexus, meninges, hippocampus, and cerebellum contributed to $\mathrm{EAE}$ development, while $\mathrm{A}_{2 \mathrm{~A}}$ receptor expression on immune cells (most likely lymphocytes) was essential for limiting the severity of the inflammatory response and disease progression (Mills et al., 2012b). A further complicating factor is that $\mathrm{A}_{2 \mathrm{~A}}$ receptors appear to be important for the maintenance of the integrity of bloodbrain barrier, and thereby modulating immune cell influx into the brain (Carman et al., 2011; Kim and Bynoe, 2015; Liu et al., 2018). Thus, the picture is complex and further studies will be required to unravel the precise role of $\mathrm{A}_{2 \mathrm{~A}}$ receptors in EAE.

Similar to $\mathrm{A}_{2 \mathrm{~A}}$ receptors, $\mathrm{A}_{2 \mathrm{~B}}$ receptors are upregulated on peripheral blood leukocytes of MS patients (Wei et al., 2013). $\mathrm{A}_{2 \mathrm{~B}}$ receptor-deficient mice or mice treated with the selective $\mathrm{A}_{2 \mathrm{~B}}$ receptor neutral antagonist CVT-6883 (3-ethyl-3,9-dihydro-1-propyl-8-[1-[[3(trifluoromethyl)phenyl]methyl]-1H-pyrazol-4-yl]-1Hpurine-2,6-dione; 3-ethyl-1-propyl-8-(1-\{[3-(trifluoromethyl)phenyl]methyl\}-1H-pyrazol-4-yl)-2,3,6,7-tetrahydro-1Hpurine-2,6-dione);developed less severe EAE compared with wild-type or vehicle-treated mice, respectively (Wei et al., 2013). This decrease in EAE severity was associated with decreased Th17 and Th1 cell responses in vivo.

Given the central role of CD39 in switching from ATP-mediated proinflammatory responses to the overall anti-inflammatory nature of adenosine-mediated responses (Antonioli et al., 2013c), the role of CD39 in regulating MS is an important question. In an early study, Borsellino et al. (2007) found a strikingly reduced number of $\mathrm{CD}^{+} 9^{+} \mathrm{T}_{\text {regs }}$ in the blood. Fletcher et al. (2009) confirmed this finding, as they observed a deficit in the relative frequency and the suppressive function of $\mathrm{CD}^{+} \mathrm{CD} 25^{+} \mathrm{CD} 127^{\text {low }} \mathrm{FoxP}^{+} \mathrm{CD} 39^{+} \mathrm{T}_{\text {reg }}$ cells in multiple sclerosis patients. Despite these findings, the role of CD39 in modulating the development and course of MS is still elusive. CD39 on DCs was found to be important for limiting the onset and severity of EAE (Mascanfroni et al., 2013) and CD39-deficient CD4 T cells showed an enhanced capability to drive EAE progression (Wang et al., 2014b). Nucleoside, triphosphate diphosphohydrolase-2, which can also degrade ATP, was found to be downregulated in EAE, and this decrease was associated with the severity of disease symptoms (Jakovljevic et al., 2017).

CD73-deficient mice were resistant to EAE, as the entry of lymphocytes into the central nervous system was inhibited in the absence of CD73 (Mills et al., 2008, 2012a). This may be because adenosine generated by CD73 is a key factor for opening the blood-brain barrier and therefore allowing lymphocyte influx (Bynoe et al., 2015).

Despite the observation that CD38 is highly expressed in brain and lymphocytes obtained from MS patients (Penberthy and Tsunoda, 2009), the role of CD38 and the CD38-CD203 axis, is still completely unexplored. Thus, more research is needed to better appreciate the potential relevance of the CD38-CD203 axis in MS pathogenesis and progression.

An increase in adenosine deaminase (ADA) activity was observed in the serum (Polachini et al., 2014) and cerebrospinal fluid (Samuraki et al., 2017) of MS patients. By contrast, ADA enzymatic activity in lymphocytes and platelets was reduced (Vivekanandhan et al., 2005; Spanevello et al., 2010a,b). As no preclinical studies have been performed to study the role of $\mathrm{ADA}$ in regulating MS, the role of these changes in ADA expression and activity is unclear.

Animal models of MS as well as studies performed on samples obtained from MS patients highlighted a key role of purinergic receptors, such as $\mathrm{P}_{2} \mathrm{X}_{7}, \mathrm{P}_{2} \mathrm{Y}_{12}$, or $\mathrm{A}_{2 \mathrm{~A}}$ and $\mathrm{A}_{2 \mathrm{~B}}$ in the onset and progression of this disorder. Indeed, both in vitro and in vivo experiments showed that the pharmacological or genetic manipulation of these receptor subtypes altered disease features, indicating their putative relevance as molecular targets for the development of novel pharmacological entities useful to counteract MS.

\section{B. Uveitis}

Uveitis is an inflammatory condition directed against the uvea, the vascular, pigmented middle coat of the eye wall, composed of the iris anteriorly, the ciliary body intermediately, and the choroid posteriorly (Read, 2006). Uveitis, especially if untreated, can lead to significant visual deficit and blindness (Caspi, 2010). Based on the etiology, uveitis can be distinguished as 1) infectious uveitis caused by an innate inflammatory reaction triggered by environmental "danger" signals (microbial) and 2) noninfectious uveitis, which is believed to be autoimmune or immune mediated (Caspi, 2010; Chen and Sheu, 2017).

The role of $\mathrm{P} 2$ receptors in regulating uveitis is not well understood. Zhao et al. (2016) demonstrated that oxidized ATP (oxATP) almost completely abolished the onset of experimental autoimmune uveitis (EAU) 
elicited by immunization of mice with the human interphotoreceptor retinoid-binding protein peptide IRBP $_{1-20}$ (Zhao et al., 2016). OxATP-treated mice displayed fewer autoreactive $\mathrm{T}$ cells, especially $\mathrm{Th}_{17}$ autoreactive $\mathrm{T}$ cells, indicating that $\mathrm{P} 2 \mathrm{X}_{7}$ receptors promote disease through inducing $\mathrm{Th}_{17}$ cell expansion (Zhao et al., 2016).

The CD2 $5^{+} \mathrm{CD} 11 \mathrm{c}^{+}$DC subset has a critical role in eliciting the $\mathrm{Th}_{17}$ autoreactive $\mathrm{T}$ cell response in $\mathrm{IRBP}_{1-20^{-}}$ elicited EAU, and activated $\gamma \delta \mathrm{T}$ cells promote $\mathrm{Th}_{17}$ cell development (Liang et al., 2012, 2015). Adenosine receptor stimulation differentially affects the immune response depending on the disease stage (Liang et al., 2014). Treating mice with the nonselective adenosine receptor agonist NECA during the induction phase (0 days postimmunization) had a suppressive effect on disease development and $\mathrm{Th}_{17}$ responses (Liang et al., 2014), whereas when administered once the autoimmune response had already been initiated (7 days postimmunization), NECA enhanced disease activity and $\mathrm{Th}_{17}$ responses (Liang et al., 2014). The selective $A_{2 A}$ agonist CGS21680 recapitulated the biphasic effect of NECA, whereas BAY 60-6538 (2-[(3,4-dimethoxyphenyl)methyl]-7-[(1R)-1hydroxyethyl]-4-phenylbutyl]-5-methyl-imidazo[5,1f] $[1,2,4]$ triazin-4(1H)-one), an $\mathrm{A}_{2 \mathrm{~B}}$ agonist, moderately augmented disease activity irrespective of the timing of the treatment (Liang et al., 2014). The stimulatory effect of BAY 60-6538 was confirmed in another study where four injections of this drug between days 0 and 10 postimmunization enhanced EAU development and Th17 cell numbers and IL-17 production (Chen et al., 2015). The enhancing effect of BAY 60-6583 on the $\mathrm{Th}_{17}$ response was markedly reduced in mice lacking $\gamma \delta \mathrm{T}$ cells, suggesting that the proinflammatory effect of BAY 60-6583 required $\gamma \delta$ T cells (Chen et al., 2015)). Since BAY 60-6583 was unable to directly stimulate $\gamma \delta$ T cells but augmented the ability of DCs to activate $\gamma \delta \mathrm{T}$ cells, the authors suggested that the proinflammatory effects of BAY 60-6583 were primarily mediated by $\mathrm{A}_{2 \mathrm{~B}}$ receptors on DCs (Chen et al., 2015). In another EAU model, CGS21680 administered at the peak of EAU accelerated the resolution of disease (Lee et al., 2016). Taken together, exogenous $\mathrm{A}_{2 \mathrm{~A}}$ receptor stimulation can both increase and decrease disease activity in EAU depending on the timing of stimulation and the model used, whereas exogenous $\mathrm{A}_{2 \mathrm{~B}}$ receptor stimulation is proinflammatory across time points and models. In contrast, $\mathrm{A}_{2 \mathrm{~A}}$ receptor $\mathrm{KO}$ and wildtype mice had a comparable course of EAU, indicating that endogenous adenosine stimulating $\mathrm{A}_{2 \mathrm{~A}}$ receptors has no effect on the disease (Lee and Taylor, 2013).

A study performed by Bar-Yehuda et al. (2011) demonstrated that the selective $A_{3}$ receptor agonist CF101 was protective in an experimental animal model of uveitis. CF101 orally administered improved uveitis clinical scores and ameliorated the pathologic manifestations of the disease (Bar-Yehuda et al., 2011). In addition, CF101 acted as an immunomodulatory agent and suppressed antigen-specific proliferation and cytokine production of autoreactive T cells (Bar-Yehuda et al., 2011).

The role of purine metabolic enzymes in regulating uveitis is incompletely defined. CD73 expression was downregulated on $\gamma \delta \mathrm{T}$ cells during the preclinical or immunization phase (before day 7) of uveitis, whereas it was restored later during the clinical phase (Liang et al., 2016a). CD73 on $\alpha \beta$ T cells remained unchanged throughout the course of EAU. As mice lacking $\gamma \delta$ $\mathrm{T}$ cells adoptively transferred with CD73 KO cells had increased clinical score of EAU compared with mice transferred with CD73 sufficient $\gamma \delta \mathrm{T}$ cells, it was concluded that CD73 on $\gamma \delta \mathrm{T}$ cells protect against EAU (Liang et al., 2016a).

In a study aimed at evaluating the role of ADA in EAU, it was observed that ADA suppressed the course of EAU when given 8-14 days postimmunization and increased it when given either before or after this period (Liang et al., 2016b). Mice that received ADA at 8-14 days postimmunization had milder disease and recovered earlier than the untreated animals. In addition, ADA treatment at this time decreased serum IL-6 and IL-17 levels but induced a slight increase in serum IFN- $\gamma$ and IL-10 concentrations (Liang et al., 2016b). The protective role of increased ADA activity at day 8 was confirmed by treating mice with the ADA inhibitor EHNA, which augmented both the course of EAU and IL-17 plasma levels (Liang et al., 2016b). The differential effect of ADA at different time point may reflect the differential role of adenosine receptors described above.

At present, the evidence about the role of the purinergic system in the pathophysiology of uveitis is few and fragmentary and further investigations are needed. In particular, there is a significant knowledge gap of the role of purinergic enzyme machinery in regulating the onset and development of uveitis. Nowadays, the available data indicate encouraging anti-inflammatory effects of adenosine and their agonists CGS21680 and CF101, acting via $\mathrm{A}_{2 \mathrm{~A}}$ and $\mathrm{A}_{3}$ adenosine receptors, respectively, thus prompting their use for the treatment inflammatory ophthalmic conditions. However, future studies are needed to evaluate better the relative contribution of adenosine receptors in shaping the activity of specific immune cells during uveitis.

\section{Myasthenia Gravis}

Myasthenia gravis (MG) is a chronic autoimmune disease caused by antibody-mediated blockade of neuromuscular transmission that results in muscle weakness and fatigue (Conti-Fine et al., 2006). The autoantibodies are generated by $\mathrm{B}$ cells in a $\mathrm{T}$ cell-dependent fashion and are reactive against nicotinic acetylcholine receptors (Vrolix et al., 2010; Meriggioli and Sanders, 2012).

$\mathrm{Li}$ et al. (2012) observed decreased $\mathrm{A}_{2 \mathrm{~A}}$ receptor expression on both $\mathrm{CD} 4^{+} \mathrm{T}$ cells and $\mathrm{B}$ cells residing in spleen and lymph nodes of animals subjected to experimental 
autoimmune myasthenia gravis (EAMG) (Li et al., 2012). The administration of CGS21680 29 days post EAMG induction (therapeutic treatment) ameliorated disease severity and decreased the number of $\mathrm{Th}_{1}$ and $\mathrm{Th}_{2}$ cells while increasing the number of $\mathrm{T}_{\text {reg }}$ cells, thus indicating that targeting $\mathrm{A}_{2 \mathrm{~A}}$ receptors may represent putative therapeutic applications for MG (Li et al., 2012).

A recent paper by Oliveira et al. (2015) proposed that insufficient adenosine levels may contribute to deregulated immune cell function and neuromuscular transmission in myasthenic animals (Fig. 2). In EAMG animals, the expression of CD73 on $\mathrm{T}_{\text {reg }}$ cells was found to be decreased (Oliveira et al., 2015), which may result in impaired suppression of effector $\mathrm{T}$ cells contributing to the disease process ( $\mathrm{Li}$ et al., 2012). In addition, the increased $\mathrm{ADA}$ activity observed in EAMG rats may also potentially aggravate adenosine deficiency and therefore autoimmunity (Oliveira et al., 2015).

In line with what was observed in this EAMG rat model (Oliveira et al., 2015), myasthenic patients showed an increase of total ADA activity (Chiba et al., 1990, 1995).
Of note, the level of ADA2 was positively correlated with clinical MG grade (Chiba et al., 1995). Clearly, further studies aimed at unraveling the role of purinergic signaling in MG are needed.

\section{Rheumatoid Arthritis}

Rheumatoid arthritis (RA) is a common autoimmune disease, which causes both joint inflammation and systemic complications, progressive disability, early death, and high socioeconomic costs (McInnes and Schett, 2011). Macrophages, DCs, T cells, and B cells accumulate in the joints, where they produce autoantibodies, proinflammatory cytokines, and bone destructive mediators (Weyand et al., 2009). Interactions between chronically stimulated immune cells and stromal cells, such as endothelial cells, vascular smooth muscle cells, and synovial fibroblasts are also critical to the onset and progression of this disorder (Weyand et al., 2009).

Extracellular ATP levels are increased in the synovial fluid of RA patients (Dowd et al., 1998). Human synoviocytes were shown to express $\mathrm{P} 2 \mathrm{X}_{1}, \mathrm{P}_{2} \mathrm{X}_{2}, \mathrm{P}_{2} \mathrm{X}_{4}, \mathrm{P}_{2} \mathrm{X}_{5}$,
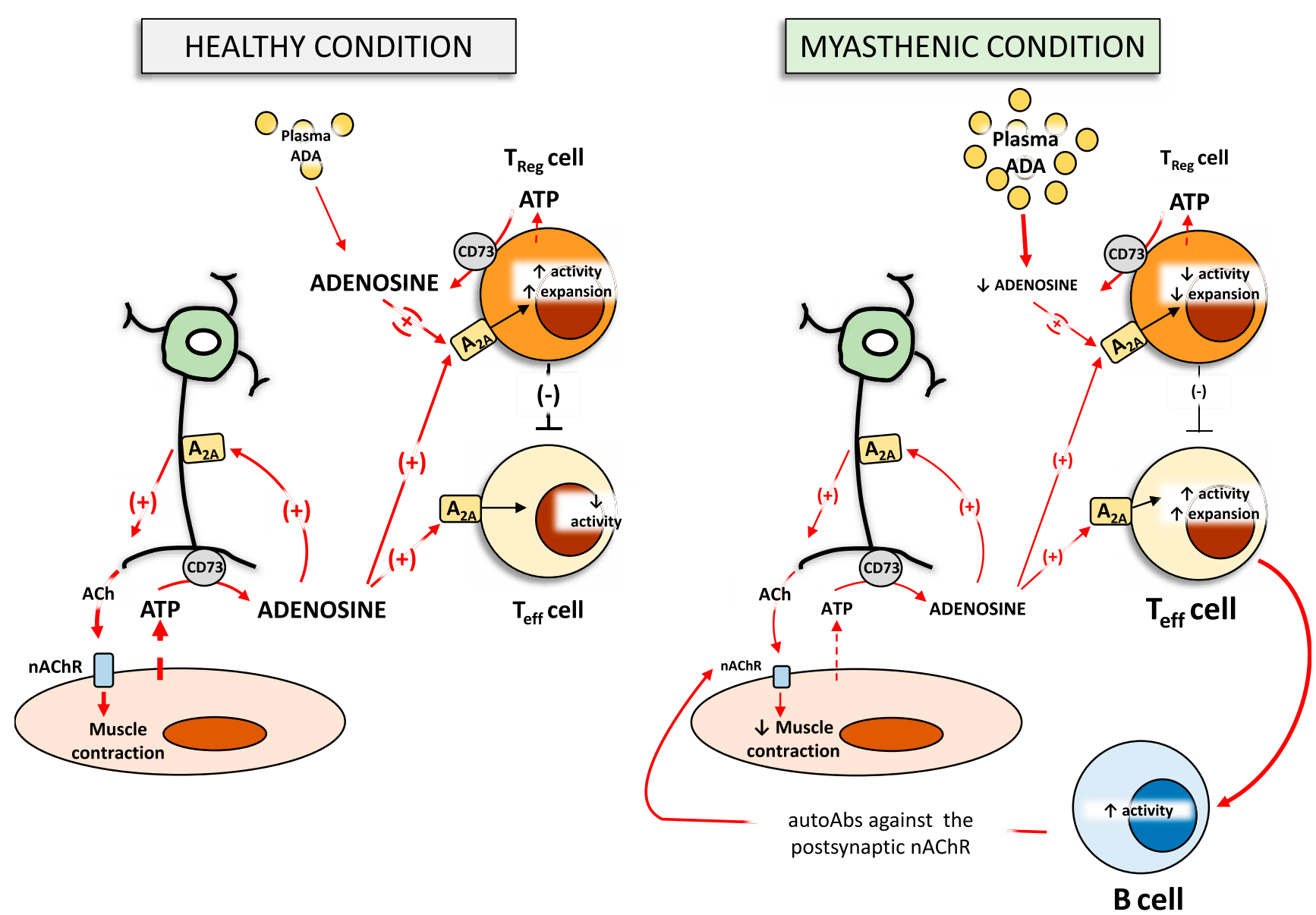

Fig. 2. Schematic representation depicting the role of the purinergic system in neuroimmunological alterations in an experimental model of experimental autoimmune myasthenia gravis. In healthy conditions, endogenous adenosine generated from the activity of CD73 counteracts the proinflammatory activity of $\mathrm{T}_{\text {eff }}$ cells, by acting on $\mathrm{A}_{2 \mathrm{~A}}$ receptor expressed on them and by increasing the activity of $\mathrm{T}_{\text {reg }}$ cells. In addition, in the motor endplate, adenosine, arising from ATP degradation, facilitates acetylcholine release via the stimulation of $\mathrm{A}_{2 \mathrm{~A}}$ receptors expressed at the prejunctional level. In myasthenic animals, there is reduced production of endogenous adenosine. In addition, adenosine degradation is increased, which is related with an increase in plasma adenosine deaminase activity. This results in increased production of autoAbs against nAChR and thus a loss of peripheral tolerance to nAChR. ACh, acetylcholine; ADA, adenosine deaminase; nAChr, nicotinic receptor. 
$\mathrm{P}_{2} \mathrm{X}_{6}$, and $\mathrm{P} 2 \mathrm{X}_{7}$ but not $\mathrm{P} 2 \mathrm{X}_{3}$ receptors at the messenger RNA level (Caporali et al., 2008). Pharmacological studies have shown that $\mathrm{P} 2 \mathrm{X}_{7}$ stimulation on these cells increases the production of IL-6 (Caporali et al., 2008), a major driver of the pathophysiology of RA. In a rat streptococcal cell wall arthritis model, $\mathrm{P}_{2} \mathrm{X}_{7}$ receptor expression was detected in inflamed synovial tissue after the onset of disease, and $\mathrm{P} 2 \mathrm{X}_{7}$ receptor blockade with the selective antagonist AZD9056 suppressed articular inflammation and erosive progression (McInnes et al., 2014). Blockade of $\mathrm{P} 2 \mathrm{X}_{7}$ receptors also ameliorated pathologic changes in a collagen-induced arthritis model in mice, which was associated with decreased differentiation of pathogenic Th17 cells (Fan et al., 2016). Unfortunately, AZD9056 failed to improve clinical outcomes in a phase 2 clinical trial in RA (Keystone et al., 2012). Similarly, CE-224,535 (2-chloro-N-[(1-hydroxycycloheptyl) methyl]-5-[4-[(2R)-2-hydroxy-3-methoxypropyl]-3,5-dioxo1,2,4-triazin-2-yl]benzamide), another $\mathrm{P}_{2} \mathrm{X}_{7}$ receptor antagonist was also not efficacious, compared with placebo, for the treatment of RA in patients with an inadequate response to methotrexate (an allosteric inhibitor of dihydrofolate reductase), a commonly used disease modifying immunosuppressive drug (Stock et al., 2012).

Klein et al. (2012) reported that $\mathrm{P}_{2} \mathrm{X}_{4}$ receptor stimulation increased the release of brain-derived neurotrophic factor, a neuromodulator involved in nociceptive hypersensitivity in the central nervous system, by synoviocytes from RA patients (Klein et al., 2012). The question of whether $\mathrm{P}_{2} \mathrm{X}_{4}$ receptors contribute to pain in RA remains to be investigated. $\mathrm{P}_{2} \mathrm{X}_{4}$ receptors were recently shown to promote joint inflammation and destruction in collageninduced arthritis in mice ( $\mathrm{Li}$ et al., 2014). Mechanistic studies showed that in both synovial cells obtained from human patients with RA and arthritic mice, targeting $\mathrm{P} \mathrm{X}_{4}$ by antisense RNA suppressed the production of the pro-inflammatory cytokines IL- $1 \beta$, TNF, and IL- 6 (Li et al., 2014). In addition, $\mathrm{P}_{2} \mathrm{X}_{4}$ receptor silencing suppressed NLRP1 inflammasome activation (Li et al., 2014).

mRNA for all four adenosine receptors was detected on human synoviocytes (Boyle et al., 1996; Hasko et al., 2008, 2018). Varani et al. (2009) demonstrated increased expression of $\mathrm{A}_{2 \mathrm{~A}}$ and $\mathrm{A}_{3}$ receptors on lymphocytes and neutrophils isolated from RA patients in comparison with healthy subjects. No changes in $\mathrm{A}_{1}$ or $\mathrm{A}_{2 \mathrm{~B}}$ receptors were observed (Varani et al., 2009, 2011; Ravani et al., 2017). The incubation of lymphocytes from RA patients with the selective $A_{2 A}$ and $A_{3}$ receptor agonists CGS 21860 and 2-chloro- $N 6$-(3-iodobenzyl)-adenosine-5' $-N$ methyluronamide (Cl-IB-MECA) respectively, reduced nuclear factor $-\kappa \mathrm{B}$ activation and diminished the release of the pro-inflammatory cytokines TNF- $\alpha$, IL- $1 \beta$, and IL-6 and matrix metalloproteinases MMP-1 and MMP-3 (Varani et al., 2011; Ravani et al., 2017). $\mathrm{A}_{3}$ receptors were found to be highly expressed in inflammatory tissues isolated from rats with adjuvant-induced arthritis, especially synovia, peripheral blood mononuclear cells and draining lymph nodes (Fishman et al., 2006; Rath-Wolfson et al., 2006). $A_{3}$ receptors were also overexpressed in peripheral blood mononuclear cells of RA patients compared with healthy subjects (Madi et al., 2007).

2-(Cyclohexylethylthio) adenosine $5^{\prime}$-monophosphate, a prodrug that is degraded to a selective $A_{2 A}$ receptor agonist by CD73, suppressed joint inflammation in mice with collagen-induced arthritis. The cellular targets of the drug appeared to be monocytes and neutrophils. Interestingly, synovial cytokines were not affected (Flogel et al., 2012).

An early study showed that $A_{3}$ receptor stimulation with N6-(3-iodobenzyl)-adenosine- $5^{\prime}-N$-methyluronamide (IB-MECA also called CF101) reduced the severity of joint inflammation and inhibited the production of MIP-1 $\alpha$, IL-12, and reactive nitrogen species in the paws and suppressed neutrophil infiltration (Szabo et al., 1998). Subsequent studies confirmed the salutary effects of IB-MECA in a rat RA model as well (Bar-Yehuda et al., 2009). Mechanistic studies demonstrated that the anti-inflammatory effects of IB-MECA were associated with reduced expression and activation of phosphoinositide 3-kinase, protein kinase B/Akt, and NF- $\kappa \mathrm{B}$ (Fishman et al., 2006; Ochaion et al., 2008). Despite the promising results with IB-MECA in animal models, it failed to improve the course of RA in human patients (Silverman et al., 2008).

Several studies reported increased CD39 expression on $\mathrm{CD}^{+}{ }^{+} \mathrm{T}$ cells of RA patients (Potocnik et al., 1990; Berner et al., 2000; Dos Santos Jaques et al., 2013). FOXP3 $^{+} \mathrm{CD} 9^{+} \mathrm{T}_{\text {reg }}$ cells are enriched in the joints of patients suffering from RA, and these cells are potent suppressors of many effector T-cell functions, including production of IFN- $\gamma$, TNF- $\alpha$, and IL-17F (Herrath et al., 2014). Although no studies have directly tested the role of CD39 in regulating the course of RA, there is evidence that CD39 mediates the anti-arthritic effects of various treatment modalities. For example, in a murine model of arthritis, CD39 blockade reversed the anti-arthritic effects of methotrexate, a mainstay of RA therapy (Peres et al., 2015). Fructose 1,6-bisphosphate, a high-energy intermediate of glycolysis, also attenuates experimental murine arthritis through CD39 (Veras et al., 2015). Adoptive transfer of human gingiva-derived mesenchymal stem cells ameliorated murine collagen-induced arthritis in a CD39-dependent manner (Chen et al., 2013).

In contrast to CD39, CD73 was downregulated on CD4 ${ }^{+}$ cells and Foxp $3^{+} \mathrm{T}_{\text {regs }}$ at the site of inflammation in patients with RA (Herrath et al., 2014). On the other hand, CD73 was increased on neutrophils and monocytes recovered from the synovial fluid of arthritic mice (Flogel et al., 2012). CD73-deficient mice were found to be more susceptible to collagen-induced arthritis compared with wild-type mice (Chrobak et al., 2015). They had increased 
production of proinflammatory cytokines in their joints and increased Th1 responses. Studies using bone marrow chimeric mice demonstrated that CD73 on non-hematopoietic cells was responsible for the CD73 protection against arthritis (Chrobak et al., 2015).

ADA levels are increased in plasma of patients with RA (Vinapamula et al., 2015; Valadbeigi et al., 2019 and reviewed in Antonioli et al., 2012). Synoviocytes obtained from RA patients had increased ADA mRNA expression (Nakamachi et al., 2003). It is conceivable that increased $\mathrm{ADA}$ is a pathogenic factor, as increased deamination of adenosine will result in its lowered bioavailability and decreased adenosine receptor-mediated suppression of inflammation.

Methotrexate has been in use for the treatment of RA since the 1980s, and it is still often the first line medication for RA patients (Friedman and Cronstein, 2018). There is a large body of evidence that methotrexate mediates its anti-inflammatory effect through increasing ATP release (Morabito et al., 1998; Montesinos et al., 2007), which is subsequently degraded to adenosine through ectonucleotidases (Montesinos et al., 2007), which in turn suppresses inflammation (Montesinos et al., 2000). Recently, it was observed that methotrexate nonresponsiveness in RA patients was associated with low expression of CD39 on $\mathrm{T}_{\text {regs }}$ (Peres et al., 2015; Gupta et al., 2018). This suggests that CD39 expression on $\mathrm{T}_{\text {regs }}$ could be a noninvasive biomarker for the early identification of patients who are unlikely to respond to methotrexate therapy.

Based on the above mentioned evidence a promising novel therapeutic approach for the treatment of RA may involve targeting adenosine receptors (mainly the $\mathrm{A}_{2 \mathrm{~A}}$ and $\mathrm{A}_{3}$ receptor subtypes). Alternatively, indirect targeting of adenosine receptors by enhancing endogenous adenosine concentration at inflamed sites by the pharmacological blockade of ADA or nucleoside transporters, may represent a novel therapeutic approach.

\section{E. Scleroderma}

Scleroderma, which is also called systemic sclerosis, is an autoimmune connective tissue disease characterized by fibrosis of the skin and internal organs as well as by vasculopathy (Denton and Khanna, 2017). Salient features of the tissue lesions in scleroderma are early microvascular damage, mononuclear-cell infiltrates, and slowly developing fibrosis (Gabrielli et al., 2009). In later stages of scleroderma, the main findings are very densely packed collagen in the dermis and other organs, loss of cells, and atrophy (Gabrielli et al., 2009; Denton and Khanna, 2017).

There is a growing body of evidence indicating that adenosine has an important role in tissue remodeling and dermal fibrosis (Chan et al., 2013; Hu et al., 2013; Perez-Aso et al., 2014; Zhang et al., 2017a; KarmoutyQuintana et al., 2018). $\mathrm{A}_{2 \mathrm{~A}}$ receptor activation causes dermal wound closure and increased dermal matrix deposition in vitro (Montesinos et al., 2004; Cronstein, 2006a; Scheibner et al., 2009). In agreement with these in vitro profibrotic effects of $\mathrm{A}_{2 \mathrm{~A}}$ receptor activation, both genetic deletion and pharmacological inhibition of $\mathrm{A}_{2 \mathrm{~A}}$ receptors with ZM241385 (4-[2-(7-amino-2-(2-furyl) [1,2,4-triazolo[2,3-a] [1,3,5]triazin-5-yl-amino]ethyl phenol), a neutral antagonist, prevented dermal fibrosis in mice challenged with subcutaneous bleomycin, a model of human scleroderma (Chan et al., 2006). Another study utilizing a structurally different $\mathrm{A}_{2 \mathrm{~A}}$ antagonist, KW6002 ((E)-8-(3,4-dimethoxystyryl)-1,3-diethyl-7-methylxanthine, 8-[(1E)-2-(3,4-dimethoxyphenyl)ethenyl]-1,3-diethyl-3,7dihydro-7-methyl-1H-purine-2,6-dione), also confirmed reduced severity of bleomycin-induced dermal fibrosis (Zhang et al., 2017a).

Subcutaneous treatment of mice with bleomycin upregulates $\mathrm{A}_{2 \mathrm{~B}}$ receptor transcript levels in the skin (Karmouty-Quintana et al., 2018). Pharmacological blockade of $\mathrm{A}_{2 \mathrm{~B}}$ receptors by GS-6201 reduced the production of profibrotic mediators (fibronectin, MCP1, IL-6, and $\alpha$-SMA) in the skin and attenuated dermal fibrosis of mice in bleomycin-induced as well as genetic [mutant tight-skin (TSK1/+) mice] models of human scleroderma (Karmouty-Quintana et al., 2018). While no differences in $\mathrm{A}_{2 \mathrm{~B}}$ receptor expression were found between healthy and sclerotic human skin (Karmouty-Quintana et al., 2018 ), a reduction in density and function of $A_{2 B}$ receptors was noted in neutrophils of patients affected by scleroderma compared with healthy patients (Bazzichi et al., 2005). The significance of this decrease of $A_{2 B}$ receptor expression and function in scleroderma patients is unclear.

Consistent with the generally profibrotic effects of adenosine, CD39 knockout (KO) animals as well as CD39/CD73 KO exhibited reduced skin fibrosis upon bleomycin challenge (Fernandez et al., 2013).

Genetic deletion of ADA leads to elevated adenosine levels and spontaneous dermal fibrosis in mice (Fernandez et al., 2008). Although increased ADA activity has been reported in plasma of scleroderma patients (Sasaki and Nakajima, 1992; Meunier et al., 1995), it is unclear whether the increased ADA is a causative factor in scleroderma.

In summary, increased adenosine and $\mathrm{A}_{2 \mathrm{~A}}$ and $\mathrm{A}_{2 \mathrm{~B}}$ receptors contribute to scleroderma development in mice. The role of $\mathrm{P} 2$ receptors is unknown and will need to be defined in the future.

\section{F. Psoriasis}

Psoriasis vulgaris, commonly known as plaque psoriasis, is a chronic inflammatory skin disease characterized by skin plaques and systemic symptoms. The immunopathogenesis of psoriasis involves both the innate and adaptive immune systems (Lowes et al., 2014). The immune circuits that normally participate in the regulation of skin homeostasis, become abnormally activated and amplified in psoriatic patients, leading to an excessive and rapid growth of the epidermal layer of the skin 
(Lowes et al., 2014). Activated myeloid DCs release IL-23 and IL-12, which stimulate $\mathrm{Th}_{17}, \mathrm{Th}_{22}$, and $\mathrm{Th}_{1}$ cells to release copious amounts of psoriatic cytokines such as IL-17, IL-22, TNF, and IFN- $\gamma$, which promote keratinocyte hyperproliferation (Lowes et al., 2014).

Keratinocyte express all P2X and P2Y receptor subtypes so far cloned, except for $\mathrm{P}_{2} \mathrm{Y}_{14}$ (Dixon et al., 1999; Burrell et al., 2003; Inoue et al., 2005; Pastore et al., 2007; Ishimaru et al., 2013). IFN- $\gamma$ upregulated the expression of $\mathrm{P}_{2} \mathrm{X}_{7}$ and $\mathrm{P} 2 \mathrm{Y}_{1}$ receptors on human keratinocytes, suggesting a possible involvement of these receptor subtypes in the pathophysiology of psoriasis (Pastore et al., 2007). In line with this view, $\mathrm{P}_{2} \mathrm{X}_{7}$ and $\mathrm{P}_{2} \mathrm{Y}_{1}$ receptors were found to be upregulated in lesional skin of patients with psoriasis (Pastore et al., 2007). An increase in $\mathrm{P}_{2} \mathrm{X}_{7}$ receptor expression was also reported in nonlesional skin of psoriatic patients in comparison with healthy skin tissue, leading the authors to hypothesize that $\mathrm{P}_{2} \mathrm{X}_{7}$ receptor dysregulation in psoriasis precedes the onset of inflammatory lesions (Killeen et al., 2013). In healthy human skin explants, the pharmacological stimulation of $\mathrm{P} 2 \mathrm{X}_{7}$ with BzATP induced a significant increase in vascular endothelial growth factor, IL-23, and IL-6 expression, indicating that $\mathrm{P} 2 \mathrm{X}_{7}$ receptor activation may be an initiating factor in psoriasis development (Killeen et al., 2013).

Although both $\mathrm{P} \mathrm{Y}_{6}$ (Uratsuji et al., 2012) and $\mathrm{P} 2 \mathrm{Y}_{11}$ receptors (Ishimaru et al., 2013) can contribute to proinflammatory responses of keratinocytes in vitro, the relevance of these findings for psoriasis is still incompletely understood.

Normal human keratinocytes and normal human skin express mainly $\mathrm{A}_{2 \mathrm{~B}}$ receptors and detectable levels of $A_{2 A}$ receptors, whereas the levels of $A_{1}$ and $A_{3}$ receptor mRNA are negligible (Andres et al., 2017). Psoriasis is associated with an upregulation of $\mathrm{A}_{2 \mathrm{~A}}$ and downregulation of $\mathrm{A}_{2 \mathrm{~B}}$ receptors in the psoriatic skin (Andres et al., 2017). Since $A_{2 A}$ receptors augment keratinocyte proliferation and $\mathrm{A}_{2 \mathrm{~B}}$ receptors arrest it (Fig. 3) (Andres et al., 2017), it is conceivable that the increase in $A_{2 A}$ and decrease in $\mathrm{A}_{2 \mathrm{~B}}$ receptor expression observed in psoriatic patients contribute the hyperkeratosis process (Fig. 3) (Lowes et al., 2014).

In contrast to keratinocytes, $\mathrm{A}_{2 \mathrm{~A}}$ receptors are downregulated on effector $\mathrm{CD} 4^{+} \mathrm{T}$ cells from patients with psoriasis compared with healthy subjects (Han et al., 2018), while $A_{3}$ receptors are overexpressed in peripheral blood mononuclear cells of psoriatic patients (Ochaion et al., 2009). A randomized, double-blind, placebo-controlled trial demonstrated that IB-MECA improved the clinical symptoms of psoriasis (David et al., 2016). Although this study did not investigate the mechanisms underlying the beneficial effects of IB-MECA, a subsequent study found that $A_{3}$ receptor activation suppressed keratinocyte proliferation and IL-17 and IL-23 production by keratinocytes (Cohen et al., 2018).

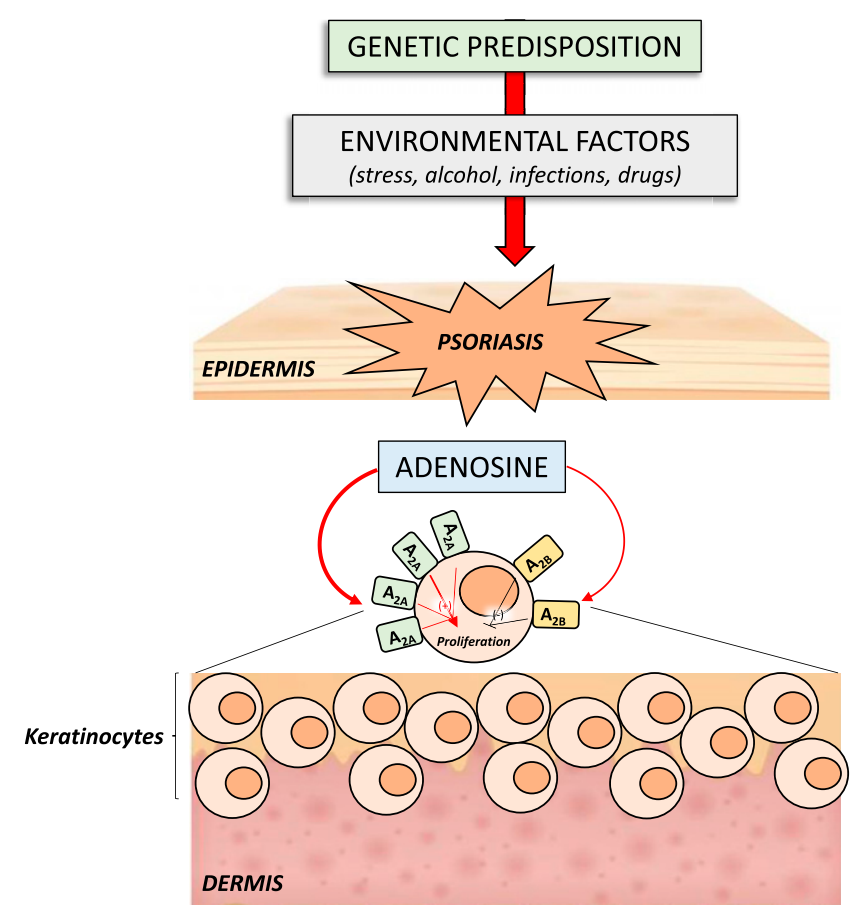

Fig. 3. Role of adenosine in modulating keratinocyte proliferation. Psoriatic patients are characterized by an abnormal hyperproliferation and differentiation of keratinocytes. In this context, endogenous adenosine participates in the hyperkeratosis process by increasing the proliferation of keratinocytes via the engagement of $\mathrm{A}_{2 \mathrm{~A}}$ receptors, which are overexpressed in psoriatic patients.

In conclusion, novel therapies could be derived for hyperproliferative skin diseases, such as psoriasis, based on the intriguing dual roles played by $\mathrm{A}_{2 \mathrm{~A}}$ and $\mathrm{A}_{2 \mathrm{~B}}$ adenosine receptors in modulating keratinocyte proliferation. Future studies should inform us on whether $\mathrm{A}_{2 \mathrm{~A}}$ agonists could be used to reduce inflammation. In addition, it should be of interest to evaluate the influence of existing therapeutic approaches for psoriasis in regulating adenosine receptor expression to determine whether adenosine receptor expression may serve as a biomarker in the trajectory of psoriatic pathology.

\section{G. Systemic Lupus Erythematosus}

Systemic lupus erythematosus (SLE) is a chronic, relapsing/remitting, and multisystemic autoimmune disease with heterogeneous clinical manifestations. The disease can have dermatological, musculoskeletal, renal, respiratory, cardiovascular, hematologic, and neurologic consequences (Moulton et al., 2017). Major pathogenetic factors of SLE comprise immune responses against endogenous nuclear antigens, increased autoantibody production, increased apoptosis, and deficient clearance of apoptotic cells (Moulton et al., 2017). As a result of these processes, immune cells secrete aberrant amounts of cytokines and other soluble proinflammatory mediators, which cause inflammation and the destruction of end-organs (Moulton et al., 2017). The majority of SLE patients display elevated production 
of type I interferons and increased expression of type I IFN-regulated genes (Ronnblom and Pascual, 2008).

There is an increasing appreciation of the notion that alterations of the purinergic machinery can contribute to the pathogenesis of SLE (Forchap et al., 2008; PortalesCervantes et al., 2010; Loza et al., 2011; Sipka, 2011; Saghiri et al., 2012; Bortoluzzi et al., 2016). PortalesCervantes et al. (2010) and Forchap et al. (2008) both studied the role of the most frequent, loss-of-function $1513 \mathrm{~A} \rightarrow \mathrm{C}$ single nucleotide polymorphism of $\mathrm{P} 2 \mathrm{X}_{7}$ receptors in human SLE. Both studies failed to find differences in allele frequencies of this polymorphism when comparing sporadic cases of SLE and healthy controls. Although ATP-induced IL- $1 \beta$ release was significantly decreased in SLE patients with the $1513 \mathrm{~A} \rightarrow \mathrm{C}$ genotype (Portales-Cervantes et al., 2010), the significance of this finding is unclear. In murine studies, pharmacological P2X7 receptor blockade attenuated lupus nephritis, the mechanism of which appeared to be related to decreased NLRP3 inflammasome activation and IL- $1 \beta$ release (Zhao et al., 2013). Le Gall et al. (2012) reported that $\mathrm{B} 220^{+} \mathrm{CD}^{-} \mathrm{CD} 8^{-}$lymphocytes, which accumulate in autoimmune MRL/lpr mice (a murine model characterized by a similar autoantibody profile to SLE patients, with serum antibodies directed against many nuclear antigens, such as DNA and histones) (Mandik-Nayak et al., 1999), became more resistant with age to $\mathrm{P}_{2} \mathrm{X}_{7}$ receptor-induced shedding of CD62L, pore formation, phosphatidylserine exposure, and cell death compared with non-B220 ${ }^{+}$ $\mathrm{CD}^{-} \mathrm{CD}^{-}$lymphocytes (Le Gall et al., 2012). The authors proposed that the decreased $\mathrm{P} 2 \mathrm{X}_{7}$ receptor-mediated cell death of the pathogenetic $\mathrm{B} 220^{+} \mathrm{CD} 4^{-} \mathrm{CD} 8^{-}$population may contribute to disease progression in MRL/lpr mice. Apart from $\mathrm{P} 2 \mathrm{X}_{7}$ receptors, not much is known about the role of $\mathrm{P} 2$ receptors in the pathophysiology of SLE, which should be explored in further studies.

An early report described that adenosine was less efficacious in suppressing $\mathrm{T}$ lymphocyte function in patients with SLE compared with healthy subjects (Mandler et al., 1982). Since $\mathrm{A}_{2 \mathrm{~A}}$ receptors mediate most of the immunosuppressive effects of adenosine on $\mathrm{T}$ cells (Csóka et al., 2008; Himer et al., 2010), this would suggest that $\mathrm{A}_{2 \mathrm{~A}}$ receptor expression or coupling is altered in SLE T cells. Bortoluzzi et al. (2016), however, found higher expression of $\mathrm{A}_{2 \mathrm{~A}} \mathrm{mRNA}$ and protein in lymphocytes from patients with SLE compared with control subjects (Bortoluzzi et al., 2016). $\mathrm{A}_{2 \mathrm{~A}}$ receptor density was inversely correlated with SLE disease activity index (Bortoluzzi et al., 2016). In addition, the $\mathrm{A}_{2 \mathrm{~A}}$ receptor agonist CGS21680 was more efficacious in suppressing $\mathrm{T}$ lymphocyte proinflammatory cytokine production in SLE T lymphocytes than control T lymphocytes. The authors proposed that the upregulation of $\mathrm{A}_{2 \mathrm{~A}}$ receptors on lymphocytes in SLE patients was a compensatory mechanism to counteract the proinflammatory milieu of SLE (Bortoluzzi et al., 2016).
Murine studies confirmed the protective function of $\mathrm{A}_{2 \mathrm{~A}}$ receptors in SLE, as CGS21680 treatment of MRL/lpr mice suppressed $\mathrm{T}$ cell activation, autoantibody production, and renal injury (Zhang et al., 2011). The role of $A_{1}, A_{2 B}$, and $A_{3}$ receptors in SLE is unknown.

CD39 expression was found to be defective on freshly isolated $\mathrm{T}_{\text {reg }}$ cells of lupus subjects with minimally active disease compared with patients with active disease or healthy controls (Loza et al., 2011). In addition, nonregulatory $\mathrm{T}$ cells were deficient in their capacity to upregulate expression of CD39 upon CD3 stimulation specifically in patients with minimally active disease. Although the reason why patients with minimally active disease had defective CD39 remained unclear, the authors proposed that defective CD39 expression might be a useful biomarker for early detection of the disease, prior to the onset of symptoms (Loza et al., 2011). A recent study employing CD39-deficient mice undergoing pristine-induced lupus demonstrated that CD39 controlled autoimmunity and disease symptoms, shedding some light on the role of CD39 in lupus (Knight et al., 2018).

A defective activity was reported also for $5^{\prime}$-nucleotidase in lymphocytes isolated from lupus patients (Stolk et al., 1999). Although this study did not provide more specific evidence, it is likely that the $5^{\prime}$-nucleotidase activity was due to CD73, as this enzyme is the major cell-associated 5 '-nucleotidase (Yegutkin, 2008). Similar to CD39, CD73 protected against pristane-induced lupus (Knight et al., 2018), suggesting that the CD39-CD73-adenosine axis may be important for curbing inflammation in SLE.

\section{H. Glomerulonephritis}

Glomerulonephritis is a condition of glomerular inflammation, which manifests as hematuria and proteinuria (Anders, 2013; Liu and Chun, 2018). It encompasses a spectrum of kidney diseases that collectively are the third leading cause of end-stage renal disease. The incidence of primary glomerulonephritis varies between 0.2 and 2.5 per 100,000 per year (Liu and Chun, 2018). The pathogenesis of glomerulonephritis is complex. Several factors can trigger and contribute to the progression of glomerular injury. These include, but are not limited to, genetic predisposition, autoimmunity, malignancy, infections, diabetes, hypertension, and exposure to drugs (Liu and Chun, 2018). Major pathophysiological factors include glomerular infiltration of macrophages and neutrophils and mesangial cell activation (Scindia et al., 2010; Kitching and Hutton, 2016).

Several P2 receptors are expressed in the healthy kidney (Arulkumaran et al., 2013). Turner et al. (2007) reported that $\mathrm{P} 2 \mathrm{X}_{7}$ receptors were upregulated in the kidney of both patients and mice with glomerulonephritis (Turner et al., 2007). In animal models of antibody-mediated glomerulonephritis, $\mathrm{P}_{2} \mathrm{X}_{7}$ receptor deficiency or pharmacological antagonism prevented macrophage infiltration and protected against kidney 
injury (Taylor et al., 2009). Pharmacological blockade or siRNA-mediated silencing also prevented kidney injury in MRL/lpr mice, a model of lupus-induced glomerulonephritis (Zhao et al., 2013). The protective effect of $\mathrm{P}_{7} \mathrm{X}_{7}$ blockade was associated with decreased NLRP3 inflammasome activation and IL- $1 \beta$ release (Zhao et al., 2013). In a recent murine study, systemic injection of a nanobody against the $\mathrm{P} 2 \mathrm{X}_{7}$ receptors blocked the receptor on $\mathrm{T}$ cells and macrophages and ameliorated antibodyinduced glomerulonephritis (Danquah et al., 2016). Other than the $\mathrm{P}_{2} \mathrm{X}_{7}$ receptor, the only other receptor whose role has been tested in glomerulonephritis is the $\mathrm{P}_{2} \mathrm{Y}_{1}$ receptor, the deficiency of which was protective in mice with antibody-mediated glomerulonephritis (Hohenstein et al., 2007).

Of all the adenosine receptors, the $A_{2 \mathrm{~A}}$ receptor is the only one whose role has been investigated in regulating glomerulonephritis. In the first study on this topic, increased expression of $\mathrm{A}_{2 \mathrm{~A}}$ receptors on macrophages was found in the glomeruli of rats with antibody injection-induced glomerulonephritis (Garcia et al., 2008). Pharmacological activation of $A_{2 A}$ receptors with CGS21680 prevented the infiltration of leukocytes into the kidney, counteracted glomerular inflammation, and protected the kidney from inflammatory injury in this model (Garcia et al., 2008). The protective effect of $\mathrm{A}_{2 \mathrm{~A}}$ receptor stimulation was subsequently confirmed in MRL/lpr mice, as CGS-21680 treatment caused reduced proteinuria, and blood urea and creatinine levels, as well as an improvement in renal histology (Zhang et al., 2011). Renal tissue had reduced macrophage and T-cell infiltration, as well as attenuated MCP-1, IFN- $\gamma$, and MHC-II expression (Zhang et al., 2011). CGS21680 treatment also reduced serum anti-dsDNA levels and renal immune complex deposition (Zhang et al., 2011). A recent study using $A_{2 A}$ receptor $\mathrm{KO}$ mice showed that endogenous adenosine protected mice from glomerulonephritis through $\mathrm{A}_{2 \mathrm{~A}}$ receptors, as the deficient mice were more prone to kidney injury and had increased renal inflammatory cytokines and glomerular hyalinosis compared with wild-type animals (Truong et al., 2016). Using macrophage depletion and reconstitution with wild-type or $\mathrm{A}_{2 \mathrm{~A}}$ receptor-deficient macrophages during the established phase of glomerulonephritis, the authors demonstrated that macrophage $\mathrm{A}_{2 \mathrm{~A}}$ receptors were central to the $\mathrm{A}_{2 \mathrm{~A}}$ receptor-mediated protection against glomerulonephritis (Truong et al., 2016).

\section{Chronic Obstructive Pulmonary Disease}

COPD is a progressive inflammatory condition characterized by a progressive and irreversible deterioration of lung function due to airflow obstruction, destruction of parenchyma, and emphysema (MacNee and Tuder, 2009; Rovina et al., 2013). Tobacco smoking is the most common cause of COPD in the developed world, whereas indoor air pollution due to poorly ventilated cooking fires is a major cause in developing countries (Rovina et al., 2013).
The major pathophysiological factor leading to COPD is airway inflammation caused by the inhaled irritants. The primary target cells of the irritants are epithelial cells and resident (alveolar) macrophages, which become activated and release chemotactic mediators leading to the recruitment of further inflammatory cells $\left(\mathrm{CD} 8^{+}\right.$ T cells, neutrophils, monocytes, and lymphocytes) into the lung. The resulting multicellular infiltrate is central to the maintenance of the chronic inflammatory process, which persists even after the exposure to irritants ceases (Rovina et al., 2013).

There has been a steadily increasing interest in the involvement of purinergic signaling in the pathophysiology of COPD (Polosa and Blackburn, 2009; Mortaz et al., 2010; Pelleg et al., 2016). Lommatzsch et al. (2010) measured ATP concentrations in alveolar bronchoalveolar lavage (BAL) fluid and found that COPD patients had elevated ATP levels compared with controls (Lommatzsch et al., 2010). In patients with COPD, BAL fluid ATP concentrations correlated inversely with lung function and positively with BAL fluid neutrophil counts. BAL fluid macrophages isolated from patients with COPD upregulated their $\mathrm{P}_{2} \mathrm{X}_{7}$ receptor expression compared with control subjects (Lommatzsch et al., 2010). In line with the higher P2X7 receptor expression on macrophages from COPD patients, $\mathrm{P} \mathrm{X}_{7}$ stimulation triggered higher production of proinflammatory cytokines and matrix metalloproteinase 9 by macrophages of patients with COPD compared with macrophages from control subjects (Lommatzsch et al., 2010). In contrast, $\mathrm{P}_{2} \mathrm{X}_{7}$ receptor stimulation on macrophages induced a more pronounced suppression of tissue inhibitor of matrix metalloproteinase-1 release in patients with COPD (Lommatzsch et al., 2010). Since proinflammatory cytokines and matrix metalloproteinase-9 contribute to lung tissue destruction while tissue inhibitor of matrix metalloproteinase-1 prevents it (Daheshia, 2005; Demedts et al., 2005; Churg et al., 2012), the P2X receptor modulation of proinflammatory cytokines and extracellular matrix regulating enzymes appear to be harmful in COPD. Blood neutrophils from COPD patients had upregulated $\mathrm{P}_{2} \mathrm{Y}_{2}$ receptor expression as well as a marked increase in $\mathrm{P}_{2} \mathrm{Y}_{2}$-mediated migration and elastase release compared with neutrophils from healthy subjects (Lommatzsch et al., 2010). Since elastase is important in extracellular matrix degradation (Churg et al., 2012; Bidan et al., 2015), this indicates that $\mathrm{P}_{2} \mathrm{Y}_{2}$ receptors on neutrophils may contribute to lung tissue breakdown.

Murine studies have corroborated the proinflammatory and destructive role of ATP and P2 receptors in COPD. Mice exposed to cigarette smoke had increased $\mathrm{P}_{2} \mathrm{X}_{7}$ receptors primarily in airway macrophages and neutrophils and in lung tissue (Lucattelli et al., 2011). Both pharmacological blockade of $\mathrm{P}_{2} \mathrm{X}_{7}$ with $\mathrm{KN} 62$ and experiments performed using $\mathrm{P}_{2} \mathrm{X}_{7}$ receptor $\mathrm{KO}$ mice revealed a prominent role of this receptor subtype in 
mediating the pro-inflammatory effects of ATP on cigarette smoke-induced lung inflammation and injury (Lucattelli et al., 2011). Similar to observations in human patients (Lommatzsch et al., 2010), $\mathrm{P}_{2} \mathrm{Y}_{2}$ receptors contributed to neutrophil migration in mice (Cicko et al., 2010). In addition, as $\mathrm{P}_{2} \mathrm{Y}_{2}$ receptor-deficient mice had reduced pulmonary inflammation following cigarette smoke exposure, the authors concluded that $\mathrm{P}_{2} \mathrm{Y}_{2}$ receptors may be involved in the pathogenesis of cigarette smoke-induced COPD (Cicko et al., 2010).

Elevated levels of adenosine were detected in the airway lining fluid of patients with COPD compared with normal controls (Polosa, 2002). Using mass spectrometric analysis of exhaled breath condensate, Esther et al. (2011) evaluated AMP and adenosine concentrations on airway surfaces in COPD patients in comparison with healthy smokers and nonsmokers. The results demonstrated elevated airway AMP and adenosine levels in subjects with COPD, which were correlated with several markers of disease severity (Esther et al., 2011).

Adenosine receptors were also found to be altered in COPD patients. That is, in an early study, COPD subjects had decreased affinity but increased density and mRNA expression of $A_{2 A}$ and $A_{3}$ receptors in peripheral lung tissue (Varani et al., 2006). To explain these alterations, the authors speculated that increased adenosine in COPD patients might desensitize $\mathrm{A}_{2 \mathrm{~A}}$ and $\mathrm{A}_{3}$ receptors in the lung, which might result in the compensatory upregulation of these receptors. $A_{1}$ receptor affinity decreased and density increased, but no changes in mRNA expression levels were noted. The affinity of $A_{2 B}$ receptors was not altered, but $\mathrm{A}_{2 \mathrm{~B}}$ receptor density and mRNA expression decreased in peripheral lung tissue of patients with COPD compared with the control group. These inconsistencies with regard to $A_{1}$ and $A_{2 B}$ receptor affinity, density, and mRNA expression in whole lung can potentially be ascribed to the differential expression of $\mathrm{A}_{1}$ and $\mathrm{A}_{2 \mathrm{~B}}$ receptor expression on the various cell types in the lung (Varani et al., 2006). For example, while $\mathrm{A}_{2 \mathrm{~B}}$ receptors were found to be downregulated on macrophages (Varani et al., 2010), $\mathrm{A}_{2 \mathrm{~B}}$ receptor expression was heightened on pulmonary artery smooth muscle cells of COPD patients (Karmouty-Quintana et al., 2013). The clinical significance of these changes in adenosine receptor subtype expression and function in patients with COPD is unclear at this point. Varani et al. (2006) detected a significant correlation between the density and affinity of $\mathrm{A}_{2 \mathrm{~A}}, \mathrm{~A}_{2 \mathrm{~B}}$, and $\mathrm{A}_{3}$ and the forced expiratory volume in one second/forced vital capacity ratio, an established index of airflow obstruction. In a mouse model, $\mathrm{A}_{2 \mathrm{~A}}$ receptor stimulation with CGS21680 was unable to suppress cigarette smokeinduced inflammation (Bonneau et al., 2006; Mantell et al., 2008). Although these findings hint that adenosine receptors may modulate the course of COPD, further studies will be necessary to precisely delineate the role of the various adenosine receptors in regulating the course of COPD in patients.

Aliagas et al. (2018) found decreased CD39 gene and protein expression as well as activity in the lungs of COPD patients in comparison with controls. This decrease in CD39 correlated with higher systemic inflammation and intimal thickening of muscular pulmonary arteries in the COPD group (Aliagas et al., 2018). Immunohistochemical analysis showed that CD39 was downregulated mainly in lung parenchyma, in epithelial bronchial cells, and in the endothelial cells of pulmonary muscular arteries (Aliagas et al., 2018). In contrast, another study demonstrated that CD39 expression and activity were higher in sputa and BAL cells of COPD patients compared with controls (Lazar et al., 2016). Experiments performed on mice chronically exposed to cigarette smoke confirmed increased CD39 in lung tissue (Lazar et al., 2016). In addition, the same study showed that CD39-deficient mice displayed a worsening of lung inflammation induced by both acute and chronic cigarette smoke exposure, which was partially rescued by the administration of apyrase, a CD39 analog. This indicates that CD39 is protective in COPD (Lazar et al., 2016). Another recent study reported increased CD39 expression on peripheral $\mathrm{T}$ cells in patients with acute exacerbations of COPD compared with both COPD patients without exacerbations and healthy controls.

CD73 expression was found to be upregulated and ADA downregulated in lung tissue of patients with COPD (Zhou et al., 2010), indicating that the lung environment in COPD may favor the accumulation of adenosine.

Of note, it will be important to address the role of the purinergic machinery in regulating COPD in more detail. In particular, it would be of interest to investigate how and to what extent the purinergic pathway is involved in the extensive immune dysfunction observed in COPD patients, with particular regard for the role of purines in shaping $\mathrm{CD} 4^{+} \mathrm{PD}-\mathrm{1}^{+}$exhausted effector $\mathrm{T}$ cells, and myeloid-derived suppressor cells, which are involved in COPD pathophysiology.

\section{J. Asthma}

Asthma is a chronic inflammatory disorder of the airways (Colucci et al., 2007). Clinically, asthma is characterized by recurrent episodes of wheezing, breathlessness, chest tightness, and cough. Reversible airway obstruction, mucus overproduction, and bronchial hyperresponsiveness triggered by specific and nonspecific stimuli, such as allergens, chemical irritants, cold air, and exercise underlie the symptoms of asthma (Colucci et al., 2007). Mast cells, eosinophils, Th2 lymphocytes, group 2 innate lymphoid cell types, IgE-producing B lymphocytes, DCs, macrophages, and eosinophils are the key players of the type 2 immune response driving inflammation in asthma (Barnes, 2018). The type 2 immune response is driven primarily by the 
"classical" type 2 cytokines IL-4, IL-5, and IL-13, as well as by the damage-associated cytokines thymic stromal lymphopoietin, IL-25, and IL-33.

ATP accumulates in BAL fluid isolated from patients

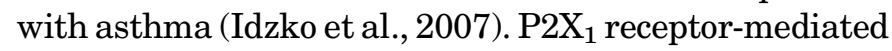
currents and CD11b expression are reduced in in eosinophils from asthma patients compared with healthy controls (Wright et al., 2016). $\mathrm{P}_{7} \mathrm{X}_{7}$ receptors are expressed at higher levels on BAL fluid cells of patients with asthma compared with healthy control subjects (Muller et al., 2011). Eosinophils isolated from asthmatic individuals express higher levels of $\mathrm{P}_{2} \mathrm{Y}_{2}$ receptor compared with healthy controls. As a result, asthmatic eosinophils have increased chemotactic responses and reactive oxygen metabolite production in response to ATP compared with healthy individuals (Muller et al., 2010). A recent genomewide association study identified P2Y13 and P2Y14 as genes associated with asthma risk (Ferreira et al., 2017). Bronchial provocation test with nebulized AMP is an objective test for airway hyperresponsiveness that is clinically useful to aid in the diagnosis of asthma. A study by Basoglu et al. (2005) compared the effect of ATP with that of AMP on airway hyperresponsiveness in patients with asthma. The study demonstrated that ATP was a more potent and efficacious inducer of airway hyperresponsiveness in asthmatic patients than AMP. As ATP but not AMP activates P2 receptors, this finding indicates that $\mathrm{P} 2$ receptors may contribute to the symptoms of asthma in humans (Basoglu et al., 2005).

Preclinical studies also point to a pro-inflammatory role of extracellular ATP and P2 receptors in asthma. Neutralization of ATP using apyrase or pharmacological P2 receptor antagonism with pyridoxalphosphate6-azophenyl-2', $4^{\prime}$-disulfonic acid (PPADS) or oxATP decreased inflammation in an ovalbumin (OVA) model of asthma (Idzko et al., 2007). In contrast, exogenously added ATP promoted sensitization to inhaled OVA in mice (Idzko et al., 2007). Zech et al. (2016) demonstrated that the $\mathrm{P}_{2} \mathrm{X}_{4}$ receptor may be one of the mediators of the proinflammatory effects of ATP in asthma. They showed that both the $\mathrm{P}_{2} \mathrm{X}_{4}$ receptor antagonist 5-BDBD (5-(3-bromophenyl)-1,3-dihydro-2H-benzofuro[3,2-e]1,4-diazepin-2-one) and P2X4 deficiency alleviated BAL fluid eosinophilia, peribronchial inflammation, Th2 cytokine production, and bronchial hyperresponsiveness in a murine OVA asthma model. $\mathrm{P}_{2} \mathrm{X}_{4}$ receptors on DCs were implicated as having a central role in promoting asthma, as adoptive transfer of $\mathrm{P}_{2} \mathrm{X}_{4}$ receptordeficient DCs attenuated the Th2 response and inflammation in OVA-sensitized mice (Zech et al., 2016). P2X receptors also promote asthma in mice. Both mice treated with the AZ9056, a specific $\mathrm{P}_{2} \mathrm{X}_{7}$ receptor-antagonist and $\mathrm{P}_{2} \mathrm{X}_{7}$-deficient mice had reduced features of lung inflammation, such as airway eosinophilia, goblet cell hyperplasia, and bronchial hyperresponsiveness to methacholine in both the OVA model and a house dust mite model of asthma (Muller et al., 2011). Adoptive transfer studies incriminated $\mathrm{P} 2 \mathrm{X}_{7}$ receptor signaling on DCs as a major proinflammatory factor in asthma (Muller et al., 2011).

$\mathrm{P}_{2} \mathrm{Y}_{1}$ receptors were recently shown to be involved in regulating allergic inflammation. Treatment of OVAsensitized mice with the selective and competitive $\mathrm{P}_{2} \mathrm{Y}_{1}$ antagonist $2^{\prime}$-deoxy- $N^{6}$-methyladenosine $3^{\prime}, 5^{\prime}$-bisphosphate (MRS2179) or (1R*,2S*)-4-[2-iodo-6-(methylamino)-9Hpurin-9-yl]-2-(phosphonooxy)bicyclo[3.1.0]hexane-1methanol dihydrogen phosphate ester (MRS2500) inhibited leukocyte recruitment to the lung (Amison et al., 2015). Since platelet depletion followed by reinfusion of platelets preincubated with MRS2500 versus vehicle-preincubated platelets resulted in decreased inflammation, the authors concluded that $\mathrm{P}_{2} \mathrm{Y}_{1}$ receptors on platelets are important for mediating the proinflammatory effects of $\mathrm{P}_{2} \mathrm{Y}_{1}$ receptors. $\mathrm{P}_{2} \mathrm{Y}_{2}$ receptors are also proinflammatory in asthma. In one study, $\mathrm{P}_{2} \mathrm{Y}_{2}$ receptor-deficient mice showed decreased inflammation, decreased IgE levels, decreased VCAM expression on endothelial cells, and defective eosinophil infiltration in OVA-induced asthma (Vanderstocken et al., 2010). In another study, $\mathrm{P}_{2} \mathrm{Y}_{2}$ receptor-deficient mice exhibited reduced allergic inflammation, which was explained by defective inflammatory cell migration into the lung and a reduced Th2 response in lymph nodes (Muller et al., 2010). One study showed that $\mathrm{P}_{12}$ receptors may also contribute to asthma by serving as receptors for LTE4, a major proinflammatory mediator of asthma (Paruchuri et al., 2009). However, a subsequent study questioned the $\mathrm{P}_{2} \mathrm{Y}_{12}$ agonistic role of LTE4 (Foster et al., 2013).

Adenosine receptors have long been implicated in asthma (Polosa and Blackburn, 2009). Theophylline, a competitive nonselective phosphodiesterase inhibitor and also a nonselective adenosine receptor antagonist, has been used to treat asthma for a century (Barnes, 2013). Adenosine concentrations are increased in exhaled breath condensate (Huszar et al., 2002) or BAL fluid (Driver et al., 1993) of patients with asthma compared with healthy subjects. Inhaled adenosine is a potent bronchoconstrictor in human asthma patients but not in healthy subjects (Cushley et al., 1983). These results indicate that adenosine receptors contribute to asthma development and symptoms.

$A_{1}$ receptor expression is increased in bronchial biopsies from patients with asthma versus healthy subjects (Brown et al., 2008b). $\mathrm{A}_{2 \mathrm{~A}}$ receptors are expressed at higher levels on peripheral blood mononuclear cells of patients with mild-to-moderate asthma than healthy patients or patients with severe asthma (Wang et al., 2018a). In sputum, asthma patients had a lower percentage of neutrophils expressing $\mathrm{A}_{2 \mathrm{~B}}$ receptors than healthy subjects (Versluis et al., 2008). $A_{3}$ receptor transcript abundance was greater in lung tissue of asthmatic than in healthy patients (Walker et al., 1997).

Preclinical evidence supports the notion that adenosine signaling participates in the regulation of pulmonary inflammation and damage in asthma (Sun et al., 2006; 
Mohsenin et al., 2007). Mice lacking ADA and therefore having elevated extracellular adenosine levels develop pulmonary inflammation with features typically observed in patients suffering from asthma, such as an increase in alveolar macrophages, airway remodeling, increased mucin production, angiogenesis, and alveolar airway enlargement (Blackburn et al., 2000). Lung-specific IL-13 overexpression in mice produced eosinophil-, lymphocyte-, and macrophage-rich inflammation, alveolar enlargement, mucus metaplasia, and airway hyperresponsiveness on methacholine challenge (Zhu et al., 1999). Blackburn et al. (2003) demonstrated that extracellular adenosine was elevated in these mice and ADA therapy prevented the asthmatic phenotype, indicating that adenosine mediated the proinflammatory effects of IL-13. By crossbreeding adenosine receptor-deficient mice onto the ADA-deficient background, Blackburn and coworkers demonstrated that $\mathrm{A}_{1}, \mathrm{~A}_{2 \mathrm{~A}}$, and $\mathrm{A}_{2 \mathrm{~B}}$ receptors protected against lung inflammation, whereas $\mathrm{A}_{3}$ receptors contributed to it (Young et al., 2004; Sun et al., 2005; Mohsenin et al., 2007; Zhou et al., 2009). The protective role of $\mathrm{A}_{2 \mathrm{~B}}$ receptors, however, was not confirmed using a pharmacological approach in ADAdeficient mice, as pharmacological blockade of $\mathrm{A}_{2 \mathrm{~B}}$ receptors with CVT-6883 starting on postnatal day 24 reduced the number of immune cells in the BAL fluid, decreased the production of pro-inflammatory cytokines and chemokines, and attenuated pulmonary fibrosis (Sun et al., 2006). The reason for the discrepant results of the knockout and pharmacological studies is unclear at this point. One possible explanation is that $\mathrm{A}_{2 \mathrm{~B}}$ receptors affect asthma in a stage dependent manner, where $A_{2 B}$ receptor inactivation from birth may be pro-inflammatory, whereas $\mathrm{A}_{2 \mathrm{~B}}$ receptor blockade initiated after birth may be protective.

Allergen sensitization models have also been helpful in delineating the role of adenosine receptors in asthma. In a ragweed model, $A_{1}$ receptor-deficient mice exhibited decreased IL-5 and ICAM-1 expression and decreased airway hyperresponsiveness, indicating that $\mathrm{A}_{1}$ receptors are proinflammatory in this model (Ponnoth et al., 2010). Pharmacological studies using a selective $A_{1}$ antagonist also pointed to a proinflammatory role of $A_{1}$ receptors in a house dust mite asthma model in rabbits (Obiefuna et al., 2005). $\mathrm{A}_{2 \mathrm{~A}}$ receptor-deficient mice challenged with ragweed had increased inflammation, NF- $\kappa \mathrm{B}$ activation, and airway reactivity to methacholine, indicating that $\mathrm{A}_{2 \mathrm{~A}}$ receptors are protective in this model of asthma (Nadeem et al., 2007). Pharmacological stimulation of $\mathrm{A}_{2 \mathrm{~A}}$ receptors is in general anti-inflammatory, although the protective effects are variable. After repeated ovalbumin challenges in mice, intranasally administered CGS21680 inhibited BAL fluid inflammatory cell influx but had no effect on OVAinduced bronchoconstriction and airway hyperreactivity (Bonneau et al., 2006). In another murine OVA model, CGS21680 upregulated the $\mathrm{T}_{\text {reg }}$ transcription factor FoxP3 and the $\mathrm{T}_{\text {reg }}$-derived cytokine TGF- $\beta$, decreased the Th-17-related transcription factor ROR- $\gamma \mathrm{T}$ and IL-17, and improved lung function (Wang et al., 2018a). The anti-inflammatory effects of $\mathrm{A}_{2 \mathrm{~A}}$ agonism in mice were not borne out in a human clinical trial, as the selective $\mathrm{A}_{2 \mathrm{~A}}$ agonist GW328267X failed to affect the inflammatory response and airway hyperresponsiveness in patients with asthma (Luijk et al., 2008).

Genetic ablation of $\mathrm{A}_{2 \mathrm{~B}}$ receptors in mice attenuated OVA-induced chronic pulmonary inflammation, IL-4 and TGF- $\beta$ production, and pulmonary inflammation and injury (Zaynagetdinov et al., 2010), indicating that $\mathrm{A}_{2 \mathrm{~B}}$ receptors contribute to the pathophysiology of asthma. Similarly, both global and myeloid $A_{2 B}$ receptor deficiency decreased pulmonary inflammation, Th2 cytokine production, and chemokine level in a cockroach-allergen murine model (Belikoff et al., 2012). Pharmacological studies with a selective $A_{2 B}$ receptor antagonist confirmed the proinflammatory role of $A_{2 B}$ receptors in murine asthma (Basu et al., 2017a,b). Using both $\mathrm{A}_{3}$ receptor-deficient mice and treatment with IB-MECA, Young et al. (2006) demonstrated that $\mathrm{A}_{3}$ receptors contribute to airway mucin secretion after OVA challenge of mice. However, pulmonary inflammation and function were not determined in this study.

The purinergic enzyme machinery also influences the course of asthma. Asthma patients have decreased proportions of CD39 ${ }^{+} \mathrm{T}_{\text {regs }}$ among all $\mathrm{T}_{\text {regs }}$ compared with healthy individuals (Wang et al., 2013). CD39 mRNA levels in both $\mathrm{CD}^{+} \mathrm{T}$ cells (Wang et al., 2013) and peripheral blood mononuclear cells are decreased in asthma patients versus healthy subjects (Wang et al., 2014a). This suggests that insufficient CD39-mediated immune suppression may contribute to the progression of asthma. Surprisingly, mice lacking CD39 displayed a milder asthma phenotype than wild-type mice when tested in both the OVA and house dust mite models (Idzko et al., 2013). This decrease in asthma severity in the CD39-deficient mice was due to aberrant migration of DCs with a consequent limitation of the capacity of these cells to prime $\mathrm{Th}_{2}$ responses (Idzko et al., 2013).

Similar to CD39, the proportions of $\mathrm{CD}^{+} 3^{+} \mathrm{T}_{\text {regs }}$ among all $\mathrm{T}_{\text {regs }}$, as well as CD73 mRNA expression in $\mathrm{CD} 4^{+} \mathrm{T}$ cells was lower in asthmatic patients than in healthy subjects (Wang et al., 2013). The role of CD73 in regulating asthma remains to be determined.

\section{K. Inflammatory Bowel Diseases}

IBDs, such as Crohn's disease and ulcerative colitis, are chronic relapsing disorders of the gastrointestinal tract. They are characterized by intestinal inflammation and epithelial injury (Neurath, 2014). Major symptoms include abdominal pain, diarrhea, bloody stool, malabsorption, and weight loss (Huang and Chen, 2016). Patients with IBD often suffer from other autoimmune diseases as well, such as primary sclerosing cholangitis, psoriasis, and ankylosing spondylitis 
(Huang and Chen, 2016). Deregulated immune responses in the intestinal mucosa are critical factors that precipitate the onset of IBDs (Neurath, 2014). IBD patients have both altered $\mathrm{T}$ cell homeostasis and antigenpresenting cell dysfunction (Neurath, 2014). $\mathrm{Th}_{1}$ and $\mathrm{Th}_{17}$ cells and other IL-17 and IFN- $\gamma$-producing cells are major pathogenic contributors to the intestinal inflammatory manifestations of IBD (Neurath, 2014). IL-12 and IL-23, produced predominantly by DCs and macrophages, are major drivers of the development and activation of $\mathrm{Th}_{1}$ and $\mathrm{Th}_{17}$ cells, respectively (Neurath, 2014). The intestinal mucosal epithelium is also involved in the pathophysiology of IBD. Its barrier function is compromised, leading to increased permeability to noxious intraluminal agents, such as bacteria. Bacteria crossing the intestinal barrier activate the mucosal immune system and drive inflammation (Turner, 2009; Cahenzli et al., 2013; Martini et al., 2017).

Purinergic pathways are important for the maintenance of intestinal homeostasis by shaping the communication among luminal bacteria, epithelial cells, and the enteric immune system. High levels of extracellular ATP are commonly observed in the presence of intestinal inflammation (Wan et al., 2016; Lanis et al., 2017). ATP is released from damaged intestinal epithelial cells (Kurashima et al., 2015) as well as from immune/ inflammatory cells, including neutrophils (Dosch et al., 2018) and macrophages (Sakaki et al., 2013). Another source of extracellular ATP is the intestinal commensal flora (Atarashi et al., 2008; Inami et al., 2018). ATP released from intestinal commensal bacteria participates in enteric homeostatic regulatory mechanisms by inducing the differentiation of naturally occurring $\mathrm{Th}_{17}$ cells, which control bacterial and fungal infections at the mucosal surface (Atarashi et al., 2008). ATP released from commensal bacteria is also important for the maintenance of host-microbiota mutualism. That is, ATP, through $\mathrm{P}_{2} \mathrm{X}_{7}$ receptor activation on $\mathrm{T}$ follicular helper cells, limits the secretory IgA response to commensal bacteria in the small intestine, thereby leading to the selection of a beneficial commensal microbial community for the host (Proietti et al., 2014; Perruzza et al., 2017).

$\mathrm{P} 2 \mathrm{X}_{7}$ receptors are upregulated in both the intestinal epithelial layer and the lamina propria of patients with both Crohn's disease and ulcerative colitis (Neves et al., 2014). In the inflamed lamina propria of patients with IBD, $\mathrm{P} 2 \mathrm{X}_{7}$ receptors colocalize mainly with DCs and to a lesser extent with macrophages and T cells (Neves et al., 2014).

Studies performed in a $\mathrm{T}$ cell-mediated chronic colitis mouse model highlighted the relevance of $\mathrm{P} 2 \mathrm{X}_{7}$ receptors in stimulating T-cell conversion into $\mathrm{Th}_{17}$ cells (Schenk et al., 2008). That is, repeated administration of oxATP, a P2X $\mathrm{X}_{7}$ antagonist, mitigated the intestinal inflammatory process, promoting the cell-autonomous conversion of naive $\mathrm{CD} 4^{+} \mathrm{T}$ cells into $\mathrm{T}_{\text {regs }}$ after TCR stimulation (Schenk et al., 2008, 2011). In addition, adoptive transfer of $\mathrm{P}_{2} \mathrm{X}_{7}$ receptor-deficient $\mathrm{T}_{\text {regs }}$ but not wild-type $\mathrm{T}_{\text {regs }}$ protected lymphopenic CD3e $\mathrm{e}^{-/-}$mice from colitis induced by adoptive transfer of naive CD45. $1^{+} \mathrm{CD}^{+} \mathrm{T}$ cells (Schenk et al., 2011).

Rats with trinitrobenzene sulfonic (TNBS) acid-induced colitis treated with the $\mathrm{P} 2 \mathrm{X}_{7}$ receptor antagonists A740003 [N-(1-\{[(cyanoimino)(5-quinolinylamino) methyl] amino\}2,2-dimethylpropyl)-2-(3,4-dimethoxyphenyl)acetamide] before colitis induction had improved disease scores and decreased inflammation compared with rats treated with vehicle (Marques et al., 2014). $\mathrm{P}_{2 \mathrm{X}}$ receptordeficient mice were less susceptible to TNBS- or dextran sulfate-sodium (DSS)-induced colitis than wild-type animals (Neves et al., 2014; Hofman et al., 2015; Figliuolo et al., 2017). The beneficial effect of $\mathrm{P}_{2} \mathrm{X}_{7}$ receptor deficiency in these studies was associated with decreased production of inflammatory cytokines, decreased NF- $\kappa \mathrm{B}$, activation and $\mathrm{T}_{\text {reg }}$ accumulation (Neves et al., 2014; Hofman et al., 2015; Figliuolo et al., 2017). A study using mice with TNBS-induced colitis demonstrated a critical role of $\mathrm{P} 2 \mathrm{X}_{7}$ receptors on mast cells in the development of colitis, as mast cell-deficient mice reconstituted with $\mathrm{P} 2 \mathrm{X}_{7}$-knockout mast cells had decreased intestinal inflammation compared with mice reconstituted with wild-type mast cells (Kurashima et al., 2012). Clinically, a marked increase in $\mathrm{P}_{2} \mathrm{X}_{7}^{+}$mast cell numbers was observed at sites of inflammation in Crohn's disease patients (Kurashima et al., 2012). Interestingly, despite decreased inflammation, $\mathrm{P}_{2} \mathrm{X}_{7}$ receptor-deficient mice exhibited increased tumor incidence in a model of colitisassociated cancer (Hofman et al., 2015). The increase in tumor formation was secondary to increased intestinal epithelial proliferation, decreased apoptosis, and increased production of TGF $\beta 1$. Although most of these studies support a proinflammatory role for $\mathrm{P}_{2} \mathrm{X}_{7}$ receptors in colitis, this was not borne out in a clinical study. In a placebo-controlled, multicenter, double-blind phase IIa study, Crohn's patients treated with the $\mathrm{P} 2 \mathrm{X}_{7}$ receptor antagonist AZD9056 showed no amelioration in inflammation although the Crohn's Disease Activity Index was decreased in drug versus placebo-treated patients (Eser et al., 2015).

$\mathrm{P} 2 \mathrm{X}_{3}$ receptors were upregulated in patients with IBD (Yiangou et al., 2001). $\mathrm{P} 2 \mathrm{X}_{3}$ receptors were only detected in neurons of the myenteric and submucosal plexuses. The authors hypothesized that $\mathrm{P}_{2} \mathrm{X}_{3}$ receptors may be involved in pain and dysmotility in IBD.

$\mathrm{P}_{2} \mathrm{Y}_{2}$ receptors are increased in colonic tissues of IBD patients (Grbic et al., 2012). In addition, both TNF- $\alpha$ and IFN- $\gamma$ upregulated $\mathrm{P}_{2} \mathrm{Y}_{2}$ receptors in the intestinal epithelium (Grbic et al., 2008). Stimulation of P2Y2 receptors with the agonist 2 -thiouridine- 5 '-triphosphate promoted recovery from colitis in DSS-treated mice, which was mostly due to increased regeneration of the intestinal epithelium (Degagne et al., 2013). $\mathrm{P}_{2} \mathrm{Y}_{6}$ receptors were shown to be upregulated on $\mathrm{T}$ cells 
infiltrating the colon of patients with active IBD (Somers et al., 1998). Both genetic and pharmacological blockade of $\mathrm{P} 2 \mathrm{Y}_{12}$ receptors ameliorated TNBS-induced colitis in mice (Qin et al., 2017), indicating that $\mathrm{P}_{2} \mathrm{Y}_{12}$ receptors may be targets for intervention in human IBD.

$\mathrm{A}_{2 \mathrm{~A}}$ receptor mRNA expression in colonic mucosa obtained from Crohn's patients with active disease was found to be enhanced, while no changes were detected in ulcerative colitis patients (Rybaczyk et al., 2009). In contrast, in a recent study, Tian et al. (2016) demonstrated reduced expression of $\mathrm{A}_{2 \mathrm{~A}}$ receptor mRNA and protein in sigmoid colonic mucosa obtained from active ulcerative colitis patients compared with normal controls. Of note, $\mathrm{A}_{2 \mathrm{~A}}$ protein expression was inversely correlated with the expression of miR-16 (Tian et al., 2016). Results obtained using both in silico data as well as functional studies showed that miR-16 targeted the 3 '-untranslated region of $\mathrm{A}_{2 \mathrm{~A}}$ receptor mRNA, resulting in inhibition of $\mathrm{A}_{2 \mathrm{~A}}$ receptor transcription (Tian et al., 2016). Preclinical studies revealed a critical role of $A_{2 A}$ receptors in controlling the function $\mathrm{T}$ cells that regulate colitis. In an early study using a colitis model in which adoptive transfer of pathogenic CD45RB ${ }^{\text {high }} \mathrm{Th}$ cells into severe combined immunodeficient mice causes colitis, it was found that co-transfer of CD45RB ${ }^{\text {low }}$ or $\mathrm{CD}^{2} 5^{+}$Th cells lacking $\mathrm{A}_{2 \mathrm{~A}}$ receptors failed to prevent disease, whereas wild-type CD45RB ${ }^{\text {low }}$ or $\mathrm{CD}^{+} 5^{+} \mathrm{Th}$ cells did prevent disease (Naganuma et al., 2006). In a more recent pharmacological study, systemically administered inosine was protective against TNBS-induced colitis, and the protective effects were shown to be mediated by $\mathrm{A}_{2 \mathrm{~A}}$ receptors (Rahimian et al., 2010). Systemic administration of the selective $A_{2 A}$ receptor agonist CGS21680 was, however, not protective in mice with DSS-induced colitis (Selmeczy et al., 2007). In contrast, oral administration of the poorly absorbed $\mathrm{A}_{2 \mathrm{~A}}$ receptor agonist PSB-0777 was anti-inflammatory and protective in a rat model of oxazolone-induced colitis (Antonioli et al., 2018). Thus, the systemic effects of $A_{2 A}$ receptor stimulation may offset its local protective effects. Of note, $\mathrm{A}_{2 \mathrm{~A}}$ receptors have also been shown to control the neuroplastic changes occurring in the inflamed gut (Antonioli et al., 2006). Thus, it was proposed that $\mathrm{A}_{2 \mathrm{~A}}$ agonists may be useful to stem enteric motor dysfunctions, which are typically observed in IBD patients (Antonioli et al., 2006, 2011).

The gut expresses high levels of $\mathrm{A}_{2 \mathrm{~B}}$ receptors with intestinal epithelial cells as major contributors (Hasko et al., 2009; Colgan et al., 2013). A marked upregulation of $\mathrm{A}_{2 \mathrm{~B}}$ receptor expression was observed in the intestinal mucosa during both human and murine colitis, and $\mathrm{A}_{2 \mathrm{~B}}$ receptor expression was highest in intestinal epithelial cells (Kolachala et al., 2005). In this context, $A_{2 B}$ receptors have been shown to modulate several epithelial cell functions, such as secretory activity, barrier function, and interaction with bacteria, which are all important factors in IBD (Kolachala et al., 2005). $\mathrm{A}_{2 \mathrm{~B}}$ receptors are also expressed on endothelial cells and macrophages (Yang et al., 2006). Early studies by one group using both genetic knockout mice and pharmacological blockade indicated that $\mathrm{A}_{2 \mathrm{~B}}$ receptors contribute to the severity of symptoms and inflammation of colitis in mice (Kolachala et al., 2008a,b). Subsequently, another group found that both general $\mathrm{A}_{2 \mathrm{~B}}$ receptor knockout and pharmacological blockade augmented the course of colitis and suppressed inflammation, indicating a protective role for $\mathrm{A}_{2 \mathrm{~B}}$ receptors (Frick et al., 2009). Using intestinal epithelial cellspecific $A_{2 B}$ receptor deficient mice, the same group then went on to show that $A_{2 B}$ receptors on epithelial cells are important for protection against colitis, suppression of inflammation, and gut barrier function (Aherne et al., 2015). Potential explanations for why the two groups found opposing roles for $\mathrm{A}_{2 \mathrm{~B}}$ receptors include details in the colitis protocols, differences in murine strains with genetic deletion of the $\mathrm{A}_{2 \mathrm{~B}}$ receptors, and differences in housing conditions, including potential differences in the bacterial flora of the mice (Frick et al., 2009).

Decreased expression of $\mathrm{A}_{3}$ receptors was reported in colorectal mucosa from patients with ulcerative colitis (Rybaczyk et al., 2009; Wu et al., 2017) and in animal models of intestinal inflammation (Rybaczyk et al., 2009; Ren et al., 2011). In contrast, $A_{3}$ receptor was overexpressed in peripheral blood mononuclear cells of Crohn's patients (Ochaion et al., 2009). IB-MECA treatment of mice with DSS-induced colitis and IL-10 deficiencyinduced colitis (Mabley et al., 2003) or rats with TNBSinduced colitis prevented the clinical symptoms and histologic signs of inflammation and suppressed inflammation (Guzman et al., 2006). Counterintuitively, $\mathrm{A}_{3}$ receptor-deficient mice were protected against DSSinduced colitis (Ren et al., 2011). Such apparent discrepancies can potentially be explained by the heterogeneous experimental conditions used in the above-mentioned studies. For example, genetic deletion of $\mathrm{A}_{3}$ adenosine receptors may cause compensatory upregulation of other receptor subtypes, i.e., the $\mathrm{A}_{2 \mathrm{~A}}$, which would then exert protective effects in intestinal inflammation (Naganuma et al., 2006). Alternatively, it is possible that the differential results may be due to differences in the bacterial flora among the various studies, as the bacterial flora is an important factor in colitis (Guarner and Malagelada, 2003).

The CD39/CD73 axis has emerged as a potential pharmacological target in IBD. In humans with IBD, CD39 expression on $\mathrm{T}_{\text {regs }}$ was lower compared with healthy patients (Gibson et al., 2015). CD39 expression on $\mathrm{T}_{\text {regs }}$ increased after treatment with the anti-TNF- $\alpha$ antibody infliximab (Gibson et al., 2015). Bai et al. (2014) described a human Th17 subpopulation with suppressor activity, which expresses high levels of CD39 and consequently produces extracellular adenosine (Bai et al., 2014). These uniquely suppressive CD $39^{+} \mathrm{Th} 17$ cells are decreased in patients with IBD (Bai et al., 2014). $\mathrm{CD} 39^{+} \mathrm{CD} 8^{+} \mathrm{T}$ cells were significantly increased in 
peripheral blood and lamina propria of patients with active Crohn's disease compared with healthy donors (Bai et al., 2015). Similar to CD39 ${ }^{+}$Th17 cells, CD39 ${ }^{+} \mathrm{CD}^{+}$ $\mathrm{T}$ cells exert immunosuppressive effects through the generation of extracellular adenosine (Bai et al., 2015). A single nucleotide polymorphism tagging low levels of CD39 expression was associated with increased susceptibility to Crohn's disease in a case-control cohort comprising 1748 Crohn's patients and 2936 controls (Friedman et al., 2009). Overall, these results suggest a protective role for CD39 in human patients with IBD.

The role of CD39 in mouse models is controversial. In an early study, CD39-deficient mice exhibited increased susceptibility to DSS-induced colitis, which was rescued by exogenously introduced apyrase (Friedman et al., 2009). In addition, unconjugated bilirubin protected against DSS-induced colitis through upregulating CD39 on Th17 cells (Longhi et al., 2017). In another study, employing mice with TNBS-induced colitis CD39 deficiency was protective (Kunzli et al., 2011). In the same study, the severity of oxazolone-induced colitis was similar in CD39 deficient and wild-type mice (Kunzli et al., 2011). The authors posited that one explanation for the different observations in the two models is that while the TNBS model exhibits clinicopathological findings that are more similar to Crohn's disease, oxazoloneinduced colitis has features similar to ulcerative colitis (Boirivant et al., 1998). Clearly, further studies using mice with cell-specific and temporal targeting of CD39 will be necessary to resolve the role of CD39 in colitis.

In the intestinal mucosa, CD73 appears to have a critical role in maintaining homeostasis (Synnestvedt et al., 2002; Colgan et al., 2006; Louis et al., 2008; Sotnikov and Louis, 2010). In patients with IBD, increased numbers of $\mathrm{CD} 73^{+} \mathrm{CD} 4^{+} \mathrm{T}$ cells in the periphery and lamina propria were noted during active inflammation, which returned to baseline levels following anti-TNF treatment (Doherty et al., 2012). Similar to observations with CD39 noted above (Bai et al., 2014), the $\mathrm{CD} 73^{+} \mathrm{CD} 4^{+} \mathrm{T}$-cell population in patients with active IBD were enriched with cells with a T-helper type 17 phenotype (Doherty et al., 2012).

There is a marked induction of colonic mucosal CD73 expression in response to TNBS-induced colitis in mice (Louis et al., 2008). CD73-deficient mice with TNBSinduced colitis showed a worsening of clinical course and inflammation severity (Louis et al., 2008). In addition, in mice with TNBS-induced colitis the selective CD73 inhibitor $\alpha, \beta$-methylene $\mathrm{ADP}$ increased colitis severity (Louis et al., 2008). Since IFN- $\alpha$ A was downregulated in colitis and exogenous IFN- $\alpha \mathrm{A}$ reversed the deleterious CD73 phenotype, the authors argued that CD73 protects against colitis through inducing IFN- $\alpha$ A. Similar to results with the TNBS model of colitis, CD73 was also protective in the DSS model (Bynoe et al., 2012). When pathogenic $\mathrm{CD}^{+} \mathrm{CD}^{-} \mathrm{RB}^{\text {high }}$ cells were adoptively transferred to
Rag deficient mice, cotransfer of wild-type $\mathrm{T}_{\text {regs }}$ was as protective as cotransfer of CD73-deficient $\mathrm{T}_{\text {regs }}$ (Bynoe et al., 2012). Thus it was concluded that CD73 expression on $\mathrm{T}_{\text {regs }}$ was not needed for protection.

Several studies have been performed to evaluate the role of ADA in the pathophysiology of IBDs (Antonioli et al., 2012). Serum obtained from Crohn's patients during active disease had increased total ADA and ADA2 levels compared with both patients in remission and healthy subjects (Maor et al., 2011). Increased expression of ADA was also detected in murine models of intestinal inflammation (Antonioli et al., 2010a, 2014). In addition, pharmacological blockade of ADA ameliorated IBD in rodent models (Antonioli et al., 2007, 2010a; Brown et al., 2008a; La Motta et al., 2009), Thus ADA may serve as both a disease marker and therapeutic target in IBD.

In colonic tissue obtained from IBD patients, ENT1, ENT2, and CNT2 mRNA levels were higher in comparison with control specimens (Wojtal et al., 2009) (Fig. 4). A recent study by Aherne et al. (2018) demonstrated that the administration of dipyridamole, a pharmacologic blocker of ENT 1 and ENT2, protected mice against DSS-induced colitis. Of note, the genetic loss of Ent1 failed to alter the outcome of DSS colitis in mice, whereas animals with global or mucosal Ent2 deletion were protected against intestinal inflammation, suggesting a detrimental role for ENT2 during experimental colitis (Aherne et al., 2018). Mechanistic studies demonstrated that ENT2 inhibition or deficiency increased extracellular adenosine levels, which were protective through $\mathrm{A}_{2 \mathrm{~B}}$ receptor activation (Aherne et al., 2018).

At present, several lines of preclinical evidence support the possibility of encouraging beneficial effects resulting from the pharmacological modulation of purinergic pathways in bowel inflammation. In particular, $\mathrm{A}_{2 \mathrm{~A}}$ and $A_{3}$ receptor agonists were effective in curbing several digestive dysfunctions typically associated with IBDs, such as visceral pain, diarrhea, ischemia, and functional disorders. However, despite these promising results, several issues pertaining to the regulation of digestive functions by the purinergic system remain unexplored and deserve further investigations.

\section{Future Directions}

Based on evidence reviewed here, we propose that IMIDs share molecular alterations of some of the key elements of the purinergic machinery. Some of these alterations are shared across a wide variety of IMIDs and include downregulation of $\mathrm{A}_{2 \mathrm{~A}}$ receptors on effector $T$ cells, upregulation of $\mathrm{A}_{2 \mathrm{~A}}$ and $\mathrm{A}_{3}$ receptors on PBMCs, upregulation of $\mathrm{P}_{2} \mathrm{X}_{7}$ receptors on effector T cells, increased ADA levels, and reduced activity of the CD39/ CD73 enzyme axis on the surface of $\mathrm{T}_{\text {regs }}$ (Fig. 5). Thus it is possible that targeting these key purinergic nodes may be a worthy strategy for drug development to 

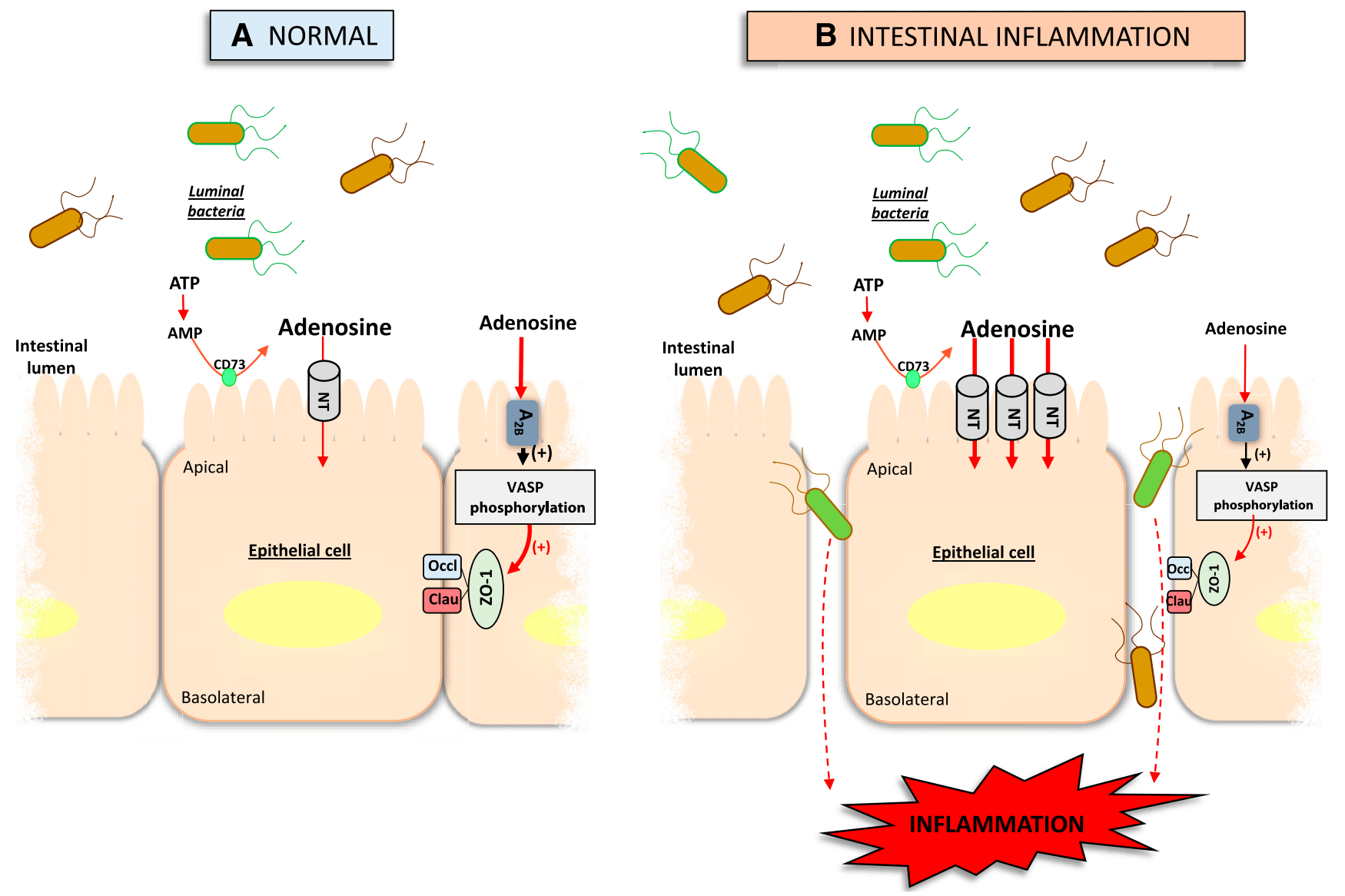

Fig. 4. Schematic representation showing the involvement of adenosine metabolism in regulating the level of $A_{2 B}$ receptor activation, in normal conditions (A) and in the presence of inflammatory bowel diseases (IBDs) (B). CD73 produces adenosine, but its levels are decreased in IBD by increased uptake into epithelial cells through upregulated NTs. The stimulation of $\mathrm{A}_{2 \mathrm{~B}}$ receptors participates in maintaining the integrity of epithelial barrier by sustaining the phosphorylation of VASP and thus strengthening the expression of tight junction protein, such as ZO-1, Clau, and Occl. This process is impaired during IBD. AMP, adenosine monophosphate; Clau, claudin; NT, nucleoside transporter; Occl, occluding; VASP, vasodilatorstimulated phosphoprotein; ZO-1, zonulin-1.

manage patients with various IMIDs. One caveat is that in some cases, the available data regarding the role of the purinergic system in some aspects of IMID pathophysiology are based only on individual studies, and in this case it is not possible to have consolidated evidence or draw substantial conclusions. In addition, it is necessary to point out that there are also competing and sometimes contradictory actions of the role of the purinergic system in IMIDs. For example, conflicting evidence has been observed regarding $\mathrm{T}_{\text {eff }}$ cells. In particular, increases in $\mathrm{A}_{2 \mathrm{~A}}$ receptor expression were observed in $\mathrm{T}_{\text {eff }}$ cells from SLE and uveitis patients, whereas $\mathrm{A}_{2 \mathrm{~A}}$ receptor expression appears reduced in myasthenia gravis, psoriasis, and IBD (Fig. 5). In addition, CD73 expression on $\mathrm{T}_{\text {eff }}$ cells was increased in IBD and reduced in uveitis and SLE (Fig. 5). In some cases, increased CD73 and $\mathrm{A}_{2 \mathrm{~A}}$ receptor expression may have compensatory anti-inflammatory functions, while in other cases they may contribute to disease pathophysiology and progression.

Although many next-generation ligands acting on the purinergic system are both reasonably selective in vitro and display encouraging beneficial effects in in vivo preclinical models, once thrown into the clinical arena their efficacy has turned out to be less than optimal. $\mathrm{P}_{2} \mathrm{X}_{7}$ receptor antagonists are a prime example of this. When novel and safe $\mathrm{P}_{2} \mathrm{X}_{7}$ receptor antagonists that have been shown to be effective in experimental models of inflammation, such as EAE, IBDs, and rheumatoid arthritis, were tested in humans, the results of these clinical studies were disappointing [see (Keystone et al., 2012; Stock et al., 2012; Eser et al., 2015)]. Although there is no definitive explanation for this lack of pharmacological efficacy in humans, one possibility is that the inefficient targeting of $\mathrm{P}_{2} \mathrm{X}_{7}$ receptors is caused by the high variation of $\mathrm{P}_{2} \mathrm{X}_{7}$ function among individuals, which is due to the numerous single nucleotide polymorphisms resulting in either loss- or gain-of-function (Sluyter and Stokes, 2011). For this reason, it will be of importance to determine the relative effectiveness of $\mathrm{P}_{2} \mathrm{X}_{7}$ therapeutics in relation to $\mathrm{P} 2 \mathrm{X}_{7}$ isoforms and polymorphic variants.

A novel theme in purinergic receptor research is receptor heteromers and coexpression. Indeed, heteromerization (the direct interaction between at least two different functional receptors forming a complex with 


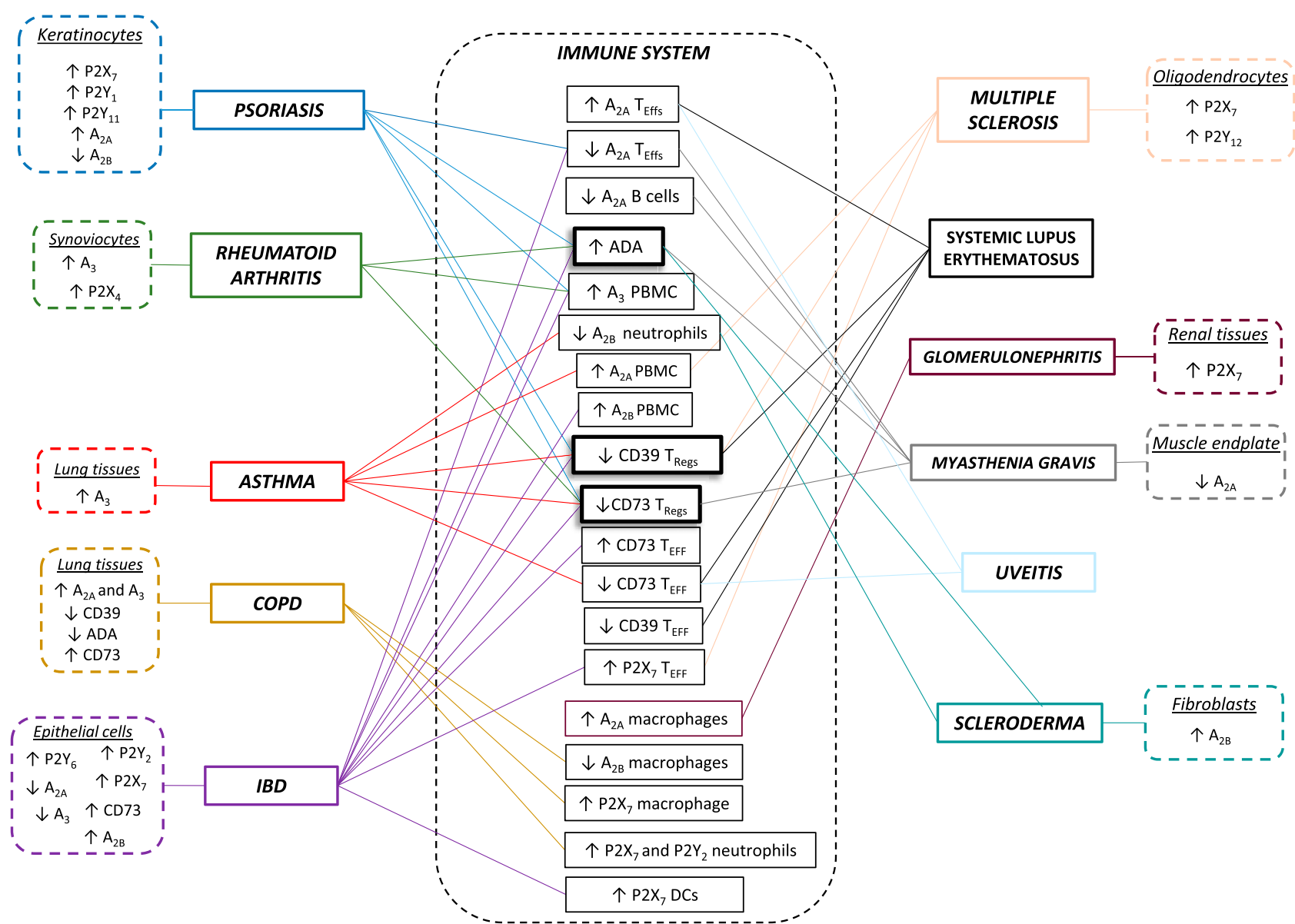

Fig. 5. Scheme illustrating the overlapping cellular alterations in components of the purinergic signaling complex in immune-mediated inflammatory diseases.

specific biochemical and functional properties different from those of its component receptor units) (Albizu et al., 2010 ) is emerging as an important process involved in the specialization of receptor function (Rozenfeld and Devi, 2010). This may be due to conformational changes in the heteromerized receptors within the receptorreceptor interface at the plane of the membrane bilayer or G-protein-mediated cooperativity in the plane of the membrane (Franco et al., 2008). Of note, the presence of receptor heteromers is reported in select tissues, and, in some cases, the heteromerization has been described to be involved in pathophysiological events (Franco et al., 2008). In this regard, $\mathrm{P}_{2} \mathrm{X}_{7}$ and $\mathrm{P} 2 \mathrm{X}_{4}$ are widely coexpressed, particularly in secretory epithelial cells and immune and inflammatory cells, and together participate in the regulation of inflammation and nociception (Schneider et al., 2017). There is also some evidence that $\mathrm{P}_{2} \mathrm{X}_{4}$ and $\mathrm{P} 2 \mathrm{X}_{7}$ can associate to form heteromeric receptors in some cell types under certain conditions (Guo et al., 2007). As these heteromers may have novel pharmacological profiles that differ from those of the constituting homomers, new drugs targeting the heteromers may have fewer side effects than drugs targeting the widely expressed homomers. The identification of crystal structures of $\mathrm{P} 2 \mathrm{X}_{3}, \mathrm{P}_{2} \mathrm{Y}_{2}$, or $\mathrm{P}_{2} \mathrm{Y}_{6}$ receptors (emerging as interesting molecular targets involved in shaping immune cell activity) may also help in better understanding the receptor function, fundamental signaling, thus paving the way toward the development of novel drugs potentially useful to counteract the inflammatory process. However, it is worth noting that there is still a long way to go in this field, since there is a paucity of studies on whether a given heteromer may form and become functional in the course of IMIDs.

In addition, another relevant aspect of purinergic pharmacology of IMIDs that deserves further study is the evaluation of how and to what extent drugs acting on purinergic signaling may have synergistic effects when administered together with other immunomodulatory agents. One study by Ochaion et al. (2006) reported a synergistic effect between methotrexate and CF101. Mechanistically, in a murine model of adjuvant-induced arthritis, methotrexate induced an increase in $\mathrm{A}_{3}$ receptor expression in inflamed tissues, thereby rendering the tissues more responsive to CF101 treatment (Ochaion et al., 2006).

In summary, given the pressing unmet medical need for novel pharmacological approaches for the management of IMIDs and the compelling data supporting the efficacy of targeting the purinergic system in preclinical 
models, the authors of this review hope that the purinergic system will be effectively targeted to manage human inflammatory diseases in the future.

\section{Authorship Contributions}

Wrote or contributed to the writing of the manuscript: Antonioli, Blandizzi, Pacher, Haskó.

\section{References}

Aherne CM, Collins CB, Rapp CR, Olli KE, Perrenoud L, Jedlicka P, Bowser JL, Mills TW, Karmouty-Quintana H, Blackburn MR, et al. (2018) Coordination of ENT2dependent adenosine transport and signaling dampens mucosal inflammation. JCI Insight 3: 121521.

Aherne CM, Saeedi B, Collins CB, Masterson JC, McNamee EN, Perrenoud L, Rapp CR, Curtis VF, Bayless A, Fletcher A, et al. (2015) Epithelial-specific A2B adenosine receptor signaling protects the colonic epithelial barrier during acute colitis. Mucosal Immunol 8:1324-1338.

Albizu L, Moreno JL, González-Maeso J, and Sealfon SC (2010) Heteromerization of $\mathrm{G}$ protein-coupled receptors: relevance to neurological disorders and neurotherapeutics. CNS Neurol Disord Drug Targets 9:636-650.

Aliagas E, Muñoz-Esquerre M, Cuevas E, Careta O, Huertas D, López-Sánchez M, Escobar I, Dorca J, and Santos S (2018) Is the purinergic pathway involved in the pathology of COPD? Decreased lung CD39 expression at initial stages of COPD. Respir Res 19:103.

Amadio S, Montilli C, Magliozzi R, Bernardi G, Reynolds R, and Volonté C (2010) $\mathrm{P} 2 \mathrm{Y} 12$ receptor protein in cortical gray matter lesions in multiple sclerosis. Cereb Cortex 20:1263-1273.

Amadio S, Parisi C, Piras E, Fabbrizio P, Apolloni S, Montilli C, Luchetti S, Ruggieri S, Gasperini C, Laghi-Pasini F, et al. (2017) Modulation of P2X7 receptor during inflammation in multiple sclerosis. Front Immunol 8:1529.

Amison RT, Momi S, Morris A, Manni G, Keir S, Gresele P, Page CP, and Pitchford $\mathrm{SC}$ (2015) RhoA signaling through platelet $\mathrm{P}_{2} \mathrm{Y}_{1}$ receptor controls leukocyte recruitment in allergic mice. J Allergy Clin Immunol 135:528-538.

Anders HJ (2013) Innate versus adaptive immunity in kidney immunopathology. BMC Nephrol 14:138.

Andrés RM, Terencio MC, Arasa J, Payá M, Valcuende-Cavero F, Navalón P, and Montesinos $\mathrm{MC}$ (2017) Adenosine $\mathrm{A}_{2 \mathrm{~A}}$ and $\mathrm{A}_{2 \mathrm{~B}}$ receptors differentially modulate keratinocyte proliferation: possible deregulation in psoriatic epidermis. J Invest Dermatol 137:123-131.

Antonioli L, Blandizzi C, Pacher P, and Haskó G (2013a) Immunity, inflammation and cancer: a leading role for adenosine. Nat Rev Cancer 13:842-857.

Antonioli L, Colucci R, La Motta C, Tuccori M, Awwad O, Da Settimo F, Blandizzi C, and Fornai M (2012) Adenosine deaminase in the modulation of immune system and its potential as a novel target for treatment of inflammatory disorders. Curr Drug Targets 13:842-862.

Antonioli L, Colucci R, Pellegrini C, Giustarini G, Tuccori M, Blandizzi C, and Fornai M (2013b) The role of purinergic pathways in the pathophysiology of gut diseases: pharmacological modulation and potential therapeutic applications. Pharmacol Ther 139:157-188

Antonioli L, El-Tayeb A, Pellegrini C, Fornai M, Awwad O, Giustarini G, Natale G, Ryskalin L, Németh ZH, Müller CE, et al. (2018) Anti-inflammatory effect of a novel locally acting $A_{2 A}$ receptor agonist in a rat model of oxazolone-induced colitis. Purinergic Signal 14:27-36.

Antonioli L, Fornai M, Awwad O, Giustarini G, Pellegrini C, Tuccori M, Caputi V, Qesari M, Castagliuolo I, Brun P, et al. (2014) Role of the A(2B) receptor-adenosine deaminase complex in colonic dysmotility associated with bowel inflammation in rats. Br J Pharmacol 171:1314-1329.

Antonioli L, Fornai M, Blandizzi C, Pacher P, and Hasko G (2019) Adenosine signaling and the immune system: when a lot could be too much. Immunol Lett 205:9-15.

Antonioli L, Fornai M, Colucci R, Awwad O, Ghisu N, Tuccori M, Da Settimo F, La Motta C, Natale G, Duranti E, et al. (2010a) The blockade of adenosine deaminase ameliorates chronic experimental colitis through the recruitment of adenosine A2A and A3 receptors. J Pharmacol Exp Ther 335:434-442.

Antonioli L, Fornai M, Colucci R, Awwad O, Ghisu N, Tuccori M, Del Tacca M, and Blandizzi C (2011) Differential recruitment of high affinity A1 and A2A adenosine receptors in the control of colonic neuromuscular function in experimental colitis. Eur J Pharmacol 650:639-649.

Antonioli L, Fornai M, Colucci R, Ghisu N, Blandizzi C, and Del Tacca M (2006) A2a receptors mediate inhibitory effects of adenosine on colonic motility in the presence of experimental colitis. Inflamm Bowel Dis 12:117-122.

Antonioli L, Fornai M, Colucci R, Ghisu N, Da Settimo F, Natale G, Kastsiuchenka O, Duranti E, Virdis A, Vassalle C, et al. (2007) Inhibition of adenosine deaminase attenuates inflammation in experimental colitis. J Pharmacol Exp Ther 322:435-442.

Antonioli L, Fornai M, Colucci R, Ghisu N, Tuccori M, Awwad O, Bin A, Zoppellaro C, Castagliuolo I, Gaion RM, et al. (2010b) Control of enteric neuromuscular functions by purinergic $\mathrm{A}(3)$ receptors in normal rat distal colon and experimental bowel inflammation. $\mathrm{Br} \mathrm{J}$ Pharmacol 161:856-871.

Antonioli L, Pacher P, Vizi ES, and Haskó G (2013c) CD39 and CD73 in immunity and inflammation. Trends Mol Med 19:355-367.

Apasov SG, Blackburn MR, Kellems RE, Smith PT, and Sitkovsky MV (2001) Adenosine deaminase deficiency increases thymic apoptosis and causes defective $\mathrm{T}$ cell receptor signaling. $J$ Clin Invest 108:131-141.

Arasa J, Martos P, Terencio MC, Valcuende-Cavero F, and Montesinos MC (2014) Topical application of the adenosine A2A receptor agonist CGS-21680 prevents phorbol-induced epidermal hyperplasia and inflammation in mice. Exp Dermatol 23:555-560.

Arulkumaran N, Turner CM, Sixma ML, Singer M, Unwin R, and Tam FW (2013) Purinergic signaling in inflammatory renal disease. Front Physiol 4:194.

Atarashi K, Nishimura J, Shima T, Umesaki Y, Yamamoto M, Onoue M, Yagita H, Ishii N, Evans R, Honda K, et al. (2008) ATP drives lamina propria T(H)17 cell differentiation. Nature 455:808-812.

Bahri R, Bollinger A, Bollinger T, Orinska Z, and Bulfone-Paus S (2012) Ectonucleotidase CD38 demarcates regulatory, memory-like CD8+ T cells with IFN- $\gamma$-mediated suppressor activities. PLoS One 7:e45234.

Bai A, Moss A, Kokkotou E, Usheva A, Sun X, Cheifetz A, Zheng Y, Longhi MS, Gao W, Wu Y, et al. (2014) CD39 and CD161 modulate Th17 responses in Crohn's disease. J Immunol 193:3366-3377.

Bai A, Moss A, Rothweiler S, Serena Longhi M, Wu Y, Junger WG, and Robson SC (2015) NADH oxidase-dependent CD39 expression by CD8(+) T cells modulates interferon gamma responses via generation of adenosine. Nat Commun 6:8819.

Bar-Yehuda S, Luger D, Ochaion A, Cohen S, Patokaa R, Zozulya G, Silver PB, de Morales JM, Caspi RR, and Fishman P (2011) Inhibition of experimental auto-immune uveitis by the A3 adenosine receptor agonist CF101. Int J Mol Med 28:727-731.

Bar-Yehuda S, Rath-Wolfson L, Del Valle L, Ochaion A, Cohen S, Patoka R, Zozulya G, Barer F, Atar E, Piña-Oviedo S, et al. (2009) Induction of an antiinflammatory effect and prevention of cartilage damage in rat knee osteoarthritis by CF101 treatment. Arthritis Rheum 60:3061-3071.

Barnes PJ (2013) Theophylline. Am J Respir Crit Care Med 188:901-906.

Barnes PJ (2018) Targeting cytokines to treat asthma and chronic obstructive pulmonary disease. Nat Rev Immunol 18:454-466.

Basoglu OK, Pelleg A, Essilfie-Quaye S, Brindicci C, Barnes PJ, and Kharitonov SA (2005) Effects of aerosolized adenosine $5^{\prime}$-triphosphate vs adenosine 5 '-monophosphate on dyspnea and airway caliber in healthy nonsmokers and patients with asthma. Chest 128:1905-1909.

Basu S, Barawkar DA, Ramdas V, Patel M, Waman Y, Panmand A, Kumar S, Thorat S, Naykodi M, Goswami A, et al. (2017a) Design and synthesis of novel xanthine derivatives as potent and selective $\mathrm{A}_{2 \mathrm{~B}}$ adenosine receptor antagonists for the treatment of chronic inflammatory airway diseases. Eur J Med Chem 134:218-229.

Basu S, Barawkar DA, Ramdas V, Waman Y, Patel M, Panmand A, Kumar S, Thorat S, Bonagiri R, Jadhav D, et al. (2017b) $A_{2 B}$ adenosine receptor antagonists: design, synthesis and biological evaluation of novel xanthine derivatives. Eur J Med Chem 127:986-996.

Bazzichi L, Trincavelli L, Rossi A, De Feo F, Lucacchini A, Bombardieri S, and Martini C (2005) A2B adenosine receptor activity is reduced in neutrophils from patients with systemic sclerosis. Arthritis Res Ther 7:R189-R195.

Beldi G, Wu Y, Banz Y, Nowak M, Miller L, Enjyoji K, Haschemi A, Yegutkin GG, Candinas D, Exley M, et al. (2008) Natural killer T cell dysfunction in CD39-null mice protects against concanavalin A-induced hepatitis. Hepatology 48:841-852

Bele T and Fabbretti E (2015) P2X receptors, sensory neurons and pain. Curr Med Chem 22:845-850.

Belikoff BG, Vaickus LJ, Sitkovsky M, and Remick DG (2012) A2B adenosine receptor expression by myeloid cells is proinflammatory in murine allergic-airway inflammation. J Immunol 189:3707-3713.

Berner B, Wolf G, Hummel KM, Müller GA, and Reuss-Borst MA (2000) Increased expression of CD40 ligand (CD154) on CD4+ T cells as a marker of disease activity in rheumatoid arthritis. Ann Rheum Dis 59:190-195.

Bidan CM, Veldsink AC, Meurs H, and Gosens R (2015) Airway and extracellular matrix mechanics in COPD. Front Physiol 6:346.

Blackburn MR, Lee CG, Young HW, Zhu Z, Chunn JL, Kang MJ, Banerjee SK, and Elias JA (2003) Adenosine mediates IL-13-induced inflammation and remodeling in the lung and interacts in an IL-13-adenosine amplification pathway. J Clin Invest 112:332-344.

Blackburn MR, Volmer JB, Thrasher JL, Zhong H, Crosby JR, Lee JJ, and Kellems $\mathrm{RE}$ (2000) Metabolic consequences of adenosine deaminase deficiency in mice are associated with defects in alveogenesis, pulmonary inflammation, and airway obstruction. J Exp Med 192:159-170.

Boirivant M, Fuss IJ, Chu A, and Strober W (1998) Oxazolone colitis: a murine model of T helper cell type 2 colitis treatable with antibodies to interleukin 4. J Exp Med 188:1929-1939.

Boldrini L, Giordano M, Alì G, Melfi F, Romano G, Lucchi M, and Fontanini G (2015) P2X7 mRNA expression in non-small cell lung cancer: microRNA regulation and prognostic value. Oncol Lett 9:449-453.

Bonneau O, Wyss D, Ferretti S, Blaydon C, Stevenson CS, and Trifilieff A (2006) Effect of adenosine A2A receptor activation in murine models of respiratory disorders. Am J Physiol Lung Cell Mol Physiol 290:L1036-L1043.

Bonnin N, Armandy E, Carras J, Ferrandon S, Battiston-Montagne P, Aubry M, Guihard S, Meyronet D, Foy JP, Saintigny P, et al. (2016) MiR-422a promotes locoregional recurrence by targeting NT5E/CD73 in head and neck squamous cell carcinoma. Oncotarget 7:44023-44038.

Borsellino G, Kleinewietfeld M, Di Mitri D, Sternjak A, Diamantini A, Giometto R, Höpner S, Centonze D, Bernardi G, Dell'Acqua ML, et al. (2007) Expression of ectonucleotidase CD39 by Foxp3+ Treg cells: hydrolysis of extracellular ATP and immune suppression. Blood 110:1225-1232.

Bortoluzzi A, Vincenzi F, Govoni M, Padovan M, Ravani A, Borea PA, and Varani K (2016) A2A adenosine receptor upregulation correlates with disease activity in patients with systemic lupus erythematosus. Arthritis Res Ther 18:192.

Boswell-Casteel RC and Hays FA (2017) Equilibrative nucleoside transporters-A review. Nucleosides Nucleotides Nucleic Acids 36:7-30.

Boyle DL, Sajjadi FG, and Firestein GS (1996) Inhibition of synoviocyte collagenase gene expression by adenosine receptor stimulation. Arthritis Rheum 39:923-930.

Brown JB, Lee G, Grimm GR, and Barrett TA (2008a) Therapeutic benefit of pentostatin in severe IL-10-/- colitis. Inflamm Bowel Dis 14:880-887.

Brown RA, Clarke GW, Ledbetter CL, Hurle MJ, Denyer JC, Simcock DE, Coote JE, Savage TJ, Murdoch RD, Page CP, et al. (2008b) Elevated expression of adenosine 
A1 receptor in bronchial biopsy specimens from asthmatic subjects. Eur Respir $J$ 31:311-319.

Burnstock G (2016) Short- and long-term (trophic) purinergic signalling. Philos Trans $R$ Soc Lond B Biol Sci 371:20150422.

Burnstock G (2017) Purinergic signaling in the cardiovascular system. Circ Res 120:207-228.

Burnstock G (2018) The therapeutic potential of purinergic signalling. Biochem Pharmacol 151:157-165.

Burnstock G and Boeynaems JM (2014) Purinergic signalling and immune cells. Purinergic Signal 10:529-564.

Burrell HE, Bowler WB, Gallagher JA, and Sharpe GR (2003) Human keratinocytes express multiple P2Y-receptors: evidence for functional P2Y1, P2Y2, and P2Y4 receptors. J Invest Dermatol 120:440-447.

Bynoe MS, Viret C, Yan A, and Kim DG (2015) Adenosine receptor signaling: a key to opening the blood-brain door. Fluids Barriers CNS 12:20.

Bynoe MS, Waickman AT, Mahamed DA, Mueller C, Mills JH, and Czopik A (2012) CD73 is critical for the resolution of murine colonic inflammation. J Biomed Biotechnol 2012:260983.

Cahenzli J, Balmer ML, and McCoy KD (2013) Microbial-immune cross-talk and regulation of the immune system. Immunology 138:12-22.

Camici M, Garcia-Gil M, and Tozzi MG (2018) The inside story of adenosine. Int $J$ Mol Sci 19:E784.

Capecchi PL, Rechichi S, Lazzerini PE, Collini A, Guideri F, Ruggieri G, Carmellini M, and Laghi-Pasini F (2005) Cyclosporin and tacrolimus increase plasma levels of adenosine in kidney transplanted patients. Transpl Int 18:289-295.

Caporali F, Capecchi PL, Gamberucci A, Lazzerini PE, Pompella G, Natale M, Lorenzini S, Selvi E, Galeazzi M, and Laghi Pasini F (2008) Human rheumatoid synoviocytes express functional P2X7 receptors. J Mol Med (Berl) 86:937-949.

Caragnano M, Tortorella P, Bergami A, Ruggieri M, Livrea P, Specchio LM, Martino G, Trojano M, Furlan R, and Avolio C (2012) Monocytes P2X7 purinergic receptor is modulated by glatiramer acetate in multiple sclerosis. J Neuroimmunol 245:93-97. Carman AJ, Mills JH, Krenz A, Kim DG, and Bynoe MS (2011) Adenosine receptor signaling modulates permeability of the blood-brain barrier. J Neurosci 31:13272-13280.

Caspi RR (2010) A look at autoimmunity and inflammation in the eye. J Clin Invest 120:3073-3083.

Cekic C and Linden J (2016) Purinergic regulation of the immune system. Nat Rev Immunol 16:177-192.

Cekic C, Sag D, Day YJ, and Linden J (2013) Extracellular adenosine regulates naive $\mathrm{T}$ cell development and peripheral maintenance. J Exp Med 210:2693-2706.

Chan ES, Fernandez P, Merchant AA, Montesinos MC, Trzaska S, Desai A, Tung CF, Khoa DN, Pillinger MH, Reiss AB, et al. (2006) Adenosine A2A receptors in diffuse dermal fibrosis: pathogenic role in human dermal fibroblasts and in a murine model of scleroderma. Arthritis Rheum 54:2632-2642.

Chan ES, Liu H, Fernandez P, Luna A, Perez-Aso M, Bujor AM, Trojanowska M, and Cronstein $\mathrm{BN}$ (2013) Adenosine $\mathrm{A}(2 \mathrm{~A})$ receptors promote collagen production by a Fli1- and CTGF-mediated mechanism. Arthritis Res Ther 15:R58.

Chen J, Chen YG, Reifsnyder PC, Schott WH, Lee CH, Osborne M, Scheuplein F, Haag F, Koch-Nolte F, Serreze DV, et al. (2006a) Targeted disruption of CD38 accelerates autoimmune diabetes in NOD/Lt mice by enhancing autoimmunity in an ADP-ribosyltransferase 2-dependent fashion. J Immunol 176:4590-4599.

Chen L and Brosnan CF (2006) Exacerbation of experimental autoimmune encephalomyelitis in P2X7R-/- mice: evidence for loss of apoptotic activity in lymphocytes. J Immunol 176:3115-3126.

Chen L, Deng H, Cui H, Fang J, Zuo Z, Deng J, Li Y, Wang X, and Zhao L (2017) Inflammatory responses and inflammation-associated diseases in organs. Oncotarget 9:7204-7218

Chen M, Liang D, Zuo A, Shao H, Kaplan HJ, and Sun D (2015) An A2B adenosine receptor agonist promotes Th17 autoimmune responses in experimental autoimmune uveitis (EAU) via dendritic cell activation. PLoS One 10:e0132348.

Chen M, Su W, Lin X, Guo Z, Wang J, Zhang Q, Brand D, Ryffel B, Huang J, Liu Z, et al. (2013) Adoptive transfer of human gingiva-derived mesenchymal stem cells ameliorates collagen-induced arthritis via suppression of Th1 and Th17 cells and enhancement of regulatory T cell differentiation. Arthritis Rheum 65:1181-1193.

Chen SC and Sheu SJ (2017) Recent advances in managing and understanding uveitis. F1000 Res 6:280.

Chen YG, Chen J, Osborne MA, Chapman HD, Besra GS, Porcelli SA, Leiter EH, Wilson SB, and Serreze DV (2006b) CD38 is required for the peripheral survival of immunotolerogenic CD4+ invariant NK T cells in nonobese diabetic mice. J Immunol 177:2939-2947.

Chiba S, Matsumoto H, Motoi Y, Miyano N, and Kashiwagi M (1990) High serum adenosine deaminase activity and its correlation with lymphocyte subsets in myasthenia gravis. $J$ Neurol Sci 100:174-177.

Chiba S, Saitoh M, Kashiwagi M, Kobayashi N, and Matsumoto H (1995) Isozyme analysis of the high serum adenosine deaminase activity in patients with myasthenia gravis. Intern Med 34:81-84.

Christopher AF, Kaur RP, Kaur G, Kaur A, Gupta V, and Bansal P (2016) MicroRNA therapeutics: discovering novel targets and developing specific therapy. Perspect Clin Res 7:68-74.

Chrobak P, Charlebois R, Rejtar P, El Bikai R, Allard B, and Stagg J (2015) CD73 plays a protective role in collagen-induced arthritis. J Immunol 194:2487-2492.

Churg A, Zhou S, and Wright JL (2012) Series "matrix metalloproteinases in lung health and disease": matrix metalloproteinases in COPD. Eur Respir J 39:197-209.

Cicko S, Lucattelli M, Müller T, Lommatzsch M, De Cunto G, Cardini S, Sundas W, Grimm M, Zeiser R, Dürk T, et al. (2010) Purinergic receptor inhibition prevents the development of smoke-induced lung injury and emphysema. J Immunol 185:688-697.

Coddou C, Stojilkovic SS, and Huidobro-Toro JP (2011) Allosteric modulation of ATPgated P2X receptor channels. Rev Neurosci 22:335-354.

Cohen S, Barer F, Itzhak I, Silverman MH, and Fishman P (2018) Inhibition of IL-17 and IL-23 in human keratinocytes by the $\mathrm{A}_{3}$ adenosine receptor agonist piclidenoson. J Immunol Res 2018:2310970.
Colgan SP, Eltzschig HK, Eckle T, and Thompson LF (2006) Physiological roles for ecto-5'-nucleotidase (CD73). Purinergic Signal 2:351-360.

Colgan SP, Fennimore B, and Ehrentraut SF (2013) Adenosine and gastrointestinal inflammation. J Mol Med (Berl) 91:157-164.

Colucci R, Fornai M, Tuccori M, Antonioli L, Pasqualetti G, Blandizzi C, and Del Tacca M (2007) Tolerability profiles of leukotriene receptor antagonists and longacting beta2-adrenoceptor agonists in combination with inhaled corticosteroids for treatment of asthma: a review. J Asthma 44:411-422

Constantinescu CS, Farooqi N, O’Brien K, and Gran B (2011) Experimental autoimmune encephalomyelitis (EAE) as a model for multiple sclerosis (MS). Br J Pharmacol 164:1079-1106.

Conti-Fine BM, Milani M, and Kaminski HJ (2006) Myasthenia gravis: past, present, and future. J Clin Invest 116:2843-2854.

Corciulo C, Lendhey M, Wilder T, Schoen H, Cornelissen AS, Chang G, Kennedy OD and Cronstein BN (2017) Endogenous adenosine maintains cartilage homeostasis and exogenous adenosine inhibits osteoarthritis progression. Nat Commun 8:15019.

Cronstein BM (2006a) Adenosine receptors and wound healing, revised. ScientificWorldJournal 6:984-991.

Cronstein BN (2006b) Going with the flow: methotrexate, adenosine, and blood flow. Ann Rheum Dis 65:421-422.

Cronstein BN, Montesinos MC, and Weissmann G (1999) Salicylates and sulfasalazine, but not glucocorticoids, inhibit leukocyte accumulation by an adenosinedependent mechanism that is independent of inhibition of prostaglandin synthesis and p105 of NFkappaB. Proc Natl Acad Sci USA 96:6377-6381.

Csóka B, Himer L, Selmeczy Z, Vizi ES, Pacher P, Ledent C, Deitch EA, Spolarics Z Németh $\mathrm{ZH}$, and Haskó G (2008) Adenosine A2A receptor activation inhibits $\mathrm{T}$ helper 1 and $\mathrm{T}$ helper 2 cell development and effector function. FASEB $J$ 22:3491-3499.

Csóka B, Koscsó B, Töro G, Kókai E, Virág L, Németh ZH, Pacher P, Bai P and Haskó G (2014) A2B adenosine receptors prevent insulin resistance by inhibiting adipose tissue inflammation via maintaining alternative macrophage activation. Diabetes 63:850-866.

Csóka B, Németh ZH, Rosenberger P, Eltzschig HK, Spolarics Z, Pacher P, Selmeczy Z, Koscsó B, Himer L, Vizi ES, et al. (2010) A2B adenosine receptors protect against sepsis-induced mortality by dampening excessive inflammation. J Immunol 185:542-550.

Csóka B, Németh ZH, Szabó I, Davies DL, Varga ZV, Pálóczi J, Falzoni S, Di Virgilio F, Muramatsu R, Yamashita T, et al. (2018) Macrophage P2X4 receptors augment bacterial killing and protect against sepsis. JCI Insight 3:e9431.

Csóka B, Németh ZH, Törő G, Idzko M, Zech A, Koscsó B, Spolarics Z, Antonioli L, Cseri K, Erdélyi K, et al. (2015a) Extracellular ATP protects against sepsis through macrophage P2X7 purinergic receptors by enhancing intracellular bacterial killing. FASEB J 29:3626-3637.

Csóka B, Németh ZH, Törő G, Koscsó B, Kókai E, Robson SC, Enjyoji K, Rolandelli RH, Erdélyi K, Pacher P, et al. (2015b) CD39 improves survival in microbial sepsis by attenuating systemic inflammation. FASEB J 29:25-36.

Csóka B, Selmeczy Z, Koscsó B, Németh ZH, Pacher P, Murray PJ, Kepka-Lenhart D, Morris SM Jr, Gause WC, Leibovich SJ, et al. (2012) Adenosine promotes alternative macrophage activation via $\mathrm{A} 2 \mathrm{~A}$ and $\mathrm{A} 2 \mathrm{~B}$ receptors. FASEB $J$ 26:376-386.

Cushley MJ, Tattersfield AE, and Holgate ST (1983) Inhaled adenosine and guanosine on airway resistance in normal and asthmatic subjects. $\mathrm{Br}$ J Clin Pharmacol 15:161-165.

Daheshia M (2005) Therapeutic inhibition of matrix metalloproteinases for the treatment of chronic obstructive pulmonary disease (COPD). Curr Med Res Opin 21:587-594.

Danquah W, Meyer-Schwesinger C, Rissiek B, Pinto C, Serracant-Prat A, Amadi M Iacenda D, Knop JH, Hammel A, Bergmann P, et al. (2016) Nanobodies that block gating of the P2X7 ion channel ameliorate inflammation. Sci Transl Med 8:366ra162.

Dargahi N, Katsara M, Tselios T, Androutsou ME, de Courten M, Matsoukas J, and Apostolopoulos V (2017) Multiple sclerosis: immunopathology and treatment update. Brain Sci 7:78.

David M, Gospodinov DK, Gheorghe N, Mateev GS, Rusinova MV, Hristakieva E, Solovastru LG, Patel RV, Giurcaneanu C, Hitova MC, et al. (2016) Treatment of plaque-type psoriasis with oral CF101: data from a phase II/III multicenter, randomized, controlled trial. J Drugs Dermatol 15:931-938.

David T, Ling SF, and Barton A (2018) Genetics of immune-mediated inflammatory diseases. Clin Exp Immunol 193:3-12.

Degagné E, Degrandmaison J, Grbic DM, Vinette V, Arguin G, and Gendron FP (2013) P2Y2 receptor promotes intestinal microtubule stabilization and mucosa re-epithelization in experimental colitis. J Cell Physiol 228:99-109.

De Marchi E, Orioli E, Dal Ben D, and Adinolfi E (2016) P2X7 receptor as a therapeutic target. Adv Protein Chem Struct Biol 104:39-79.

Demedts IK, Brusselle GG, Bracke KR, Vermaelen KY, and Pauwels RA (2005) Matrix metalloproteinases in asthma and COPD. Curr Opin Pharmacol 5:257-263. Denton CP and Khanna D (2017) Systemic sclerosis. Lancet 390:1685-1699.

Dixon CJ, Bowler WB, Littlewood-Evans A, Dillon JP, Bilbe G, Sharpe GR, and Gallagher JA (1999) Regulation of epidermal homeostasis through P2Y2 receptors. Br J Pharmacol 127:1680-1686.

Doherty GA, Bai A, Hanidziar D, Longhi MS, Lawlor GO, Putheti P, Csizmadia E, Nowak M, Cheifetz AS, Moss AC, et al. (2012) CD73 is a phenotypic marker of effector memory Th17 cells in inflammatory bowel disease. Eur J Immunol 42: 3062-3072

Dosch M, Gerber J, Jebbawi F, and Beldi G (2018) Mechanisms of ATP release by inflammatory cells. Int J Mol Sci 19:1222.

Dos Santos Jaques JA, Becker LV, Souza VdoC, Leal CA, Bertoldo TM, de Vargas Pinheiro K, Morsch VM, Schetinger MR, and Leal DB (2013) Activities of enzymes that hydrolyze adenine nucleotides in lymphocytes from patients with rheumatoid arthritis. Cell Biochem Funct 31:395-399.

Dowd E, McQueen DS, Chessell IP, and Humphrey PP (1998) P2X receptor-mediated excitation of nociceptive afferents in the normal and arthritic rat knee joint. $\mathrm{Br} J$ Pharmacol 125:341-346. 
Driver AG, Kukoly CA, Ali S, and Mustafa SJ (1993) Adenosine in bronchoalveolar lavage fluid in asthma. Am Rev Respir Dis 148:91-97.

Enjyoji K, Kotani K, Thukral C, Blumel B, Sun X, Wu Y, Imai M, Friedman D, Csizmadia E, Bleibel W, et al. (2008) Deletion of cd39/entpd1 results in hepatic insulin resistance. Diabetes 57:2311-2320.

Eser A, Colombel JF, Rutgeerts P, Vermeire S, Vogelsang H, Braddock M, Persson T, and Reinisch W (2015) Safety and efficacy of an oral inhibitor of the purinergic receptor P2X7 in adult patients with moderately to severely active Crohn's disease: a randomized placebo-controlled, double-blind, phase IIa study. Inflamm Bowel Dis 21:2247-2253.

Esther CR Jr, Lazaar AL, Bordonali E, Qaqish B, and Boucher RC (2011) Elevated airway purines in COPD. Chest 140:954-960.

Fan ZD, Zhang YY, Guo YH, Huang N, Ma HH, Huang H, and Yu HG (2016) Involvement of P2X7 receptor signaling on regulating the differentiation of Th17 cells and type II collagen-induced arthritis in mice. Sci Rep 6:35804.

Fernández P, Perez-Aso M, Smith G, Wilder T, Trzaska S, Chiriboga L, Franks A Jr, Robson SC, Cronstein BN, and Chan ESL (2013) Extracellular generation of adenosine by the ectonucleotidases CD39 and CD73 promotes dermal fibrosis. Am J Pathol 183:1740-1746.

Fernández P, Trzaska S, Wilder T, Chiriboga L, Blackburn MR, Cronstein BN, and Chan ES (2008) Pharmacological blockade of A2A receptors prevents dermal fibrosis in a model of elevated tissue adenosine. Am J Pathol 172:1675-1682.

Ferrari D, Bianchi N, Eltzschig HK, and Gambari R (2016) MicroRNAs modulate the purinergic signaling network. Trends Mol Med 22:905-918.

Ferreira MA, Jansen R, Willemsen G, Penninx B, Bain LM, Vicente CT, Revez JA Matheson MC, Hui J, Tung JY, et al.; Australian Asthma Genetics Consortium Collaborators (2017) Gene-based analysis of regulatory variants identifies 4 putative novel asthma risk genes related to nucleotide synthesis and signaling. J Allergy Clin Immunol 139:1148-1157.

Figliuolo VR, Savio LEB, Safya H, Nanini H, Bernardazzi C, Abalo A, de Souza HSP Kanellopoulos J, Bobe P, Coutinho CMLM, et al. (2017) P2X7 receptor promotes intestinal inflammation in chemically induced colitis and triggers death of mucosal regulatory T cells. Biochim Biophy Acta Mol Basis Dis 1863:1183-1194.

Fishman P, Bar-Yehuda S, Madi L, Rath-Wolfson L, Ochaion A, Cohen S, and Baharav E (2006) The PI3K-NF-kappaB signal transduction pathway is involved in mediating the anti-inflammatory effect of IB-MECA in adjuvantinduced arthritis. Arthritis Res Ther 8:R33.

Fletcher JM, Lonergan R, Costelloe L, Kinsella K, Moran B, O'Farrelly C, Tubridy N, and Mills KH (2009) CD39+Foxp3+ regulatory T Cells suppress pathogenic Th17 cells and are impaired in multiple sclerosis. J Immunol 183:7602-7610.

Flögel U, Burghoff S, van Lent PL, Temme S, Galbarz L, Ding Z, El-Tayeb A, Huels S, Bönner F, Borg N, et al. (2012) Selective activation of adenosine A2A receptors on immune cells by a CD73-dependent prodrug suppresses joint inflammation in experimental rheumatoid arthritis. Sci Transl Med 4:146ra108.

Forchap SL, Anandacoomarasamy A, Wicks J, Di Virgilio F, Baricordi OR, Rubini M, Trotta F, Wiley J, and Manolios N (2008) P2X7 gene polymorphisms do not appear to be a susceptibility gene locus in sporadic cases of systemic lupus erythematosus. Tissue Antigens 72:487-490.

Ford AP and Undem BJ (2013) The therapeutic promise of ATP antagonism at P2X3 receptors in respiratory and urological disorders. Front Cell Neurosci 7:267.

Foster HR, Fuerst E, Lee TH, Cousins DJ, and Woszczek G (2013) Characterisation of $\mathrm{P} 2 \mathrm{Y}(12)$ receptor responsiveness to cysteinyl leukotrienes. PLoS One 8:e58305.

Foster CJ, Prosser DM, Agans JM, Zhai Y, Smith MD, Lachowicz JE, Zhang FL, Gustafson E, Monsma FJ Jr, Wiekowski MT, et al. (2001) Molecular identification and characterization of the platelet ADP receptor targeted by thienopyridine antithrombotic drugs. J Clin Invest 107:1591-1598.

Franco R, Casadó V, Cortés A, Mallol J, Ciruela F, Ferré S, Lluis C, and Canela EI (2008) G-protein-coupled receptor heteromers: function and ligand pharmacology. Br J Pharmacol 153 (Suppl 1):S90-S98.

Franke H, Krügel U, and Illes P (2006) P2 receptors and neuronal injury. Pflugers Arch 452:622-644.

Fredholm BB, IJzerman AP, Jacobson KA, Linden J, and Müller CE (2011) International Union of Basic and Clinical Pharmacology. LXXXI. Nomenclature and classification of adenosine receptors--an update. Pharmacol Rev 63:1-34.

Frick JS, MacManus CF, Scully M, Glover LE, Eltzschig HK, and Colgan SP (2009) Contribution of adenosine A2B receptors to inflammatory parameters of experimental colitis. J Immunol 182:4957-4964.

Friedman B and Cronstein B (2018) Methotrexate mechanism in treatment of rheumatoid arthritis. Joint Bone Spine DOI: 10.1016/j.jbspin.2018.07.004 [published ahead of print].

Friedman DJ, Künzli BM, A-Rahim YI, Sevigny J, Berberat PO, Enjyoji K, Csizmadia E, Friess H, and Robson SC (2009) From the Cover: CD39 deletion exacerbates experimental murine colitis and human polymorphisms increase susceptibility to inflammatory bowel disease. Proc Natl Acad Sci U S A 106:16788-16793.

Fulzele S, El-Sherbini A, Ahmad S, Sangani R, Matragoon S, El-Remessy A Radhakrishnan R, and Liou GI (2015) MicroRNA-146b-3p regulates retinal inflammation by suppressing adenosine deaminase-2 in diabetes. BioMed Res Int 2015:846501.

Furuta Y, Tsai SH, Kinoshita M, Fujimoto K, Okumura R, Umemoto E, Kurashima Y, Kiyono H, Kayama H, and Takeda K (2017) E-NPP3 controls plasmacytoid dendritic cell numbers in the small intestine. PLoS One 12:e0172509.

Gabrielli A, Avvedimento EV, and Krieg T (2009) Scleroderma. N Engl J Med 360:1989-2003.

Garcia GE, Truong LD, Li P, Zhang P, Du J, Chen JF, and Feng L (2008) Adenosine $\mathrm{A} 2 \mathrm{~A}$ receptor activation and macrophage-mediated experimental glomerulonephritis. FASEB J 22:445-454.

Garzon R, Marcucci G, and Croce CM (2010) Targeting microRNAs in cancer: rationale, strategies and challenges. Nat Rev Drug Discov 9:775-789.

Gessi S, Varani K, Merighi S, Fogli E, Sacchetto V, Benini A, Leung E, Mac-Lennan $\mathrm{S}$, and Borea PA (2007) Adenosine and lymphocyte regulation. Purinergic Signal 3: 109-116.
Gibson DJ, Elliott L, McDermott E, Tosetto M, Keegan D, Byrne K, Martin ST, Rispens T, Cullen G, Mulcahy HE, et al. (2015) Heightened expression of CD39 by regulatory $\mathrm{T}$ lymphocytes is associated with therapeutic remission in inflammatory bowel disease. Inflamm Bowel Dis 21:2806-2814.

Göblyös A and Ijzerman AP (2011) Allosteric modulation of adenosine receptors. Biochim Biophys Acta 1808:1309-1318.

Grbic DM, Degagné E, Langlois C, Dupuis AA, and Gendron FP (2008) Intestinal inflammation increases the expression of the P2Y6 receptor on epithelial cells and the release of CXC chemokine ligand 8 by UDP. J Immunol 180:2659-2668.

Grbic DM, Degagné É, Larrivée JF, Bilodeau MS, Vinette V, Arguin G, Stankova J, and Gendron FP (2012) P2Y6 receptor contributes to neutrophil recruitment to inflamed intestinal mucosa by increasing CXC chemokine ligand 8 expression in an AP-1-dependent manner in epithelial cells. Inflamm Bowel Dis 18:1456-1469.

Guarner F and Malagelada JR (2003) Role of bacteria in experimental colitis. Best Pract Res Clin Gastroenterol 17:793-804.

Guo C, Masin M, Qureshi OS, and Murrell-Lagnado RD (2007) Evidence for functional P2X4/P2X7 heteromeric receptors. Mol Pharmacol 72:1447-1456.

Guo LH and Schluesener HJ (2005) Lesional accumulation of P2X(4) receptor(+) macrophages in rat CNS during experimental autoimmune encephalomyelitis. Neuroscience 134:199-205.

Gupta V, Katiyar S, Singh A, Misra R, and Aggarwal A (2018) CD39 positive regulatory $\mathrm{T}$ cell frequency as a biomarker of treatment response to methotrexate in rheumatoid arthritis. Int $J$ Rheum Dis 21:1548-1556.

Guzman J, Yu JG, Suntres Z, Bozarov A, Cooke H, Javed N, Auer H, Palatini J, Hassanain HH, Cardounel AJ, et al. (2006) ADOA3R as a therapeutic target in experimental colitis: proof by validated high-density oligonucleotide microarray analysis. Inflamm Bowel Dis 12:766-789.

Han L, Sugiyama H, Zhang Q, Yan K, Fang X, McCormick TS, Cooper KD, and Huang Q (2018) Phenotypical analysis of ectoenzymes CD39/CD73 and adenosine receptor $2 \mathrm{~A}$ in $\mathrm{CD} 4^{+} \mathrm{CD} 25^{\text {high }}$ Foxp $^{+}$regulatory T-cells in psoriasis. Australas J Dermatol 59:e31-e38.

Haskó G, Antonioli L, and Cronstein BN (2018) Adenosine metabolism, immunity and joint health. Biochem Pharmacol 151:307-313.

Haskó G and Cronstein BN (2004) Adenosine: an endogenous regulator of innate immunity. Trends Immunol 25:33-39.

Haskó G, Csóka B, Koscsó B, Chandra R, Pacher P, Thompson LF, Deitch EA, Spolarics Z, Virág L, Gergely P, et al. (2011) Ecto-5'-nucleotidase (CD73) decreases mortality and organ injury in sepsis. J Immunol 187:4256-4267.

Haskó G, Csóka B, Németh ZH, Vizi ES, and Pacher P (2009) A(2B) adenosine receptors in immunity and inflammation. Trends Immunol 30:263-270.

Haskó G, Kuhel DG, Chen JF, Schwarzschild MA, Deitch EA, Mabley JG, Marton A, and Szabó C (2000a) Adenosine inhibits IL-12 and TNF-[alpha] production via adenosine A2a receptor-dependent and independent mechanisms. FASEB J 14:2065-2074.

Haskó G, Kuhel DG, Németh ZH, Mabley JG, Stachlewitz RF, Virág L, Lohinai Z, Southan GJ, Salzman AL, and Szabó C (2000b) Inosine inhibits inflammatory cytokine production by a posttranscriptional mechanism and protects against endotoxin-induced shock. J Immunol 164:1013-1019.

Haskó G, Linden J, Cronstein B, and Pacher P (2008) Adenosine receptors: therapeutic aspects for inflammatory and immune diseases. Nat Rev Drug Discov 7:759-770.

Haskó G and Pacher P (2012) Regulation of macrophage function by adenosine. Arterioscler Thromb Vasc Biol 32:865-869.

Haskó G, Szabó C, Németh ZH, Kvetan V, Pastores SM, and Vizi ES (1996) Adenosine receptor agonists differentially regulate $\mathrm{IL}-10$, TNF-alpha, and nitric oxide production in RAW 264.7 macrophages and in endotoxemic mice. J Immunol 157:4634-4640.

Haskó G, Szabó C, Németh ZH, Salzman AL, and Vizi ES (1998) Suppression of IL-12 production by phosphodiesterase inhibition in murine endotoxemia is IL-10 independent. Eur J Immunol 28:468-472.

Herrath J, Chemin K, Albrecht I, Catrina AI, and Malmström V (2014) Surface expression of CD39 identifies an enriched Treg-cell subset in the rheumatic joint, which does not suppress IL-17A secretion. Eur J Immunol 44:2979-2989.

Heyn J, Ledderose C, Hinske LC, Limbeck E, Möhnle P, Lindner HA, and Kreth S (2012) Adenosine A2A receptor upregulation in human PMNs is controlled by miRNA-214, miRNA-15, and miRNA-16. Shock 37:156-163.

Himer L, Csóka B, Selmeczy Z, Koscsó B, Pócza T, Pacher P, Németh ZH, Deitch EA, Vizi ES, Cronstein BN, et al. (2010) Adenosine A2A receptor activation protects CD4+ T lymphocytes against activation-induced cell death. FASEB J 24:2631-2640.

Hofman P, Cherfils-Vicini J, Bazin M, Ilie M, Juhel T, Hébuterne X, Gilson E, Schmid-Alliana A, Boyer O, Adriouch S, et al. (2015) Genetic and pharmacological inactivation of the purinergic P2RX7 receptor dampens inflammation but in creases tumor incidence in a mouse model of colitis-associated cancer. Cancer Res 75:835-845.

Hohenstein B, Renk S, Lang K, Daniel C, Freund M, Léon C, Amann KU, Gachet C, and Hugo CP (2007) P2Y1 gene deficiency protects from renal disease progression and capillary rarefaction during passive crescentic glomerulonephritis. J Am Soc Nephrol 18:494-505.

Horenstein AL, Chillemi A, Zaccarello G, Bruzzone S, Quarona V, Zito A, Serra S, and Malavasi F (2013) A CD38/CD203a/CD73 ectoenzymatic pathway independent of CD39 drives a novel adenosinergic loop in human T lymphocytes. OncoImmunology 2:e26246.

Horenstein AL, Quarona V, Toscani D, Costa F, Chillemi A, Pistoia V, Giuliani N, and Malavasi F (2016) Adenosine generated in the bone marrow niche through a CD38-mediated pathway correlates with progression of human myeloma. Mol Med 22:694-704.

Hu X, Ran H, Dechang W, Yibing W, Yongqiang F, and Qiang L (2013) Absence of the adenosine $\mathrm{A}(2 \mathrm{~A})$ receptor attenuates hypertrophic scarring in mice. J Burn Care Res 34:e161-e167.

Huang S, Chen Y, Wu W, Ouyang N, Chen J, Li H, Liu X, Su F, Lin L, and Yao Y (2013) miR-150 promotes human breast cancer growth and malignant behavior by targeting the pro-apoptotic purinergic P2X7 receptor. PLoS One 8:e80707.

Huang Y and Chen Z (2016) Inflammatory bowel disease related innate immunity and adaptive immunity. Am J Transl Res 8:2490-2497. 
Huszár E, Vass G, Vizi E, Csoma Z, Barát E, Molnár Világos G, Herjavecz I, and Horváth I (2002) Adenosine in exhaled breath condensate in healthy volunteers and in patients with asthma. Eur Respir $J$ 20:1393-1398.

Idzko M, K Ayata C, Müller T, Dürk T, Grimm M, Baudiß K, Vieira RP, Cicko S, Boehlke C, Zech A, et al. (2013) Attenuated allergic airway inflammation in Cd39 null mice. Allergy 68:472-480.

Idzko M, Hammad H, van Nimwegen M, Kool M, Willart MA, Muskens F, Hoogsteden HC, Luttmann W, Ferrari D, Di Virgilio F, et al. (2007) Extracellular ATP triggers and maintains asthmatic airway inflammation by activating dendritic cells. Nat Med 13:913-919.

Ikeda Y, Tanji E, Makino N, Kawata S, and Furukawa T (2012) MicroRNAs associated with mitogen-activated protein kinase in human pancreatic cancer. $\mathrm{Mol}$ Cancer Res 10:259-269.

Inami A, Kiyono H, and Kurashima Y (2018) ATP as a pathophysiologic mediator of bacteria-host crosstalk in the gastrointestinal tract. Int J Mol Sci 19:2371.

Ingwersen J, Wingerath B, Graf J, Lepka K, Hofrichter M, Schröter F, Wedekind F, Bauer A, Schrader J, Hartung HP, et al. (2016) Dual roles of the adenosine A2a receptor in autoimmune neuroinflammation. J Neuroinflammation 13:48.

Inoue K, Denda M, Tozaki H, Fujishita K, Koizumi S, and Inoue K (2005) Characterization of multiple P2X receptors in cultured normal human epidermal keratinocytes. J Invest Dermatol 124:756-763.

Ishimaru M, Tsukimoto M, Harada H, and Kojima S (2013) Involvement of P2Y 11 receptor in IFN- $\gamma$-induced IL-6 production in human keratinocytes. Eur J Pharmacol 703:67-73.

Jakovljevic M, Lavrnja I, Bozic I, Savic D, Bjelobaba I, Pekovic S, Sévigny J, Nedeljkovic N, and Laketa D (2017) Down-regulation of NTPDase2 and ADPsensitive P2 purinoceptors correlate with severity of symptoms during experimental autoimmune encephalomyelitis. Front Cell Neurosci 11:333.

Jimenez-Mateos EM, Arribas-Blazquez M, Sanz-Rodriguez A, Concannon C, Olivos-Ore LA, Reschke CR, Mooney CM, Mooney C, Lugara E, Morgan J, et al. (2015) microRNA targeting of the P2X7 purinoceptor opposes a contralateral epileptogenic focus in the hippocampus. Sci Rep 5:17486.

Johnston JB, Silva C, Gonzalez G, Holden J, Warren KG, Metz LM, and Power C (2001) Diminished adenosine A1 receptor expression on macrophages in brain and blood of patients with multiple sclerosis. Ann Neurol 49:650-658.

Junger WG (2011) Immune cell regulation by autocrine purinergic signalling. Nat Rev Immunol 11:201-212.

Karmouty-Quintana H, Molina JG, Philip K, Bellocchi C, Gudenkauf B, Wu M, Chen NY, Collum SD, Ko J, Agarwal SK, et al. (2018) The antifibrotic effect of $\mathrm{A}_{2 \mathrm{~B}}$ adenosine receptor antagonism in a mouse model of dermal fibrosis. Arthritis Rheumatol 70:1673-1684.

Karmouty-Quintana H, Weng T, Garcia-Morales LJ, Chen NY, Pedroza M, Zhong H, Molina JG, Bunge R, Bruckner BA, Xia Y, et al (2013) Adenosine A2B receptor and hyaluronan modulate pulmonary hypertension associated with chronic obstructive pulmonary disease. Am J Respir Cell Mol Biol 49:1038-1047.

Keystone EC, Wang MM, Layton M, Hollis S, and McInnes IB; D1520C00001 Study Team (2012) Clinical evaluation of the efficacy of the P2X7 purinergic receptor antagonist AZD9056 on the signs and symptoms of rheumatoid arthritis in patients with active disease despite treatment with methotrexate or sulphasalazine. Ann Rheum Dis 71:1630-1635.

Killeen ME, Ferris L, Kupetsky EA, Falo L Jr, and Mathers AR (2013) Signaling through purinergic receptors for ATP induces human cutaneous innate and adaptive Th17 responses: implications in the pathogenesis of psoriasis. J Immunol 190:4324-4336

Kim DG and Bynoe MS (2015) A2A adenosine receptor regulates the human bloodbrain barrier permeability. Mol Neurobiol 52:664-678.

Kitching AR and Hutton HL (2016) The players: cells involved in glomerular disease. Clin J Am Soc Nephrol 11:1664-1674.

Klein K, Aeschlimann A, Jordan S, Gay R, Gay S, and Sprott H (2012) ATP induced brain-derived neurotrophic factor expression and release from osteoarthritis synovial fibroblasts is mediated by purinergic receptor P2X4. PLoS One 7:e36693.

Knight JS, Mazza LF, Yalavarthi S, Sule G, Ali RA, Hodgin JB, Kanthi Y, and Pinsky DJ (2018) Ectonucleotidase-mediated suppression of lupus autoimmunity and vascular dysfunction. Front Immunol 9:1322.

Koizumi H, Arito M, Endo W, Kurokawa MS, Okamoto K, Omoteyama K, Suematsu N, Beppu M, and Kato T (2015) Effects of tofacitinib on nucleic acid metabolism in human articular chondrocytes. Mod Rheumatol 25:522-527.

Kolachala V, Asamoah V, Wang L, Obertone TS, Ziegler TR, Merlin D, and Sitaraman SV (2005) TNF-alpha upregulates adenosine $2 \mathrm{~b}(\mathrm{~A} 2 \mathrm{~b})$ receptor expression and signaling in intestinal epithelial cells: a basis for A2bR overexpression in colitis. Cell Mol Life Sci 62:2647-2657.

Kolachala V, Ruble B, Vijay-Kumar M, Wang L, Mwangi S, Figler H, Figler R, Srinivasan S, Gewirtz A, Linden J, et al. (2008a) Blockade of adenosine A2B receptors ameliorates murine colitis. Br J Pharmacol 155:127-137.

Kolachala VL, Vijay-Kumar M, Dalmasso G, Yang D, Linden J, Wang L, Gewirtz A, Ravid K, Merlin D, and Sitaraman SV (2008b) A2B adenosine receptor gene deletion attenuates murine colitis. Gastroenterology 135:861-870.

Kolachala VL, Wang L, Obertone TS, Prasad M, Yan Y, Dalmasso G, Gewirtz AT, Merlin D, and Sitaraman SV (2010) Adenosine 2B receptor expression is posttranscriptionally regulated by microRNA. J Biol Chem 285:18184-18190.

Koscsó B, Csóka B, Kókai E, Németh ZH, Pacher P, Virág L, Leibovich SJ, and Haskó G (2013) Adenosine augments IL-10-induced STAT3 signaling in M2c macrophages. $J$ Leukoc Biol 94:1309-1315.

Koszalka P, Ozüyaman B, Huo Y, Zernecke A, Flögel U, Braun N, Buchheiser A, Decking UK, Smith ML, Sévigny J, et al. (2004) Targeted disruption of cd73/ecto5 '-nucleotidase alters thromboregulation and augments vascular inflammatory response. Circ Res 95:814-821.

Künzli BM, Berberat PO, Dwyer K, Deaglio S, Csizmadia E, Cowan P, d'Apice A Moore G, Enjyoji K, Friess H, et al. (2011) Variable impact of CD39 in experimental murine colitis. Dig Dis Sci 56:1393-1403.
Kurashima Y, Amiya T, Nochi T, Fujisawa K, Haraguchi T, Iba H, Tsutsui H, Sato S, Nakajima S, Iijima H, et al. (2012) Extracellular ATP mediates mast cell-dependent intestinal inflammation through P2X7 purinoceptors. Nat Commun 3:1034.

Kurashima Y, Kiyono H, and Kunisawa J (2015) Pathophysiological role of extracellular purinergic mediators in the control of intestinal inflammation. Mediators Inflamm 2015:427125.

La Motta C, Sartini S, Mugnaini L, Salerno S, Simorini F, Taliani S, Marini AM, Da Settimo F, Lavecchia A, Novellino E, et al. (2009) Exploiting the pyrazolo[3,4d]pyrimidin-4-one ring system as a useful template to obtain potent adenosine deaminase inhibitors. $J$ Med Chem 52:1681-1692.

Lanis JM, Kao DJ, Alexeev EE, and Colgan SP (2017) Tissue metabolism and the inflammatory bowel diseases. $J \mathrm{Mol} \mathrm{Med} \mathrm{(Berl)} \mathrm{95:905-913.}$

Lazar Z, Müllner N, Lucattelli M, Ayata CK, Cicko S, Yegutkin GG, De Cunto G, Müller T, Meyer A, Hossfeld M, et al. (2016) NTPDase1/CD39 and aberrant purinergic signalling in the pathogenesis of COPD. Eur Respir $J$ 47:254-263.

Lee DJ, Preble J, Lee S, Foster CS, and Taylor AW (2016) MC5r and A2Ar deficiencies during experimental autoimmune uveitis identifies distinct $\mathrm{T}$ cell polarization programs and a biphasic regulatory response. Sci Rep 6:37790.

Lee DJ and Taylor AW (2013) Both MC5r and A2Ar are required for protective regulatory immunity in the spleen of post-experimental autoimmune uveitis in mice. J Immunol 191:4103-4111.

Le Gall SM, Legrand J, Benbijja M, Safya H, Benihoud K, Kanellopoulos JM, and Bobé P (2012) Loss of P2X7 receptor plasma membrane expression and function in pathogenic B220+ double-negative T lymphocytes of autoimmune MRL/lpr mice. PLoS One 7:e52161.

Léon C, Hechler B, Freund M, Eckly A, Vial C, Ohlmann P, Dierich A, LeMeur M, Cazenave JP, and Gachet C (1999) Defective platelet aggregation and increased resistance to thrombosis in purinergic $\mathrm{P} 2 \mathrm{Y}(1)$ receptor-null mice. J Clin Invest 104: 1731-1737.

Li F, Guo N, Ma Y, Ning B, Wang Y, and Kou L (2014) Inhibition of P2X4 suppresses joint inflammation and damage in collagen-induced arthritis. Inflammation 37:146-153.

Li N, Mu L, Wang J, Zhang J, Xie X, Kong Q, Tang W, Yao X, Liu Y, Wang L, et al. (2012) Activation of the adenosine A2A receptor attenuates experimental autoimmune myasthenia gravis severity. Eur J Immunol 42:1140-1151.

Liang D, Zuo A, Shao H, Born WK, O'Brien RL, Kaplan HJ, and Sun D (2012) Role of CD25+ dendritic cells in the generation of Th17 autoreactive T cells in autoimmune experimental uveitis. J Immunol 188:5785-5791.

Liang D, Zuo A, Shao H, Chen M, Kaplan HJ, and Sun D (2014) Anti-inflammatory or proinflammatory effect of an adenosine receptor agonist on the Th17 autoimmune response is inflammatory environment-dependent. J Immunol 193:5498-5505.

Liang D, Zuo A, Shao H, Chen M, Kaplan HJ, and Sun D (2015) A2B adenosine receptor activation switches differentiation of bone marrow cells to a CD11c(+)Gr-1(+) dendritic cell subset that promotes the Th17 response. Immun Inflamm Dis 3:360-373.

Liang D, Zuo A, Zhao R, Shao H, Born WK, O'Brien RL, Kaplan HJ, and Sun D (2016a) CD73 expressed on $\gamma \delta \mathrm{T}$ cells shapes their regulatory effect in experimental autoimmune uveitis. PLoS One 11:e0150078.

Liang D, Zuo A, Zhao R, Shao H, Kaplan HJ, and Sun D (2016b) Regulation of adenosine deaminase on induced mouse experimental autoimmune uveitis. $J$ Immunol 196:2646-2654.

Liu J, Shi K, Chen M, Xu L, Hong J, Hu B, Yang X, and Sun R (2015) Elevated miR-155 expression induces immunosuppression via CD39(+) regulatory T-cells in sepsis patient. Int $J$ Infect Dis 40:135-141.

Liu Y, Alahiri M, Ulloa B, Xie B, and Sadiq SA (2018) Adenosine A2A receptor agonist ameliorates EAE and correlates with Th1 cytokine-induced blood brain barrier dysfunction via suppression of MLCK signaling pathway. Immun Inflamm Dis 6:72-80.

Liu Y, Zou H, Zhao P, Sun B, Wang J, Kong Q, Mu L, Zhao S, Wang G, Wang D, et al. (2016) Activation of the adenosine A2A receptor attenuates experimental autoimmune encephalomyelitis and is associated with increased intracellular calcium levels. Neuroscience 330:150-161.

Liu YC and Chun J (2018) Prospects for precision medicine in glomerulonephritis treatment. Can J Kidney Health Dis 5:2054358117753617.

Lommatzsch M, Cicko S, Müller T, Lucattelli M, Bratke K, Stoll P, Grimm M, Dürk T, Zissel G, Ferrari D, et al. (2010) Extracellular adenosine triphosphate and chronic obstructive pulmonary disease. Am J Respir Crit Care Med 181:928-934.

Longhi MS, Robson SC, Bernstein SH, Serra S, and Deaglio S (2013) Biological functions of ecto-enzymes in regulating extracellular adenosine levels in neoplastic and inflammatory disease states. J Mol Med (Berl) 91:165-172.

Longhi MS, Vuerich M, Kalbasi A, Kenison JE, Yeste A, Csizmadia E, Vaughn B, Feldbrugge L, Mitsuhashi S, Wegiel B, et al. (2017) Bilirubin suppresses Th17 immunity in colitis by upregulating CD39. JCI Insight 2:e92791.

Louis NA, Robinson AM, MacManus CF, Karhausen J, Scully M, and Colgan SP (2008) Control of IFN-alphaA by CD73: implications for mucosal inflammation. Immunol 180:4246-4255.

Lowes MA, Suárez-Fariñas M, and Krueger JG (2014) Immunology of psoriasis. Annu Rev Immunol 32:227-255.

Loza MJ, Anderson AS, O'Rourke KS, Wood J, and Khan IU (2011) T-cell specific defect in expression of the NTPDase CD39 as a biomarker for lupus. Cell Immunol 271:110-117.

Lucattelli M, Cicko S, Müller T, Lommatzsch M, De Cunto G, Cardini S, Sundas W, Grimm M, Zeiser R, Dürk T, et al. (2011) P2X7 receptor signaling in the pathogenesis of smoke-induced lung inflammation and emphysema. Am $J$ Respir Cell Mol Biol 44:423-429.

Luijk B, van den Berge M, Kerstjens HA, Postma DS, Cass L, Sabin A, and Lammers JW (2008) Effect of an inhaled adenosine A2A agonist on the allergen-induced late asthmatic response. Allergy 63:75-80.

Mabley J, Soriano F, Pacher P, Haskó G, Marton A, Wallace R, Salzman A, and Szabó C (2003) The adenosine A3 receptor agonist, N6-(3-iodobenzyl)-adenosine-5' $-\mathrm{N}$ methyluronamide, is protective in two murine models of colitis. Eur J Pharmacol 466:323-329. 
MacNee W and Tuder RM (2009) New paradigms in the pathogenesis of chronic obstructive pulmonary disease I. Proc Am Thorac Soc 6:527-531.

Madi L, Cohen S, Ochayin A, Bar-Yehuda S, Barer F, and Fishman P (2007) Overexpression of A3 adenosine receptor in peripheral blood mononuclear cells in rheumatoid arthritis: involvement of nuclear factor-kappaB in mediating receptor level. J Rheumatol 34:20-26.

Mandik-Nayak L, Seo SJ, Sokol C, Potts KM, Bui A, and Erikson J (1999) MRL-lpr/ lpr mice exhibit a defect in maintaining developmental arrest and follicular exclusion of anti-double-stranded DNA B cells. J Exp Med 189:1799-1814.

Mandler R, Birch RE, Polmar SH, Kammer GM, and Rudolph SA (1982) Abnormal adenosine-induced immunosuppression and cAMP metabolism in T lymphocytes of patients with systemic lupus erythematosus. Proc Natl Acad Sci USA 79:7542-7546.

Mantell SJ, Stephenson PT, Monaghan SM, Maw GN, Trevethick MA, Yeadon M, Keir RF, Walker DK, Jones RM, Selby MD, et al. (2008) Inhaled adenosine A(2A) receptor agonists for the treatment of chronic obstructive pulmonary disease. Bioorg Med Chem Lett 18:1284-1287.

Maor I, Rainis T, Lanir A, and Lavy A (2011) Adenosine deaminase activity in patients with Crohn's disease: distinction between active and nonactive disease. Eur J Gastroenterol Hepatol 23:598-602.

Marques CC, Castelo-Branco MT, Pacheco RG, Buongusto F, do Rosário A Jr, Schanaider A, Coutinho-Silva R, and de Souza HS (2014) Prophylactic systemic P2X7 receptor blockade prevents experimental colitis. Biochim Biophys Acta 1842:65-78.

Martini E, Krug SM, Siegmund B, Neurath MF, and Becker C (2017) Mend your fences: the epithelial barrier and its relationship with mucosal immunity in inflammatory bowel disease. Cell Mol Gastroenterol Hepatol 4:33-46.

Mascanfroni ID, Yeste A, Vieira SM, Burns EJ, Patel B, Sloma I, Wu Y, Mayo L, Ben-Hamo R, Efroni S, et al. (2013) IL-27 acts on DCs to suppress the T cell response and autoimmunity by inducing expression of the immunoregulatory molecule CD39. Nat Immunol 14:1054-1063.

Matute C, Torre I, Pérez-Cerdá F, Pérez-Samartín A, Alberdi E, Etxebarria E, Arranz AM, Ravid R, Rodríguez-Antigüedad A, Sánchez-Gómez M, et al. (2007) P2X(7) receptor blockade prevents ATP excitotoxicity in oligodendrocytes and ameliorates experimental autoimmune encephalomyelitis. J Neurosci 27:9525-9533.

McInnes IB, Cruwys S, Bowers K, and Braddock M (2014) Targeting the P2X7 receptor in rheumatoid arthritis: biological rationale for P2X7 antagonism. Clin Exp Rheumatol 32:878-882.

McInnes IB and Schett G (2011) The pathogenesis of rheumatoid arthritis. N Engl J Med 365:2205-2219.

Medzhitov R (2008) Origin and physiological roles of inflammation. Nature 454:428-435.

Meriggioli MN and Sanders DB (2012) Muscle autoantibodies in myasthenia gravis: beyond diagnosis? Expert Rev Clin Immunol 8:427-438.

Meunier P, Filipe P, Emerit I, Freitas J, Guerra Rodrigo F, and Manso C (1995) Adenosine deaminase in progressive systemic sclerosis. Acta Derm Venereol 75:297-299.

Mills JH, Alabanza LM, Mahamed DA, and Bynoe MS (2012a) Extracellular adenosine signaling induces CX3CL1 expression in the brain to promote experimental autoimmune encephalomyelitis. J Neuroinflammation 9:193.

Mills JH, Kim DG, Krenz A, Chen JF, and Bynoe MS (2012b) A2A adenosine receptor signaling in lymphocytes and the central nervous system regulates inflammation during experimental autoimmune encephalomyelitis. J Immunol 188:5713-5722.

Mills JH, Thompson LF, Mueller C, Waickman AT, Jalkanen S, Niemela J, Airas L, and Bynoe MS (2008) CD73 is required for efficient entry of lymphocytes into the central nervous system during experimental autoimmune encephalomyelitis. Proc Natl Acad Sci USA 105:9325-9330.

Mohsenin A, Mi T, Xia Y, Kellems RE, Chen JF, and Blackburn MR (2007) Genetic removal of the A2A adenosine receptor enhances pulmonary inflammation, mucin production, and angiogenesis in adenosine deaminase-deficient mice. Am J Physiol Lung Cell Mol Physiol 293:L753-L761.

Montesinos MC, Shaw JP, Yee H, Shamamian P, and Cronstein BN (2004) Adenosine $\mathrm{A}(2 \mathrm{~A})$ receptor activation promotes wound neovascularization by stimulating angiogenesis and vasculogenesis. Am J Pathol 164:1887-1892.

Montesinos MC, Takedachi M, Thompson LF, Wilder TF, Fernández P, and Cronstein BN (2007) The antiinflammatory mechanism of methotrexate depends on extracellular conversion of adenine nucleotides to adenosine by ecto-5'-nucleotidase: findings in a study of ecto-5'-nucleotidase gene-deficient mice. Arthritis Rheum 56:1440-1445.

Montesinos MC, Yap JS, Desai A, Posadas I, McCrary CT, and Cronstein BN (2000) Reversal of the antiinflammatory effects of methotrexate by the nonselective adenosine receptor antagonists theophylline and caffeine: evidence that the antiinflammatory effects of methotrexate are mediated via multiple adenosine receptors in rat adjuvant arthritis. Arthritis Rheum 43:656-663.

Morabito L, Montesinos MC, Schreibman DM, Balter L, Thompson LF, Resta R, Carlin G, Huie MA, and Cronstein BN (1998) Methotrexate and sulfasalazine promote adenosine release by a mechanism that requires ecto-5'-nucleotidasemediated conversion of adenine nucleotides. J Clin Invest 101:295-300.

Morra M, Zubiaur M, Terhorst C, Sancho J, and Malavasi F (1998) CD38 is functionally dependent on the TCR/CD3 complex in human T cells. FASEB $J$ 12:581-592.

Mortaz E, Folkerts G, Nijkamp FP, and Henricks PA (2010) ATP and the pathogenesis of COPD. Eur J Pharmacol 638:1-4.

Moulton VR, Suarez-Fueyo A, Meidan E, Li H, Mizui M, and Tsokos GC (2017) Pathogenesis of human systemic lupus erythematosus: a cellular perspective. Trends Mol Med 23:615-635.

Müller CE (2015) Medicinal chemistry of P2X receptors: allosteric modulators. Curr Med Chem 22:929-941.

Müller T, Robaye B, Vieira RP, Ferrari D, Grimm M, Jakob T, Martin SF, Di Virgilio F, Boeynaems JM, Virchow JC, et al. (2010) The purinergic receptor P2Y2 receptor mediates chemotaxis of dendritic cells and eosinophils in allergic lung inflammation. Allergy 65:1545-1553.
Müller T, Vieira RP, Grimm M, Dürk T, Cicko S, Zeiser R, Jakob T, Martin SF, Blumenthal B, Sorichter S, et al. (2011) A potential role for P2X7R in allergic airway inflammation in mice and humans. Am J Respir Cell Mol Biol 44:456-464.

Nadeem A, Fan M, Ansari HR, Ledent C, and Jamal Mustafa S (2007) Enhanced airway reactivity and inflammation in A2A adenosine receptor-deficient allergic mice. Am J Physiol Lung Cell Mol Physiol 292:L1335-L1344.

Naganuma M, Wiznerowicz EB, Lappas CM, Linden J, Worthington MT, and Ernst PB (2006) Cutting edge: critical role for A2A adenosine receptors in the T cellmediated regulation of colitis. J Immunol 177:2765-2769.

Nakamachi Y, Koshiba M, Nakazawa T, Hatachi S, Saura R, Kurosaka M, Kusaka H, and Kumagai S (2003) Specific increase in enzymatic activity of adenosine deaminase 1 in rheumatoid synovial fibroblasts. Arthritis Rheum 48:668-674.

Narcisse L, Scemes E, Zhao Y, Lee SC, and Brosnan CF (2005) The cytokine IL-1beta transiently enhances $\mathrm{P} 2 \mathrm{X} 7$ receptor expression and function in human astrocytes. Glia 49:245-258.

Németh ZH, Bleich D, Csóka B, Pacher P, Mabley JG, Himer L, Vizi ES, Deitch EA Szabó C, Cronstein BN, et al. (2007) Adenosine receptor activation ameliorates type 1 diabetes. FASEB J 21:2379-2388.

Németh ZH, Csóka B, Wilmanski J, Xu D, Lu Q, Ledent C, Deitch EA, Pacher P, Spolarics Z, and Haskó G (2006) Adenosine A2A receptor inactivation increases survival in polymicrobial sepsis. J Immunol 176:5616-5626.

Németh ZH, Lutz CS, Csóka B, Deitch EA, Leibovich SJ, Gause WC, Tone M, Pacher P, Vizi ES, and Haskó G (2005) Adenosine augments IL-10 production by macrophages through an A2B receptor-mediated posttranscriptional mechanism. $J$ Immunol 175:8260-8270.

Neurath MF (2014) Cytokines in inflammatory bowel disease. Nat Rev Immunol 14:329-342

Neves AR, Castelo-Branco MT, Figliuolo VR, Bernardazzi C, Buongusto F, Yoshimoto A Nanini HF, Coutinho CM, Carneiro A.J, Coutinho-Silva R, et al. (2014) Overexpression of ATP-activated P2X7 receptors in the intestinal mucosa is implicated in the pathogenesis of Crohn's disease. Inflamm Bowel Dis 20:444-457.

Obiefuna PC, Batra VK, Nadeem A, Borron P, Wilson CN, and Mustafa SJ (2005) A novel A1 adenosine receptor antagonist, L-97-1 [3-[2-(4-aminophenyl)-ethyl]-8-benzyl7-2-ethyl-(2-hydroxy-ethyl)-amino]-ethyl-1-propyl-3,7-dihydro-purine-2,6-dione], reduces allergic responses to house dust mite in an allergic rabbit model of asthma. J Pharmacol Exp Ther 315:329-336.

Ochaion A, Bar-Yehuda S, Cohen S, Amital H, Jacobson KA, Joshi BV, Gao ZG, Barer F, Patoka R, Del Valle L, et al. (2008) The A3 adenosine receptor agonist CF502 inhibits the PI3K, PKB/Akt and NF-kappaB signaling pathway in synoviocytes from rheumatoid arthritis patients and in adjuvant-induced arthritis rats. Biochem Pharmacol 76:482-494.

Ochaion A, Bar-Yehuda S, Cohen S, Barer F, Patoka R, Amital H, Reitblat T, Reitblat A Ophir J, Konfino I, et al. (2009) The anti-inflammatory target A(3) adenosine receptor is over-expressed in rheumatoid arthritis, psoriasis and Crohn's disease. Cell Immunol 258:115-122.

Ochaion A, Bar-Yehuda S, Cohn S, Del Valle L, Perez-Liz G, Madi L, Barer F, Farbstein M, Fishman-Furman S, Reitblat T, et al. (2006) Methotrexate enhances the anti-inflammatory effect of CF101 via up-regulation of the A3 adenosine receptor expression. Arthritis Res Ther 8:R169.

Odashima M, Bamias G, Rivera-Nieves J, Linden J, Nast CC, Moskaluk CA, Marini M, Sugawara K, Kozaiwa K, Otaka M, et al. (2005) Activation of A2A adenosine receptor attenuates intestinal inflammation in animal models of inflammatory bowel disease. Gastroenterology 129:26-33.

Oliveira L, Correia A, Cristina Costa A, Guerra-Gomes S, Ferreirinha F, MagalhãesCardoso MT, Vilanova M, and Correia-de-Sá P (2015) Deficits in endogenous adenosine formation by ecto-5'-nucleotidase/CD73 impair neuromuscular transmission and immune competence in experimental autoimmune myasthenia gravis. Mediators Inflamm 2015:460610.

Parisi C, Napoli G, Amadio S, Spalloni A, Apolloni S, Longone P, and Volonté C 2016) MicroRNA-125b regulates microglia activation and motor neuron death in ALS. Cell Death Differ 23:531-541.

Paruchuri S, Tashimo H, Feng C, Maekawa A, Xing W, Jiang Y, Kanaoka Y, Conley P, and Boyce JA (2009) Leukotriene E4-induced pulmonary inflammation is mediated by the P2Y12 receptor. J Exp Med 206:2543-2555.

Pastore S, Mascia F, Gulinelli S, Forchap S, Dattilo C, Adinolfi E, Girolomoni G, Di Virgilio F, and Ferrari D (2007) Stimulation of purinergic receptors modulates chemokine expression in human keratinocytes. J Invest Dermatol 127:660-667.

Pastor-Anglada M, Urtasun N, and Pérez-Torras S (2018) Intestinal nucleoside transporters: function, expression, and regulation. Compr Physiol 8:1003-1017.

Pawson AJ, Sharman JL, Benson HE, Faccenda E, Alexander SP, Buneman OP, Davenport AP, McGrath JC, Peters JA, Southan C, et al.; NC-IUPHAR (2014) The IUPHAR/BPS Guide to PHARMACOLOGY: an expert-driven knowledgebase of drug targets and their ligands. Nucleic Acids Res 42:D1098-D1106.

Pelleg A, Schulman ES, and Barnes PJ (2016) Extracellular adenosine 5'-triphosphate in Obstructive airway diseases. Chest 150:908-915.

Penberthy WT and Tsunoda I (2009) The importance of NAD in multiple sclerosis. Curr Pharm Des 15:64-99.

Peres RS, Liew FY, Talbot J, Carregaro V, Oliveira RD, Almeida SL, França RF, Donate PB, Pinto LG, Ferreira FI, et al. (2015) Low expression of CD39 on regulatory $\mathrm{T}$ cells as a biomarker for resistance to methotrexate therapy in rheumatoid arthritis. Proc Natl Acad Sci USA 112:2509-2514.

Perez-Aso M, Fernandez P, Mediero A, Chan ES, and Cronstein BN (2014) Adenosine $2 \mathrm{~A}$ receptor promotes collagen production by human fibroblasts via pathways involving cyclic AMP and AKT but independent of Smad2/3. FASEB $J$ 28:802-812.

Perruzza L, Gargari G, Proietti M, Fosso B, D’Erchia AM, Faliti CE, Rezzonico-Jost T, Scribano D, Mauri L, Colombo D, et al. (2017) T follicular helper cells promote a beneficial gut ecosystem for host metabolic homeostasis by sensing microbiotaderived extracellular ATP. Cell Rep 18:2566-2575.

Polachini CR, Spanevello RM, Casali EA, Zanini D, Pereira LB, Martins CC, Baldissareli J, Cardoso AM, Duarte MF, da Costa P, et al. (2014) Alterations in the cholinesterase 
and adenosine deaminase activities and inflammation biomarker levels in patients with multiple sclerosis. Neuroscience 266:266-274.

Polosa R (2002) Adenosine-receptor subtypes: their relevance to adenosine-mediated responses in asthma and chronic obstructive pulmonary disease. Eur Respir $J$ 20:488-496.

Polosa R and Blackburn MR (2009) Adenosine receptors as targets for therapeutic intervention in asthma and chronic obstructive pulmonary disease. Trends Pharmacol Sci 30:528-535.

Ponnoth DS, Nadeem A, Tilley S, and Mustafa SJ (2010) Involvement of A1 adenosine receptors in altered vascular responses and inflammation in an allergic mouse model of asthma. Am J Physiol Heart Circ Physiol 299:H81-H87.

Portales-Cervantes L, Niño-Moreno P, Doníz-Padilla L, Baranda-Candido L, GarcíaHernández M, Salgado-Bustamante M, González-Amaro R, and Portales-Pérez D (2010) Expression and function of the P2X(7) purinergic receptor in patients with systemic lupus erythematosus and rheumatoid arthritis. Hum Immunol 71:818-825.

Potocnik AJ, Kinne R, Menninger H, Zacher J, Emmrich F, and Kroczek RA (1990) Expression of activation antigens on $\mathrm{T}$ cells in rheumatoid arthritis patients. Scand J Immunol 31:213-224.

Proietti M, Cornacchione V, Rezzonico Jost T, Romagnani A, Faliti CE, Perruzza L, Rigoni R, Radaelli E, Caprioli F, Preziuso S, et al. (2014) ATP-gated ionotropic P2X7 receptor controls follicular T helper cell numbers in Peyer's patches to promote host-microbiota mutualism. Immunity 41:789-801.

Pupo AS, Duarte DA, Lima V, Teixeira LB, Parreiras-E-Silva LT, and Costa-Neto CM (2016) Recent updates on GPCR biased agonism. Pharmacol Res 112:49-57.

Qin C, Zhou J, Gao Y, Lai W, Yang C, Cai Y, Chen S, and Du C (2017) Critical role of $\mathrm{P} \mathrm{Y}_{12}$ receptor in regulation of Th17 differentiation and experimental autoimmune encephalomyelitis pathogenesis. J Immunol 199:72-81.

Quarona V, Zaccarello G, Chillemi A, Brunetti E, Singh VK, Ferrero E, Funaro A Horenstein AL, and Malavasi F (2013) CD38 and CD157: a long journey from activation markers to multifunctional molecules. Cytometry B Clin Cytom 84:207-217.

Qian S, Hoggatt A, Jones-Hall YL, Ware CF, Herring P, and Seye CI (2016) Deletion of P2Y2 receptor reveals a role for lymphotoxin- $\alpha$ in fatty streak formation. Vascul Pharmacol 85:11-20.

Rahimian R, Fakhfouri G, Daneshmand A, Mohammadi H, Bahremand A, Rasouli MR, Mousavizadeh K, and Dehpour AR (2010) Adenosine A2A receptors and uric acid mediate protective effects of inosine against TNBS-induced colitis in rats. Eur $J$ Pharmacol 649:376-381.

Ramanathan M, Luo W, Csóka B, Haskó G, Lukashev D, Sitkovsky MV, and Leibovich SJ (2009) Differential regulation of HIF-1alpha isoforms in murine macrophages by TLRA and adenosine $\mathrm{A}(2 \mathrm{~A})$ receptor agonists. J Leukoc Biol 86:681-689.

Rath-Wolfson L, Bar-Yehuda S, Madi L, Ochaion A, Cohen S, Zabutti A, and Fishman P (2006) IB-MECA, an A3 adenosine receptor agonist prevents bone resorption in rats with adjuvant induced arthritis. Clin Exp Rheumatol 24:400-406.

Ravani A, Vincenzi F, Bortoluzzi A, Padovan M, Pasquini S, Gessi S, Merighi S, Borea PA, Govoni M, and Varani K (2017) Role and function of $\mathrm{A}_{2 \mathrm{~A}}$ and $\mathrm{A}_{3}$ adenosine receptors in patients with ankylosing spondylitis, psoriatic arthritis and rheumatoid arthritis. Int J Mol Sci 18:697.

Read RW (2006) Uveitis: advances in understanding of pathogenesis and treatment. Curr Rheumatol Rep 8:260-266.

Ren T, Grants I, Alhaj M, McKiernan M, Jacobson M, Hassanain HH, Frankel W, Wunderlich J, and Christofi FL (2011) Impact of disrupting adenosine $\mathrm{A}_{3}$ receptors $\left(\mathrm{A}_{3}^{-} / /^{-} \mathrm{AR}\right)$ on colonic motility or progression of colitis in the mouse. Inflamm Bowel Dis 17:1698-1713.

Rissanen E, Virta JR, Paavilainen T, Tuisku J, Helin S, Luoto P, Parkkola R, Rinne JO, and Airas L (2013) Adenosine A2A receptors in secondary progressive multiple sclerosis: a [(11)C]TMSX brain PET study. J Cereb Blood Flow Metab 33:1394-1401.

Rönnblom L and Pascual V (2008) The innate immune system in SLE: type I interferons and dendritic cells. Lupus 17:394-399.

Rovina N, Koutsoukou A, and Koulouris NG (2013) Inflammation and immune response in COPD: where do we stand? Mediators Inflamm 2013:413735.

Rozenfeld R and Devi LA (2010) Receptor heteromerization and drug discovery. Trends Pharmacol Sci 31:124-130.

Rybaczyk L, Rozmiarek A, Circle K, Grants I, Needleman B, Wunderlich JE, Huang K and Christofi FL (2009) New bioinformatics approach to analyze gene expressions and signaling pathways reveals unique purine gene dysregulation profiles that distinguish between CD and UC. Inflamm Bowel Dis 15:971-984.

Saghiri R, Ghashghai N, Movaseghi S, Poursharifi P, Jalilfar S, Bidhendi MA Ghazizadeh L, and Ebrahimi-Rad M (2012) Serum adenosine deaminase activity in patients with systemic lupus erythematosus: a study based on ADA1 and ADA2 isoenzymes pattern. Rheumatol Int 32:1633-1638.

Sakaki H, Tsukimoto M, Harada H, Moriyama Y, and Kojima S (2013) Autocrine regulation of macrophage activation via exocytosis of ATP and activation of P2Y11 receptor. PLoS One 8:e59778.

Samuraki M, Sakai K, Odake Y, Yoshita M, Misaki K, Nakada M, and Yamada M (2017) Multiple sclerosis showing elevation of adenosine deaminase levels in the cerebrospinal fluid. Mult Scler Relat Disord 13:44-46.

Sasaki T and Nakajima H (1992) Serum adenosine deaminase activity in systemic sclerosis (scleroderma) and related disorders. J Am Acad Dermatol 27:411-414.

Scheibner KA, Boodoo S, Collins S, Black KE, Chan-Li Y, Zarek P, Powell JD, and Horton MR (2009) The adenosine a2a receptor inhibits matrix-induced inflammation in a novel fashion. Am J Respir Cell Mol Biol 40:251-259.

Schenk U, Frascoli M, Proietti M, Geffers R, Traggiai E, Buer J, Ricordi C, Westendorf AM, and Grassi F (2011) ATP inhibits the generation and function of regulatory T cells through the activation of purinergic P2X receptors. Sci Signal 4:ra12.

Schenk U, Westendorf AM, Radaelli E, Casati A, Ferro M, Fumagalli M, Verderio C, Buer J, Scanziani E, and Grassi F (2008) Purinergic control of T cell activation by ATP released through pannexin-1 hemichannels. Sci Signal 1:ra6.

Schneider M, Prudic K, Pippel A, Klapperstück M, Braam U, Müller CE, Schmalzing G, and Markwardt F (2017) Interaction of purinergic P2X4 and P2X7 receptor subunits. Front Pharmacol 8:860.

Scindia YM, Deshmukh US, and Bagavant H (2010) Mesangial pathology in glomerular disease: targets for therapeutic intervention. Adv Drug Deliv Rev 62:1337-1343.
Scrivo R, Vasile M, Bartosiewicz I, and Valesini G (2011) Inflammation as "common soil" of the multifactorial diseases. Autoimmun Rev 10:369-374.

Selmeczy Z, Csoka B, Pacher P, Vizi ES, and Hasko G (2007) The adenosine A2A receptor agonist CGS 21680 fails to ameliorate the course of dextran sulphateinduced colitis in mice. Inflamm Res 56:204-209.

Serhan CN and Levy BD (2018) Resolvins in inflammation: emergence of the pro-resolving superfamily of mediators. J Clin Invest 128:2657-2669.

Sévigny J, Martín-Satué M, and Pintor J (2015) Purinergic signalling in immune system regulation in health and disease. Mediators Inflamm 2015:106863.

Sharp AJ, Polak PE, Simonini V, Lin SX, Richardson JC, Bongarzone ER, and Feinstein DL (2008) P2x7 deficiency suppresses development of experimental autoimmune encephalomyelitis. $J$ Neuroinflammation 5:33

Silverman MH, Strand V, Markovits D, Nahir M, Reitblat T, Molad Y, Rosner I, Rozenbaum M, Mader R, Adawi M, et al. (2008) Clinical evidence for utilization of the A3 adenosine receptor as a target to treat rheumatoid arthritis: data from a phase II clinical trial. $J$ Rheumatol 35:41-48.

Sipka S (2011) Adenosine inhibits the release of arachidonic acid in activated human peripheral mononuclear cells. A proposed model for physiologic and pathologic regulation in systemic lupus erythematosus. ScientificWorldJournal 11:972-980.

Sluyter R and Stokes L (2011) Significance of P2X7 receptor variants to human health and disease. Recent Pat DNA Gene Seq 5:41-54.

Somers GR, Hammet FM, Trute L, Southey MC, and Venter DJ (1998) Expression of the P2Y6 purinergic receptor in human T cells infiltrating inflammatory bowel disease. Lab Invest 78:1375-1383.

Sotnikov I and Louis NA (2010) CD73-dependent regulation of interferon $\alpha \mathrm{A}$ and interleukin-10 in the inflamed mucosa. ScientificWorldJournal 10:2167-2180.

Spanevello RM, Mazzanti CM, Bagatini M, Correa M, Schmatz R, Stefanello N, Thomé G, Morsch VM, Becker L, Bellé L, et al. (2010a) Activities of the enzymes that hydrolyze adenine nucleotides in platelets from multiple sclerosis patients. $J$ Neurol 257:24-30.

Spanevello RM, Mazzanti CM, Schmatz R, Thomé G, Bagatini M, Correa M, Rosa C, Stefanello N, Bellé LP, Moretto MB, et al. (2010b) The activity and expression of NTPDase is altered in lymphocytes of multiple sclerosis patients. Clin Chim Acta 411:210-214.

Stock TC, Bloom BJ, Wei N, Ishaq S, Park W, Wang X, Gupta P, and Mebus CA (2012) Efficacy and safety of CE-224,535, an antagonist of P2X7 receptor, in treatment of patients with rheumatoid arthritis inadequately controlled by methotrexate. J Rheumatol 39:720-727.

Stolk JN, de Koning DG, Pennings AH, De Abreu RA, van de Putte LB, and Boerbooms AM (1999) Reduced purine 5'-nucleotidase activity in lymphocytes of patients with systemic lupus erythematosus: results of a pilot study. Ann Rheum Dis 58:122-125.

Sun CX, Young HW, Molina JG, Volmer JB, Schnermann J, and Blackburn MR (2005) A protective role for the A1 adenosine receptor in adenosine-dependent pulmonary injury. J Clin Invest 115:35-43.

Sun CX, Zhong H, Mohsenin A, Morschl E, Chunn JL, Molina JG, Belardinelli L, Zeng D, and Blackburn MR (2006) Role of A2B adenosine receptor signaling in adenosine-dependent pulmonary inflammation and injury. $J$ Clin Invest 116:2173-2182.

Suurväli J, Boudinot P, Kanellopoulos J, and Rüütel Boudinot S (2017) P2X4: a fast and sensitive purinergic receptor. Biomed $J$ 40:245-256.

Synnestvedt K, Furuta GT, Comerford KM, Louis N, Karhausen J, Eltzschig HK, Hansen KR, Thompson LF, and Colgan SP (2002) Ecto-5'-nucleotidase (CD73) regulation by hypoxia-inducible factor-1 mediates permeability changes in intestinal epithelia. J Clin Invest 110:993-1002

Szabó C, Scott GS, Virág L, Egnaczyk G, Salzman AL, Shanley TP, and Haskó G (1998) Suppression of macrophage inflammatory protein (MIP)-1alpha production and collagen-induced arthritis by adenosine receptor agonists. $\mathrm{Br} J$ Pharmacol 125:379-387.

Taruno A (2018) ATP release channels. Int J Mol Sci 19:808.

Taylor SR, Turner CM, Elliott JI, McDaid J, Hewitt R, Smith J, Pickering MC, Whitehouse DL, Cook HT, Burnstock G, et al. (2009) P2X7 deficiency attenuates renal injury in experimental glomerulonephritis. J Am Soc Nephrol 20:1275-1281.

Tian T, Zhou Y, Feng X, Ye S, Wang H, Wu W, Tan W, Yu C, Hu J, Zheng R, et al. (2016) MicroRNA-16 is putatively involved in the NF-кB pathway regulation in ulcerative colitis through adenosine A2a receptor (A2aAR) mRNA targeting. $S c i$ Rep 6:30824.

Trapp BD and Nave KA (2008) Multiple sclerosis: an immune or neurodegenerative disorder? Annu Rev Neurosci 31:247-269.

Trautmann A (2009) Extracellular ATP in the immune system: more than just a "danger signal". Sci Signal 2:pe6.

Truong LD, Trostel J, McMahan R, Chen JF, and Garcia GE (2016) Macrophage A2A adenosine receptors are essential to protect from progressive kidney injury. Am $J$ Pathol 186:2601-2613.

Tsai SH, Kinoshita M, Kusu T, Kayama H, Okumura R, Ikeda K, Shimada Y, Takeda A, Yoshikawa S, Obata-Ninomiya K, et al (2015) The ectoenzyme E-NPP3 negatively regulates ATP-dependent chronic allergic responses by basophils and mast cells. Immunity 42:279-293.

Tsutsui S, Schnermann J, Noorbakhsh F, Henry S, Yong VW, Winston BW, Warren K, and Power C (2004) A1 adenosine receptor upregulation and activation attenuates neuroinflammation and demyelination in a model of multiple sclerosis. $J$ Neurosci 24:1521-1529.

Turner CM, Tam FW, Lai PC, Tarzi RM, Burnstock G, Pusey CD, Cook HT, and Unwin RJ (2007) Increased expression of the pro-apoptotic ATP-sensitive P2X7 receptor in experimental and human glomerulonephritis. Nephrol Dial Transplant 22:386-395.

Turner JR (2009) Intestinal mucosal barrier function in health and disease. Nat Rev Immunol 9:799-809.

Turner MD, Nedjai B, Hurst T, and Pennington DJ (2014) Cytokines and chemokines: at the crossroads of cell signalling and inflammatory disease. Biochim Biophys Acta 1843:2563-2582.

Uratsuji H, Tada Y, Kawashima T, Kamata M, Hau CS, Asano Y, Sugaya M, Kadono T, Asahina A, Sato S, et al. (2012) P2Y6 receptor signaling pathway 
mediates inflammatory responses induced by monosodium urate crystals. $J$ Immunol 188:436-444.

Valadbeigi S, Saghiri R, Ebrahimi-Rad M, Khatami S, and Akhbari H (2019) Adenosine deaminase activity and HLA-DRB as diagnostic markers for rheumatoid arthritis. Curr Rheumatol Rev 15:44-49.

Vanderstocken G, Bondue B, Horckmans M, Di Pietrantonio L, Robaye B, Boeynaems JM, and Communi D (2010) P2Y2 receptor regulates VCAM-1 membrane and soluble forms and eosinophil accumulation during lung inflammation. J Immunol 185:3702-3707.

van Rooij E and Kauppinen S (2014) Development of microRNA therapeutics is coming of age. EMBO Mol Med 6:851-864.

Varani K, Caramori G, Vincenzi F, Adcock I, Casolari P, Leung E, Maclennan S, Gessi S, Morello S, Barnes PJ, et al. (2006) Alteration of adenosine receptors in patients with chronic obstructive pulmonary disease. Am J Respir Crit Care Med 173:398-406.

Varani K, Caramori G, Vincenzi F, Tosi A, Barczyk A, Contoli M, Casolari P, Triggiani M Hansel T, Leung E, et al. (2010) Oxidative/nitrosative stress selectively altered A(2B) adenosine receptors in chronic obstructive pulmonary disease. FASEB J 24:1192-1204.

Varani K, Massara A, Vincenzi F, Tosi A, Padovan M, Trotta F, and Borea PA (2009) Normalization of A2A and A3 adenosine receptor up-regulation in rheumatoid arthritis patients by treatment with anti-tumor necrosis factor alpha but not methotrexate. Arthritis Rheum 60:2880-2891.

Varani K, Padovan M, Vincenzi F, Targa M, Trotta F, Govoni M, and Borea PA (2011) $\mathrm{A} 2 \mathrm{~A}$ and $\mathrm{A} 3$ adenosine receptor expression in rheumatoid arthritis: upregulation, inverse correlation with disease activity score and suppression of inflammatory cytokine and metalloproteinase release. Arthritis Res Ther 13:R197.

Vázquez-Villoldo N, Domercq M, Martín A, Llop J, Gómez-Vallejo V, and Matute C (2014) P2X4 receptors control the fate and survival of activated microglia. Glia 62:171-184.

Veras FP, Peres RS, Saraiva AL, Pinto LG, Louzada-Junior P, Cunha TM, Paschoal JA, Cunha FQ, and Alves-Filho JC (2015) Fructose 1,6-bisphosphate, a high-energy intermediate of glycolysis, attenuates experimental arthritis by activating antiinflammatory adenosinergic pathway. Sci Rep 5:15171.

Versluis M, van den Berge M, Timens W, Luijk B, Rutgers B, Lammers JW, Postma DS, and Hylkema MN (2008) Allergen inhalation decreases adenosine receptor expression in sputum and blood of asthma patients. Allergy 63:1186-1194

Villar-Menéndez I, Porta S, Buira SP, Pereira-Veiga T, Díaz-Sánchez S, Albasanz JL, Ferrer I, Martín M, and Barrachina M (2014) Increased striatal adenosine A2A receptor levels is an early event in Parkinson's disease-related pathology and it is potentially regulated by miR-34b. Neurobiol Dis 69:206-214.

Vinapamula KS, Pemmaraju SV, Bhattaram SK, Bitla AR, and Manohar SM (2015) Serum adenosine deaminase as inflammatory marker in rheumatoid arthritis. $J$ Clin Diagn Res 9:BC08-BC10.

Vincenzi F, Corciulo C, Targa M, Merighi S, Gessi S, Casetta I, Gentile M, Granieri E, Borea PA, and Varani K (2013) Multiple sclerosis lymphocytes upregulate A2A adenosine receptors that are antiinflammatory when stimulated. Eur J Immunol 43:2206-2216.

Vivekanandhan S, Soundararajan CC, Tripathi M, and Maheshwari MC (2005) Adenosine deaminase and 5'nucleotidase activities in peripheral blood $\mathrm{T}$ cells of multiple sclerosis patients. Neurochem Res 30:453-456.

Vrolix K, Fraussen J, Molenaar PC, Losen M, Somers V, Stinissen P, De Baets MH, and Martínez-Martínez $\mathrm{P}(2010)$ The auto-antigen repertoire in myasthenia gravis. Autoimmunity 43:380-400.

Walker BA, Jacobson MA, Knight DA, Salvatore CA, Weir T, Zhou D, and Bai TR (1997) Adenosine A3 receptor expression and function in eosinophils. Am J Respir Cell Mol Biol 16:531-537.

Wan P, Liu X, Xiong Y, Ren Y, Chen J, Lu N, Guo Y, and Bai A (2016) Extracellular ATP mediates inflammatory responses in colitis via $\mathrm{P} 2 \times 7$ receptor signaling. $S c i$ Rep 6:19108.

Wang L, Wan H, Tang W, Ni Y, Hou X, Pan L, Song Y, and Shi G (2018a) Critical roles of adenosine A2A receptor in regulating the balance of Treg/Th17 cells in allergic asthma. Clin Respir J 12:149-157.

Wang LL, Tang HP, Shi GC, Wan HY, Tang W, Hou XX, Pan LN, Shi BY, and Tao LQ (2013) CD39/CD73 and the imbalance of Th17 cells and regulatory T cells in allergic asthma. Mol Med Rep 8:1432-1438.

Wang LL, Tang PH, Shi CG, Wan YH, Tang W, Hou XX, Pan NL, Shi YB, and Tao QL (2014a) Expression of CD39 mRNA is altered in the peripheral blood of patients with allergic asthma. Biomed Rep 2:75-78.

Wang N, Xiang X, Chen K, Liu P, and Zhu A (2018b) Targeting of NT5E by miR-30b and miR-340 attenuates proliferation, invasion and migration of gallbladder carcinoma. Biochimie 146:56-67.

Wang Y, Telesford KM, Ochoa-Repáraz J, Haque-Begum S, Christy M, Kasper EJ, Wang L, Wu Y, Robson SC, Kasper DL, et al. (2014b) An intestinal commensal symbiosis factor controls neuroinflammation via TLR2-mediated CD39 signalling. Nat Commun 5:4432.

Wei W, Du C, Lv J, Zhao G, Li Z, Wu Z, Haskó G, and Xie X (2013) Blocking A2B adenosine receptor alleviates pathogenesis of experimental autoimmune encephalomyelitis via inhibition of IL-6 production and Th17 differentiation. J Immunol 190:138-146.

Weyand CM, Fujii H, Shao L, and Goronzy JJ (2009) Rejuvenating the immune system in rheumatoid arthritis. Nat Rev Rheumatol 5:583-588.

Whitmore KV and Gaspar HB (2016) Adenosine deaminase deficiency - more than just an immunodeficiency. Front Immunol 7:314.

Wojtal KA, Eloranta JJ, Hruz P, Gutmann H, Drewe J, Staumann A, Beglinger C, Fried M, Kullak-Ublick GA, and Vavricka SR (2009) Changes in mRNA expression levels of solute carrier transporters in inflammatory bowel disease patients. Drug Metab Dispos 37:1871-1877.

Wright A, Mahaut-Smith M, Symon F, Sylvius N, Ran S, Bafadhel M, Muessel M, Bradding P, Wardlaw A, and Vial C (2016) Impaired P2X1 receptor-mediated adhesion in eosinophils from asthmatic patients. $J$ Immunol 196:4877-4884.
Wu W, He Y, Feng X, Ye S, Wang H, Tan W, Yu C, Hu J, Zheng R, and Zhou Y (2017) MicroRNA-206 is involved in the pathogenesis of ulcerative colitis via regulation of adenosine A3 receptor. Oncotarget 8:705-721.

Xie M, Qin H, Luo Q, Huang Q, He X, Yang Z, Lan P, and Lian L (2017) MicroRNA30 a regulates cell proliferation and tumor growth of colorectal cancer by targeting CD73. BMC Cancer 17:305.

Yang D, Chen H, Koupenova M, Carroll SH, Eliades A, Freedman JE, Toselli P, and Ravid $\mathrm{K}$ (2010) A new role for the A2b adenosine receptor in regulating platelet function. J Thromb Haemost 8:817-827.

Yang D, Zhang Y, Nguyen HG, Koupenova M, Chauhan AK, Makitalo M, Jones MR, St Hilaire C, Seldin DC, Toselli P, et al. (2006) The A2B adenosine receptor protects against inflammation and excessive vascular adhesion. $J$ Clin Invest 116:1913-1923.

Yegutkin GG (2008) Nucleotide- and nucleoside-converting ectoenzymes: important modulators of purinergic signalling cascade. Biochim Biophys Acta 1783:673-694

Yiangou Y, Facer P, Baecker PA, Ford AP, Knowles CH, Chan CL, Williams NS, and Anand P (2001) ATP-gated ion channel P2X(3) is increased in human inflammatory bowel disease. Neurogastroenterol Motil 13:365-369.

Yiangou Y, Facer P, Durrenberger P, Chessell IP, Naylor A, Bountra C, Banati RR, and Anand P (2006) COX-2, CB2 and P2X7-immunoreactivities are increased in activated microglial cells/macrophages of multiple sclerosis and amyotrophic lateral sclerosis spinal cord. BMC Neurol 6:12.

Young HW, Molina JG, Dimina D, Zhong H, Jacobson M, Chan LN, Chan TS, Lee JJ, and Blackburn MR (2004) A3 adenosine receptor signaling contributes to airway inflammation and mucus production in adenosine deaminase-deficient mice. $J$ Immunol 173:1380-1389.

Young HW, Sun CX, Evans CM, Dickey BF, and Blackburn MR (2006) A3 adenosine receptor signaling contributes to airway mucin secretion after allergen challenge. Am J Respir Cell Mol Biol 35:549-558.

Young JD (2016) The SLC28 (CNT) and SLC29 (ENT) nucleoside transporter families: a 30-year collaborative odyssey. Biochem Soc Trans 44:869-876.

Zabala A, Vazquez-Villoldo N, Rissiek B, Gejo J, Martin A, Palomino A, PerezSamartín A, Pulagam KR, Lukowiak M, Capetillo-Zarate E, et al. (2018) P2X4 receptor controls microglia activation and favors remyelination in autoimmune encephalitis. EMBO Mol Med 10: e8743.

Zaynagetdinov R, Ryzhov S, Goldstein AE, Yin H, Novitskiy SV, Goleniewska K, Polosukhin VV, Newcomb DC, Mitchell D, Morschl E, et al. (2010) Attenuation of chronic pulmonary inflammation in $\mathrm{A} 2 \mathrm{~B}$ adenosine receptor knockout mice. Am $J$ Respir Cell Mol Biol 42:564-571.

Zech A, Wiesler B, Ayata CK, Schlaich T, Dürk T, Hoßfeld M, Ehrat N, Cicko S, and Idzko M (2016) P2rx4 deficiency in mice alleviates allergen-induced airway inflammation. Oncotarget 7:80288-80297.

Zernecke A, Bidzhekov K, Ozüyaman B, Fraemohs L, Liehn EA, Lüscher-Firzlaff JM, Lüscher B, Schrader J, and Weber C (2006) CD73/ecto-5'-nucleotidase protects against vascular inflammation and neointima formation. Circulation 113: $2120-2127$.

Zhang F, Luo Y, Shao Z, Xu L, Liu X, Niu Y, Shi J, Sun X, Liu Y, Ding Y, et al. (2016) MicroRNA-187, a downstream effector of TGF $\beta$ pathway, suppresses Smadmediated epithelial-mesenchymal transition in colorectal cancer. Cancer Lett $\mathbf{3 7 3}$ : 203-213.

Zhang J, Corciulo C, Liu H, Wilder T, Ito M, and Cronstein B (2017a) Adenosine $\mathrm{A}_{2 \mathrm{a}}$ receptor blockade diminishes wnt/ $\beta$-catenin signaling in a murine model of bleomycin-induced dermal fibrosis. Am J Pathol 187:1935-1944.

Zhang J, Li Z, Hu X, Su Q, He C, Liu J, Ren H, Qian M, Liu J, Cui S, et al. (2017b) Knockout of $\mathrm{P}_{2} \mathrm{Y}_{12}$ aggravates experimental autoimmune encephalomyelitis in mice via increasing of IL-23 production and Th17 cell differentiation by dendritic cells. Brain Behav Immun 62:245-255.

Zhang L, Yang N, Wang S, Huang B, Li F, Tan H, Liang Y, Chen M, Li Y, and Yu X (2011) Adenosine $2 \mathrm{~A}$ receptor is protective against renal injury in $\mathrm{MRL} / \mathrm{lpr}$ mice. Lupus 20:667-677.

Zhao J, Wang H, Dai C, Wang H, Zhang H, Huang Y, Wang S, Gaskin F, Yang N, and Fu SM (2013) P2X7 blockade attenuates murine lupus nephritis by inhibiting activation of the NLRP3/ASC/caspase 1 pathway. Arthritis Rheum 65:3176-3185.

Zhao L, Liu YW, Yang T, Gan L, Yang N, Dai SS, and He F (2015) The mutual regulation between miR-214 and A2AR signaling plays an important role in inflammatory response. Cell Signal 27:2026-2034.

Zhao R, Liang D, and Sun D (2016) Blockade of extracellular ATP effect by oxidized ATP effectively mitigated induced mouse experimental autoimmune uveitis (EAU). PLoS One 11:e155953.

Zheng L, Zhang X, Yang F, Zhu J, Zhou P, Yu F, Hou L, Xiao L, He Q, and Wang B (2014) Regulation of the P2X7R by microRNA-216b in human breast cancer. Biochem Biophys Res Commun 452:197-204.

Zhou L, Qi X, Potashkin JA, Abdul-Karim FW, and Gorodeski GI (2008) MicroRNAs miR-186 and miR-150 down-regulate expression of the pro-apoptotic purinergic $\mathrm{P} 2 \mathrm{X} 7$ receptor by activation of instability sites at the 3 '-untranslated region of the gene that decrease steady-state levels of the transcript. J Biol Chem 283:28274-28286.

Zhou Y, Mohsenin A, Morschl E, Young HW, Molina JG, Ma W, Sun CX, MartinezValdez H, and Blackburn MR (2009) Enhanced airway inflammation and remodeling in adenosine deaminase-deficient mice lacking the A2B adenosine receptor. $J$ Immunol 182:8037-8046.

Zhou Y, Murthy JN, Zeng D, Belardinelli L, and Blackburn MR (2010) Alterations in adenosine metabolism and signaling in patients with chronic obstructive pulmonary disease and idiopathic pulmonary fibrosis. PLoS One 5:e9224.

Zhu Z, Homer RJ, Wang Z, Chen Q, Geba GP, Wang J, Zhang Y, and Elias JA (1999) Pulmonary expression of interleukin-13 causes inflammation, mucus hypersecretion, subepithelial fibrosis, physiologic abnormalities, and eotaxin production. $J$ Clin Invest 103:779-788. 